Prepared in cooperation with the Michigan Department of Environmental Quality

\title{
Analysis of Water-Quality Trends for Selected Streams in the Water Chemistry Monitoring Program, Michigan, 1998-2005
}

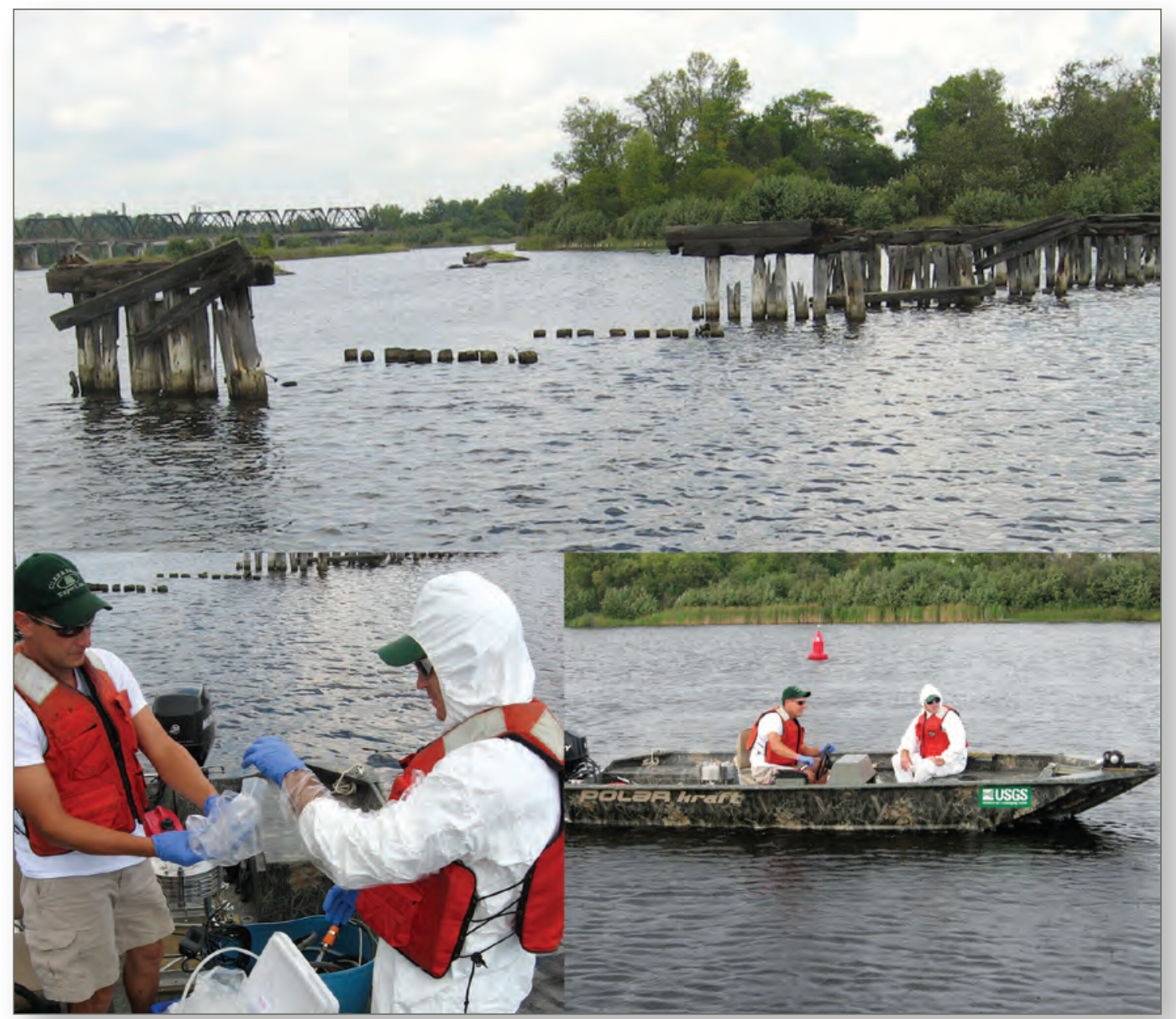

Scientific Investigations Report 2009-5216 



\section{Analysis of Water-Quality Trends for Selected Streams in the Water Chemistry Monitoring Program, Michigan, 1998-2005}

By C.J. Hoard, Lori M. Fuller, and Lisa R. Fogarty

Prepared in cooperation with the Michigan Department of Environmental Quality

Scientific Investigations Report 2009-5216 


\title{
U.S. Department of the Interior \\ KEN SALAZAR, Secretary \\ U.S. Geological Survey \\ Marcia K. McNutt, Director
}

\section{U.S. Geological Survey, Reston, Virginia: 2009}

\author{
For more information on the USGS — the Federal source for science about the Earth, its natural and living resources, \\ natural hazards, and the environment, visit http://www.usgs.gov or call 1-888-ASK-USGS \\ For an overview of USGS information products, including maps, imagery, and publications, \\ visit http://www.usgs.gov/pubprod \\ To order this and other USGS information products, visit http://store.usgs.gov
}

\begin{abstract}
Any use of trade, product, or firm names is for descriptive purposes only and does not imply endorsement by the U.S. Government.

Although this report is in the public domain, permission must be secured from the individual copyright owners to reproduce any copyrighted materials contained within this report.
\end{abstract}

Suggested citation:

Hoard, C.J., Fuller, L.M., and Fogarty, L.R., 2009, Analysis of water-quality trends for selected streams in the Water Chemistry Monitoring Program, Michigan, 1998-2005: U.S. Geological Survey Scientific Investigations Report 2009-5216, 48 p. 


\section{Acknowledgments}

The authors appreciate the helpful reviews from and discussions with Christine Aiello,

Dawn Roush, and Gary Kohlhepp from the Michigan Department of Environmental Quality.

The authors also wish to thank

- Tim Willoughby, and Tammy Zimmerman of the USGS who provided technical reviews of this report

- the many USGS hydrologic technicians who collected the data for this project, and

- Stephanie Beeler of the USGS, who assisted with use of the National Water Information System (NWIS) database. 



\section{Contents}

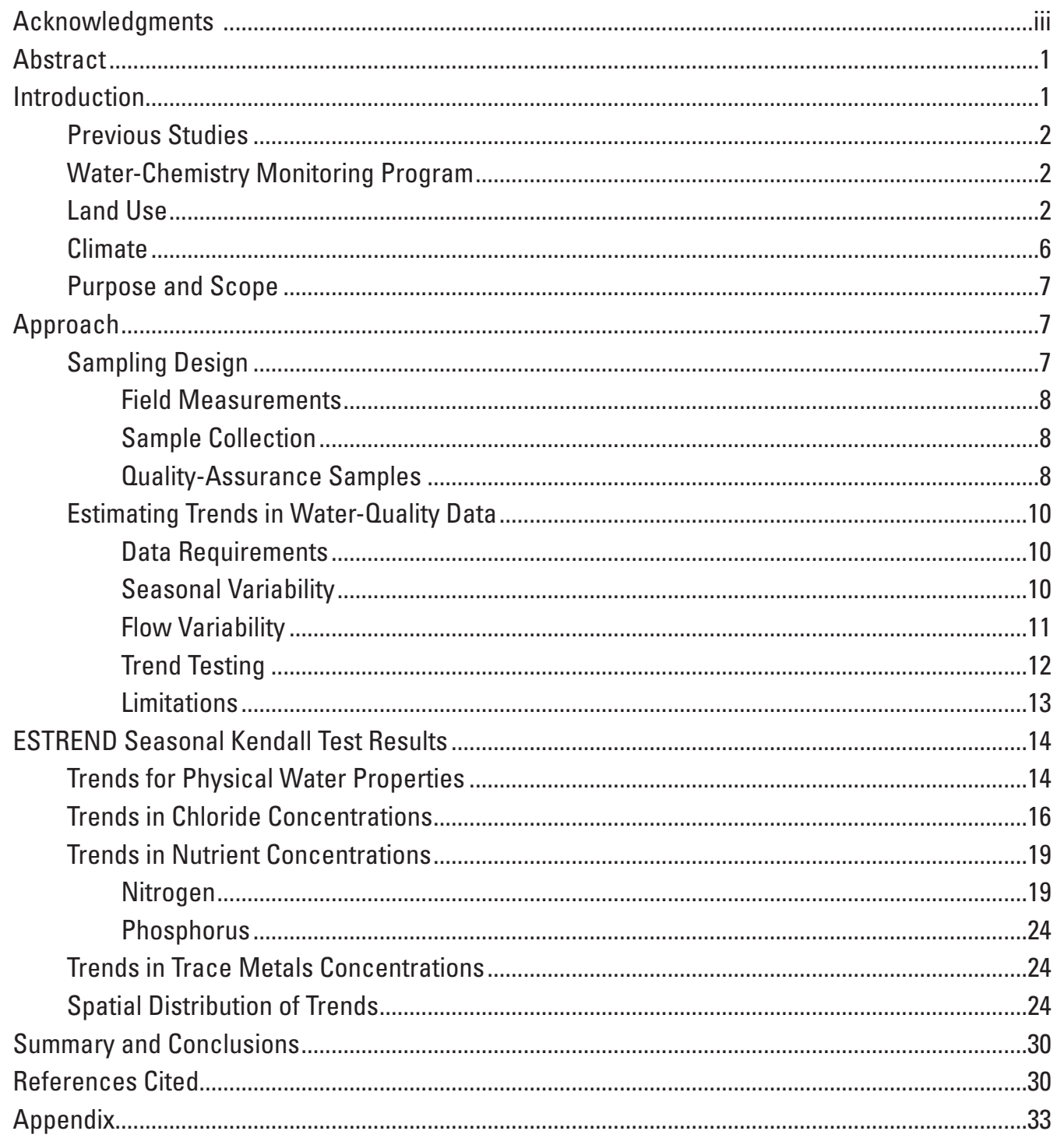

\section{Figures}

1-3. Maps showing:

1. Michigan watersheds studied as part of the Michigan Water-Chemistry

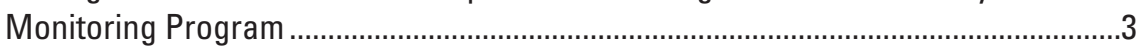

2. Distribution of land cover by major land-use category in Michigan .......................5

3. Climate regions and spatial distribution of 30 -year average annual precipitation in Michigan 
4-8. Graphs showing:

4. Distribution of precipitation by year and region in Michigan, 1998-2005 .7

5. Seasonal variability in nitrate concentration at the Grand River near Eastmanville, Michigan

6. Normal and flow-adjusted concentrations for chloride from 2001 through 2005, Kalamazoo River at New Richmond, Michigan

7. Chloride concentrations over time for selected intensively monitored stream sites in Michigan, 1999 through 2005

8. The relation between chloride concentration and streamflow at selected stream sites in Michigan, 1999 through 2005.

9. Schematic representation of the nitrogen cycle

10-14. Graphs showing:

10. Concentration of Total Kjeldahl nitrogen and streamflow, 2000 through 2005, Clinton River, Michigan....

12. The relations between concentrations of total Kjeldahl nitrogen and nitrate and total suspended solids for the Clinton River, Michigan

11. Concentration of nitrate and streamflow, 2000 through 2005, Clinton River, Michigan

13. The relation between total suspended solids and streamflow for the Clinton River, Michigan .

14. Relation between concentration of phosphorus and total suspended solids in selected Michigan streams

15-18. Maps showing:

15. Trend results for dissolved oxygen, $\mathrm{pH}$, water temperature, and specific conductance by Michigan watershed

16. Trend results for turbidity, total suspended solids, chloride, and phosphorus by Michigan watershed

17. Trend results for ammonia, nitrate, total Kjeldahl nitrogen, and nitrite by Michigan watershed.

18. Trend results for chromium, copper, lead, and mercury by Michigan watershed.

\section{Tables}

1. Sites sampled as part of the Michigan Water Chemistry Monitoring Program .................4

2. Temporal sampling distribution for each site, 1998-2005, Michigan .................................9

3. Summary of environmental and replicate sample results ..............................................10

4. Definition of seasons used for uncensored Seasonal Kendall test ................................12

5. Summary of trend-analysis results for Michigan study sites, 1999-2005 ........................14

6. Trends for various physical properties analyzed at Michigan stream sites,



7. Trend results for chloride at Michigan stream sites, 1999-2005 ...................................17

8. Water-quality criteria for total phosphorus and total nitrogen for U.S. Environmental Protection Agency ecoregions in Michigan ......................................19

9. Trend results for nutrients at Michigan stream sites, 1999-2005 ..................................20

10. Trend results for trace metals at selected Michigan stream sites, 1999-2005 ................25 


\section{Conversion Factors}

\section{Inch/Pound to SI}

\begin{tabular}{|c|c|c|}
\hline Multiply & By & To obtain \\
\hline \multicolumn{3}{|c|}{ Length } \\
\hline inch (in.) & 2.54 & centimeter $(\mathrm{cm})$ \\
\hline inch (in.) & 25.4 & millimeter $(\mathrm{mm})$ \\
\hline foot $(\mathrm{ft})$ & 0.3048 & meter $(\mathrm{m})$ \\
\hline mile (mi) & 1.609 & kilometer $(\mathrm{km})$ \\
\hline
\end{tabular}

Concentrations of chemical constituents in water are given either in milligrams per liter (mg/L), micrograms per liter $(\mu \mathrm{g} / \mathrm{L})$, or nanograms per liter $(\mathrm{ng} / \mathrm{L})$. The unit milliliter $(\mathrm{mL})$ is defined as $1 / 1000$ of a liter. 



\title{
Analysis of Water-Quality Trends for Selected Streams in the Water-Chemistry Monitoring Program, Michigan, 1998-2005
}

\author{
By C. J. Hoard, Lori M. Fuller, and Lisa R. Fogarty
}

\begin{abstract}
In 1998, the Michigan Department of Environmental Quality and the U.S. Geological Survey began a long-term monitoring program to evaluate the water quality of most watersheds in Michigan. Major goals of this Water-Chemistry Monitoring Program were to identify streams exceeding or not meeting State or Federal water-quality standards and to assess if constituent concentrations reflecting water quality in these streams were increasing or decreasing over time. As part of this program, water-quality data collected from 1998 to 2005 were analyzed to identify potential trends. Sixteen water-quality constituents were analyzed at 31 sites across Michigan, 28 of which had sufficient data to analyze for trends. Trend analysis on the various water-quality data was done using the uncensored Seasonal Kendall test within the computer program ESTREND. The most prevalent trend detected throughout the state was for chloride. Chloride trends were detected at 8 of the 28 sites; trends at 7 sites were increasing and the trend at 1 site was decreasing. Although no trends were detected for various nitrogen species or phosphorus, these constituents were detected at levels greater than the U.S. Environmental Protection Agency recommendations for nutrients in water. The results of the trend analysis will help to establish a baseline to evaluate future changes in water quality in Michigan streams.
\end{abstract}

\section{Introduction}

With waters draining to four of the five Great Lakes, Michigan serves as a major source of water to the Great Lakes Basin. Michigan has 36,350 mi of rivers and streams that drain 62 major watersheds. Michigan relies on the surface water of the state for drinking, recreation, and supporting wildlife. The quality of these waters is essential for the health and economy of Michigan.

In 1998, citizens of Michigan passed the Clean Michigan Initiative (CMI) to clean up, protect, and enhance the environmental infrastructure of Michigan. In 1998, because of expanding water-quality data needs, resulting in part from the new CMI program, the MDEQ and USGS jointly designed and implemented the Water-Chemistry Monitoring Program (WCMP) for long-term monitoring of streams in Michigan (Michigan Department of Environmental Quality, 2001). Major goals of the WCMP were to identify streams that do not meet water-quality standards and to assess if constituents reflecting water quality in these streams were increasing or decreasing in concentration over time.

Long-term water-quality monitoring is necessary to detect changes or trends in rivers and streams in Michigan. Changes in land management, water-treatment practices, and land use commonly lead to changes in chemical inputs to nearby surface waters. The WCMP long-term water-quality monitoring used a two-phased approach. Initially, the WCMP helped to establish baseline water quality for rivers and streams. Once the baseline water quality was established, continued monitoring allowed assessment of water-quality trends. This type of monitoring program can help identify the need for remediation or changes in current management practices and also verify that changes to prior water or landmanagement practices have had an effect on water quality.

Changes in water quality of a river or stream can be the result of several factors. For example, shifting from agricultural to residential land use could result in changes in water quality. As the population grows, so does the number and size of urban centers. In several areas of Michigan, agricultural lands are being converted to residential or commercial land use to meet the needs of the growing population. As the population continues to grow, water-management practices need to be adjusted to handle the increased demand on water resources as well as to treat the increased amount of wastewater generated. Through an understanding of the hydrologic processes governing our environment, there is recognition that land-management practices can be improved in an effort to control the amount and type of chemical inputs into our surface waters. For example, the growing demand for alternative fuels may lead to increased crop production and the increased use of associated agricultural chemicals. Land-management practices, such as agricultural best-management practices (BMPs), can be instituted and improved to control the amount 
of and types of chemicals entering the environment from increased crop production. Alternatively, changes in land use with no adaptation of water or land-management practices may lead to degradation of water quality in surface water.

For most streams currently sampled as part of the WCMP program, at least 5 years of water-quality data were available. Statistical techniques used to estimate trends have a minimum period of record necessary for analysis. The technique used in this study required a minimum of 5 years of continuous data.

\section{Previous Studies}

Blumer (1993) published results for stream water-quality analyses for 10 monitoring stations throughout Michigan from 1987 to 1989 and trend analyses for 16 monitoring stations from 1975 to 1989. Syed and Fogarty (2005) published results of water-quality trend analyses for nine streams in Michigan sampled from 1978 to 1995 as part of the USGS National Stream Quality Accounting Network (NASQAN). Results from these studies showed both upward and downward trends in concentrations of several water-quality constituents during the study periods. From 1978 to 1995, several changes, which were brought about by the passage of the Clean Water Act of 1972, helped protect water quality. Because of changes in policy, land use, and climate over time, changes in waterquality trends for various constituents were expected (Syed and Fogarty, 2005).

In 1998, the MDEQ, in cooperation with the USGS Michigan Water Science Center, began monitoring 31 stream sites in Michigan as part of a long-term monitoring program. This program included monitoring the water chemistry of 27 watersheds draining to the Great Lakes, some of which were also part of the historical NASQAN program (Michigan Department of Environmental Quality, 2008b).

\section{Water-Chemistry Monitoring Program}

In 1998, the MDEQ began monitoring 27 different watersheds in Michigan as part of the WCMP (fig. 1). The WCMP incorporated the watershed-management units and 5-year rotational cycle used by the MDEQ Ambient Surface Water Chemistry Monitoring Program (Michigan Department of Environmental Quality, 2001) to assess Michigan streams, Great Lakes connecting channels, and bays. This was done to ensure that specific watersheds were monitored in a 5-year cycle to assist in (1) statewide water-quality assessments, (2) the National Pollutant Discharge Elimination System (NPDES) permitting process, and (3) resource-management decisions.

The areas selected for monitoring coincide with USGS eight-digit hydrologic units throughout the state. Sampling locations in these hydrologic units were selected near the mouth of major streams draining to the Great Lakes. This was done to provide a sample that best represents the average water quality of the hydrologic unit. Land use varied from undeveloped forest in the northern parts of the state to highly developed urban centers in the southern part of the state (fig. 2). Six hydrologic units representing the varying conditions from urban to undeveloped were monitored intensively every year. Twenty-one other hydrologic units were monitored through 25 additional sampling sites, also representing a broad range of land-use conditions (table 1).

\section{Land Use}

Land use is a major factor affecting streamflow and the types of constituents that may run off to streams. For instance, in a watershed with a large amount of agricultural land use, there is a potential for increased input of nutrients to the stream as a result of fertilizer usage. Other land-use categories may have unique effects on water quality based on the possible types of chemicals available to run off into the streams.

Four major categories were used in this study to classify the land use throughout the State of Michigan. The major categories used were agricultural, urban, undeveloped, and water. Agricultural land use includes land used for the production of cultivated crops, livestock, and orchards. The urban land-use category includes commercial, industrial, and residential areas. The undeveloped land-use category is used to classify many categories but primarily forests, shrublands, and wetlands. The water land-use category is area covered by large bodies of water like lakes or large rivers. Much of the land use identified in watersheds in the Upper Peninsula and northern Lower Peninsula of Michigan is comprised of forest, wetland, and other open or undeveloped land coverage. In contrast, the southern Lower Peninsula of Michigan is primarily agricultural and urban (fig. 2). 


\section{EXPLANATION}



1 Watershed number

Sampling location
Integrator
Intensive
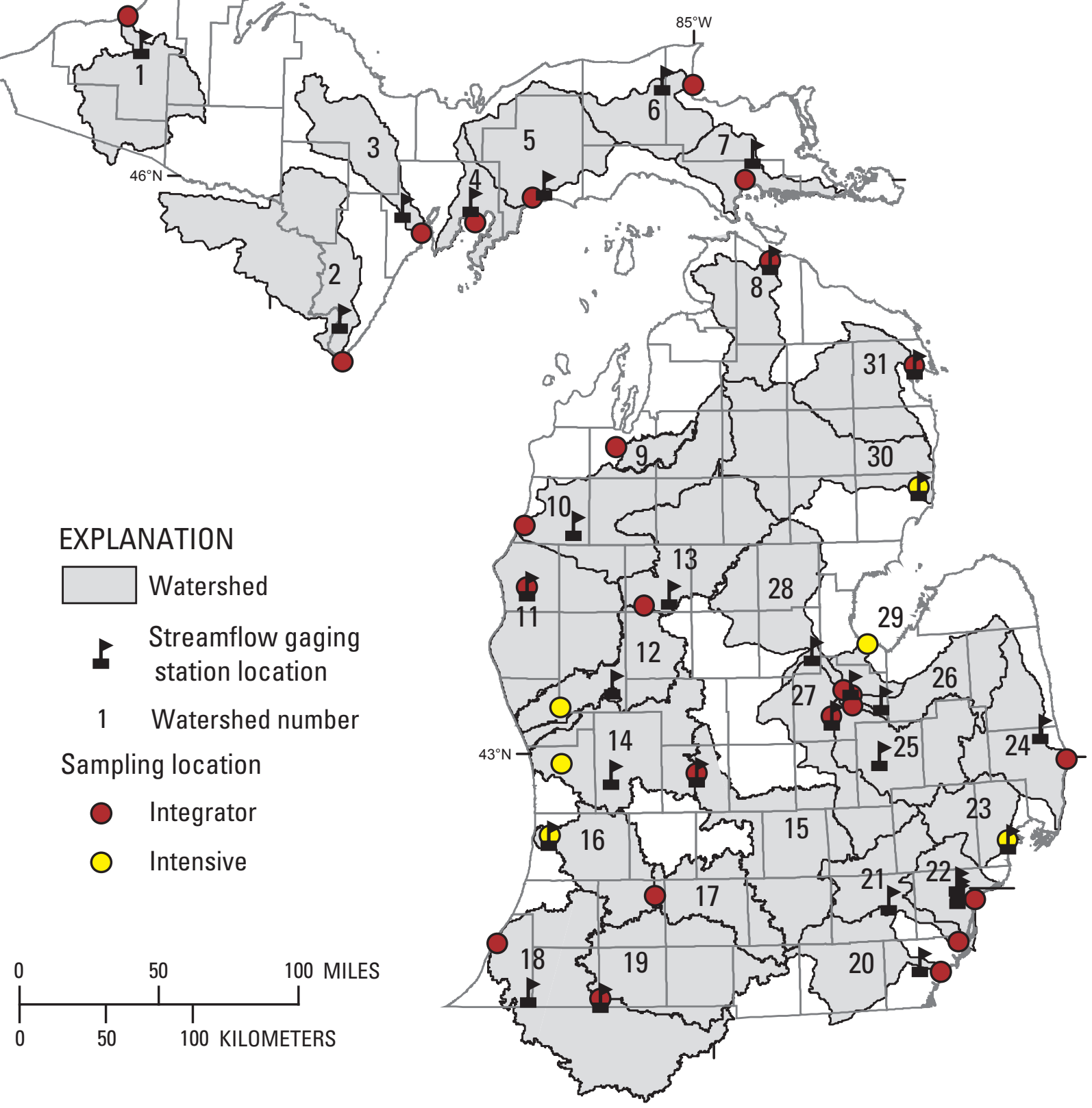

Basemap: State and County boundaries from the Michigan Geographic Framework, 2003. Watershed boundaries from 1:250,000 Hydrologic Unit Codes (U.S. Geological Survey, 1994)and split if necessary using upstream 1:24,000 watershed boundaries (Michigan Department of Environmental Quality, 1998).

Figure 1. Michigan watersheds studied as part of the Michigan Water-Chemistry Monitoring Program. 
Table 1. Sites sampled as part of the Michigan Water Chemistry Monitoring Program.

[Bold type indicates intensively sampled site; USGS, U.S. Geological Survey; USEPA, U.S. Environmental Protection Agency]

\begin{tabular}{|c|c|c|c|c|c|}
\hline $\begin{array}{c}\text { Watershed } \\
\text { number }\end{array}$ & Site name & USGS station number & $\begin{array}{c}\text { USEPA STORET } \\
\text { number }\end{array}$ & Latitude & Longitude \\
\hline 1 & Ontonagon River at Ontonagon, Mich. & 04040018 & 660038 & 46.86744 & -89.31709 \\
\hline 2 & Menominee River at Menominee, Mich. & 04067648 & 550038 & 45.10637 & -87.63566 \\
\hline 3 & Escanaba River at Wells, Mich. & 040590345 & 210102 & 45.78111 & -87.06750 \\
\hline 4 & Sturgeon River at County Road 499 at Nahma, Mich. & 04057521 & 210032 & 45.84081 & -86.66875 \\
\hline 5 & Manistique River Above Manistique, Mich. & 04057004 & 770073 & 45.97164 & -86.24320 \\
\hline 6 & Tahquamenon River at Emerson, Mich. & 04045510 & 170141 & 46.55641 & -85.03870 \\
\hline 7 & Pine River near Charles, Mich. & 04127925 & 490006 & 46.05696 & -84.65699 \\
\hline 8 & Cheboygan River at Cheboygan, Mich. & 04132052 & 160073 & 45.63390 & -84.48115 \\
\hline 9 & Boardman River near Traverse City, Mich. & 04127200 & 280014 & 44.67528 & -85.63091 \\
\hline 10 & Manistee River at Parkdale, Mich. & 04126010 & 510088 & 44.26417 & -86.29536 \\
\hline 11 & Pere Marquette River at Scottville, Mich. & 04122500 & 530027 & 43.94501 & -86.27869 \\
\hline 12 & (lower) Muskegon River near Bridgeton, Mich. & 04122030 & 610273 & 43.31807 & -86.03644 \\
\hline 13 & (upper) Muskegon River near Hersey, Mich. & 04121621 & 670008 & 43.84722 & -85.43222 \\
\hline 14 & (lower) Grand River near Eastmanville, Mich. & 04119400 & 700123 & 43.02419 & -86.02644 \\
\hline 15 & (upper) Grand River at Ionia, Mich. & 04116000 & 340025 & 42.97198 & -85.06917 \\
\hline 16 & (lower) Kalamazoo River at New Richmond, Mich. & 04108660 & 030077 & 42.65169 & -86.10781 \\
\hline 17 & (upper) Kalamazoo River near Augusta, Mich. & 04105707 & 390057 & 42.32560 & -85.35889 \\
\hline 18 & (lower) St. Joseph River at Napier Ave at St. Joseph, Mich. & 04102080 & 110628 & 42.08921 & -86.47474 \\
\hline 19 & (upper) St. Joseph River at Mottville, Mich. & 04099000 & 750273 & 41.80088 & -85.75610 \\
\hline 20 & River Raisin at Monroe, Mich. & 04176540 & 580046 & 41.91338 & -83.38465 \\
\hline 21 & Huron River at Rockwood, Mich. & 04175120 & 580364 & 42.06417 & -83.25389 \\
\hline 22 & River Rouge at River Rouge, Mich. & 04168550 & 820070 & 42.28059 & -83.12881 \\
\hline 23 & Clinton River at Gratiot Avenue at Mt. Clemens, Mich. & 04165553 & 500233 & 42.58392 & $\mathbf{- 8 2 . 8 8 2 7 0}$ \\
\hline 24 & Black River at Port Huron, Mich. & 04160075 & 740385 & 42.99440 & -82.44500 \\
\hline 25 & Flint River near Fosters, Mich. & 04149000 & 730285 & 43.30836 & -83.95358 \\
\hline 26 & Cass River near Bridgeport, Mich. & 04152002 & 730024 & 43.36503 & -83.95497 \\
\hline 27 & Shiawassee River near Fergus, Mich. & 04145000 & 730023 & 43.25475 & -84.10553 \\
\hline 28 & Tittabawassee River at Center Road near Saginaw, Mich. & 04156510 & 730025 & 43.39364 & -84.01498 \\
\hline 29 & Saginaw River at Weadock Road at Essexville, Mich. & 04157065 & 090177 & 43.62808 & $\mathbf{- 8 3 . 8 3 6 6 4}$ \\
\hline 30 & Au Sable River near Au Sable, Mich. & 04137500 & 350061 & 44.43640 & $-\mathbf{8 3 . 4 3 3 8 6}$ \\
\hline 31 & Thunder Bay at Alpena, Mich. & 04135020 & 040123 & 45.07085 & -83.43775 \\
\hline
\end{tabular}



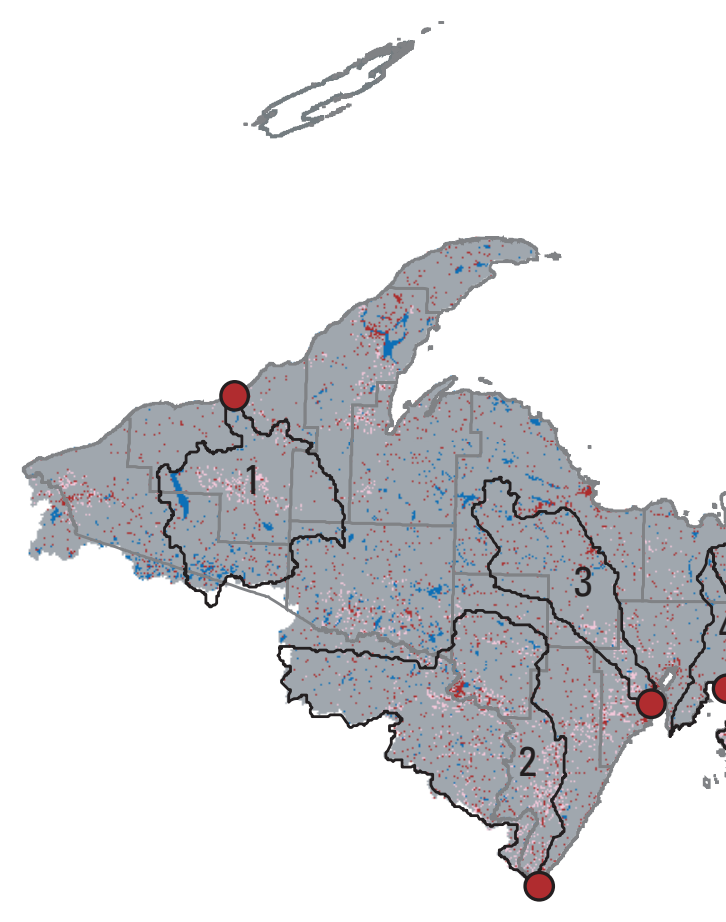

\section{EXPLANATION}

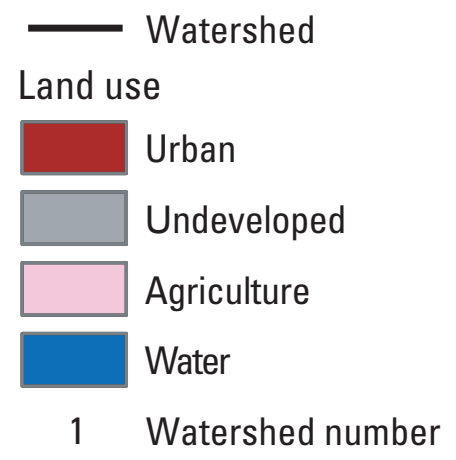

Sampling location

Integrator

Intensive
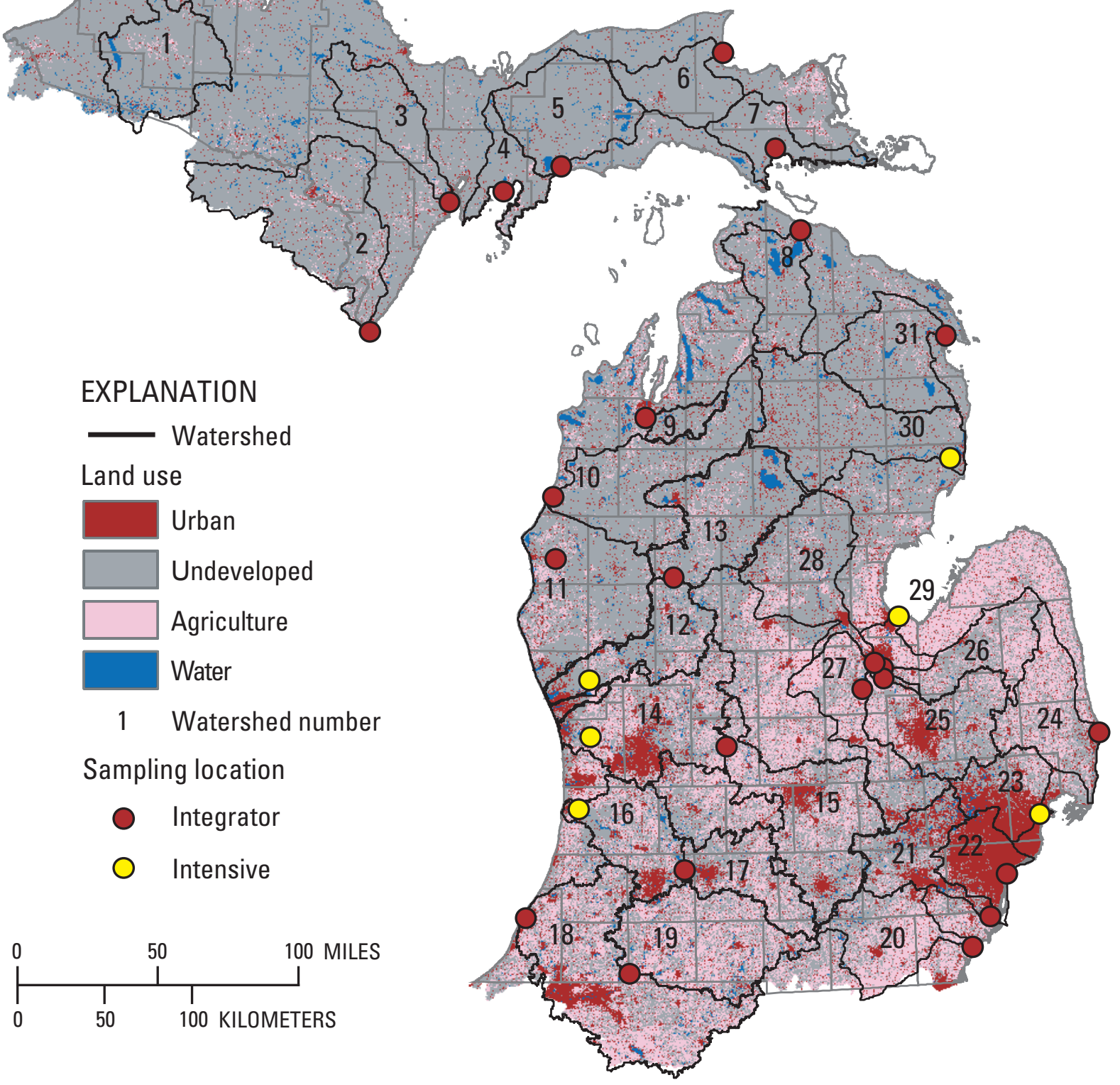

Basemap: State and County boundaries from the Michigan Geographic Framework, 2003.Watershed boundaries from 1:250,000 Hydrologic Unit Codes (U.S. Geological Survey, 1994) and split if necessary using upstream 1:24,000 watershed boundaries (Michigan Department of Environmental Quality, 1998).

Figure 2. Distribution of land cover by major land-use category in Michigan. 


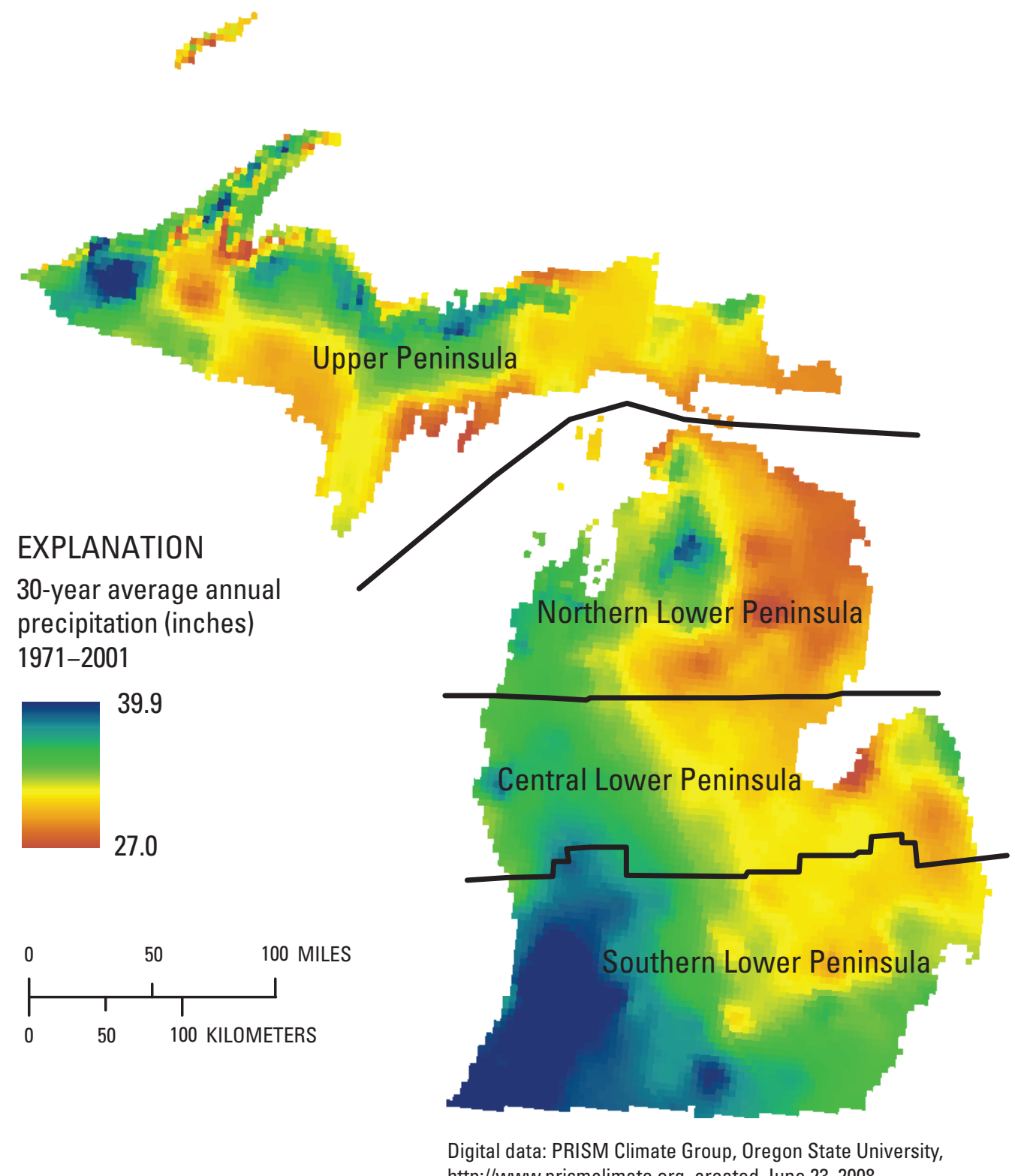

http://www.prismclimate.org, created June 23, 2008

Figure 3. Climate regions and spatial distribution of 30-year average annual precipitation in Michigan.

\section{Climate}

Climate differences can be expected between the different regions of the state. In particular, the distribution of precipitation across Michigan is highly variable (fig. 3). Precipitation is a major factor affecting streamflow. Precipitation can contribute to streamflow either as direct runoff from the land surface to streams or as water that has infiltrated into groundwater and is discharged to streams through base flow. In addition, higher precipitation may lead to a higher contribution of chemical inputs to streams because runoff from the land surface frequently carries constituents applied to or deposited on the land surface.
The National Oceanic and Atmospheric Administration (NOAA) defined 10 climate divisions for the State of Michigan. For simplicity, these divisions were grouped into four regions: the Upper Peninsula, Northern Lower Peninsula, Central Lower Peninsula, and Southern Lower Peninsula (fig. 3). Average annual precipitation, by region, from 1998 to 2005 (National Oceanic and Atmospheric Administration, 1999-2006), ranged from 27 in. (for the Upper Peninsula region in 2000) to 41 in. (for the Southern Lower Peninsula region in 2000). The areas of relatively high precipitation were near the Great Lakes coastlines, which show the distinct influence of lake-effect precipitation. Average annual precipitation for each region for the study period is shown in figure 4 . 


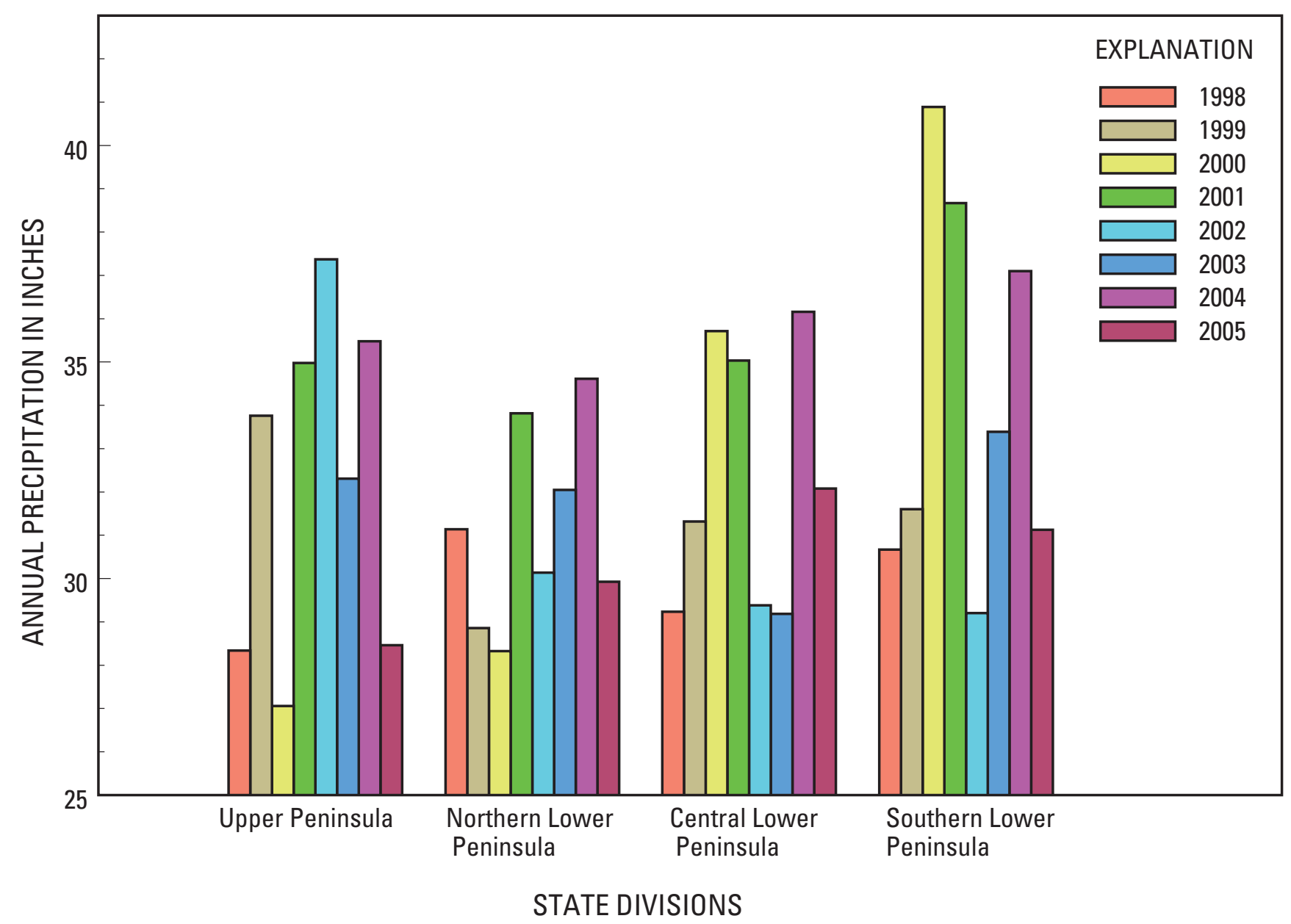

Figure 4. Distribution of precipitation by year and region in Michigan, 1998-2005 (National Oceanic and Atmospheric Administration, 1999-2006).

\section{Purpose and Scope}

This report summarizes estimated trends in water-quality data collected as part of the MDEQ WCMP program from 1998 to 2005 . The report describes the seasonal trend-analysis procedure used to evaluate trends in select water-quality constituents for 31 stream sites across 27 watersheds in Michigan. The data collected and analyzed in this report lay the foundation for future analysis of trends as part of the WCMP long-term water-quality monitoring effort. As additional data are collected, the trend analysis can be updated to reflect the most current conditions. Because this report is intended to serve as a preliminary analysis of the long-term state monitoring program, long-term predictions of water quality have not been included. Potential factors that may have influenced past water quality at these sites are mentioned, but the intent of this report is not to determine sources of contamination or remedial action strategies.

\section{Approach}

\section{Sampling Design}

In cooperation with MDEQ, the USGS collected waterquality samples at 6 intensively monitored sites (Au Sable River, Clinton River, Grand River, Kalamazoo River, Muskegon River, and Saginaw River) 12 times a year from 2001 to present (2008). Additional samples also were collected from 1998 to 2000; however, the data collected in that time span were not continuous. This report summarizes the trends for water-quality data collected from 1998 to 2005 . The sampling design for the WCMP study was to collect 8 of the 12 samples during high-flow conditions. The remaining four samples were collected during low-flow conditions. Typically, samples were collected March through November, but on a few occasions samples were collected in January and February during major thaw and runoff events. 
In addition to the 6 intensively monitored sites sampled each year from 2001 to present (2008), 25 integrator sites also were sampled 12 times per year, but on a 5 -year rotating basis. During non-intensive years, these integrator sites were sampled quarterly, independent of streamflow conditions. For example, the Cass River (table 2) was sampled 12 times in 2001 and 4 times per year over the next 4 years. Again, samples also were collected during 1998-2000 for the integrator sites, but the water-quality record in that time span was not continuous. The number of samples collected each year for the WCMP monitoring program is summarized in table 2.

\section{Field Measurements}

Field measurements are the measurements of physical and chemical properties of water at a sample site as close as possible in time and space to the stream-water-quality sample being collected (Wilde and Radtke, 2005). Certain constituents like temperature, $\mathrm{pH}$, dissolved oxygen (DO), and specific conductance are best measured in the field because of the inability to maintain those constituents during the shipping and analysis process. To measure these onsite constituents, a calibrated multiparameter water-quality instrument was used at each sampling location. Where appropriate, three measurements were taken: one at a distance of one-quarter of the stream width from the right bank, one in the center of the channel, and one at a distance of one-quarter of the stream width from the left bank. These three measurements were then averaged and used to represent the conditions of the stream. When three sections were not possible, the measurements were taken from the center of the channel at the sampling site. All measurements were taken at approximately $2 \mathrm{ft}$ below the water surface.

Mean daily streamflow values for each sample were obtained from the streamflow gaging station at the sampling site. When a streamflow-gaging station was not located at the sampling site, a drainage-area multiplier was determined for the area that contributed flow to that sample site. This multiplier was used in conjunction with the flow from a nearby streamflow-gaging station, usually located upstream, to estimate the mean daily streamflow at the sample location. If more than one streamflow-gaging station was near a sampling location, a drainage-area multiplier was developed and used in conjunction with streamflow values from multiple streamflowgaging stations to estimate the mean daily streamflow for the sampling location.

\section{Sample Collection}

For streams that could be safely waded, water samples for trace metals, total mercury, nutrients, chloride, and total suspended solids (TSS) were collected as a single grab sample in the center of flow about 2-3 ft below the water surface. For streams that could not be waded, water samples for mercury and trace metals were collected using a peristaltic pump either from a bridge or from a boat with C-Flex ${ }^{\circledR}$ tubing connected to $6-15 \mathrm{ft}$ of Teflon ${ }^{\circledR}$ tubing. Teflon tubing was connected to a Teflon counter weight and dropped below the surface, approximately 2-3 ft, in the center of the channel. Water samples for mercury analysis were collected in $500 \mathrm{~mL}$ Teflon bottles, and water samples for analysis of trace metals were collected in $250 \mathrm{~mL}$ Teflon bottles. Prior to sample collection, the tubing was rinsed with sample water for 5 minutes. Sample bottles were sealed in plastic bags and placed on ice in a cooler until final processing and transportation. The Teflon and C-Flex ${ }^{\circledR}$ tubing were rinsed with 2-percent nitric acid and then rinsed in deionized water. The Teflon line was stored until the next sampling, whereas the C-Flex ${ }^{\circledR}$ tubing was sent back to the Wisconsin State Lab of Hygiene (WSLH). Water samples for mercury and trace metals were shipped in a cooler with ice to the WSLH, Madison, Wis., within 48 hours of sample collection.

Water samples for nutrients, chloride, and TSS were collected in $500 \mathrm{~mL}$ polypropylene bottles using grab, peristaltic pump, sampling can, and (or) Van Dorn samplers, as appropriate. Sample bottles were placed on ice in a cooler until final processing and transportation. To improve sample preservation, the samples that were analyzed for total organic carbon, nitrate, nitrite, ammonia, Total Kjeldahl nitrogen (TKN), and total phosphorus (TP) were amended with 10 drops of concentrated sulfuric acid in the field. Samples were placed in a cooler with ice and shipped or transported to the MDEQ Environmental Laboratory, Lansing, Mich., within 48 hours of sample collection. Sample analyses and results are summarized in MDEQ water-chemistry trend monitoring reports (Michigan Department of Environmental Quality, 2001; Michigan Department of Environmental Quality, 2002: Michigan Department of Environmental Quality, 2003; Michigan Department of Environmental Quality, 2004; Michigan Department of Environmental Quality, 2005; Michigan Department of Environmental Quality, 2006a; Michigan Department of Environmental Quality, 2008a).

\section{Quality-Assurance Samples}

As part of the WCMP, quality-assurance samples that consisted of a series of blank and replicate samples were collected. Blank samples were used to assess whether or not the sampling techniques or methods were introducing contamination to the samples collected. Between 6 and 15 blank samples were collected and analyzed for all the constituents each year. Results from the field blanks and trip blanks were below quantification levels for all the constituents reported in the study with the exception of specific trace metal samples. For the 72 blank samples analyzed for trace metals, concentrations of chromium and mercury were greater than their specified detection levels 19 and 4 percent of the time, respectively. This indicates that during some step in the sample collection/ analysis process, some low-level contamination of the sample may have occurred with regard to certain trace metals. 
Table 2. Temporal sampling distribution for each site, 1998-2005, Michigan.

\begin{tabular}{|c|c|c|c|c|c|c|c|c|c|c|}
\hline \multirow{2}{*}{$\begin{array}{l}\text { Watershed } \\
\text { number }\end{array}$} & \multirow{2}{*}{ Site name } & \multicolumn{8}{|c|}{ Samples by year } & \multirow{2}{*}{$\begin{array}{c}\text { Total } \\
\text { samples }\end{array}$} \\
\hline & & 1998 & 1999 & 2000 & 2001 & 2002 & 2003 & 2004 & 2005 & \\
\hline \multicolumn{11}{|c|}{ Intensive sites } \\
\hline 12 & Muskegon River near Bridgeton & 0 & 12 & 6 & 12 & 12 & 12 & 12 & 12 & 78 \\
\hline 14 & Grand River near Eastmanville & 0 & 13 & 6 & 12 & 12 & 12 & 12 & 12 & 79 \\
\hline 16 & Kalamazoo River at New Richmond & 0 & 13 & 6 & 12 & 12 & 12 & 12 & 12 & 79 \\
\hline 23 & Clinton River at Gratiot Avenue at Mt. Clemens & 13 & 0 & 6 & 12 & 12 & 12 & 12 & 12 & 79 \\
\hline 29 & Saginaw River at Weadock Road at Essexville & 8 & 0 & 0 & 12 & 12 & 12 & 12 & 12 & 68 \\
\hline 30 & Au Sable River near Au Sable & 11 & 0 & 6 & 12 & 12 & 12 & 12 & 12 & 77 \\
\hline \multicolumn{11}{|c|}{ Integrator sites } \\
\hline 1 & Ontonagon River at Ontonagon & 0 & 0 & 3 & 4 & 4 & 4 & 4 & 4 & 23 \\
\hline 2 & Menominee River at Menominee & 0 & 0 & 3 & 4 & 12 & 4 & 4 & 4 & 31 \\
\hline 3 & Escanaba River at Wells & 0 & 13 & 6 & 4 & 4 & 4 & 4 & 12 & 47 \\
\hline 4 & Sturgeon River at County Road 499 at Nahma & 0 & 0 & 3 & 12 & 4 & 4 & 4 & 4 & 31 \\
\hline 5 & Manistique River Above Manistique & 0 & 13 & 3 & 4 & 4 & 4 & 12 & 4 & 44 \\
\hline 6 & Tahquamenon River at Emerson & 0 & 13 & 3 & 4 & 4 & 4 & 12 & 4 & 44 \\
\hline 7 & Pine River near Charles & 0 & 0 & 3 & 4 & 4 & 4 & 12 & 4 & 31 \\
\hline 8 & Cheboygan River at Cheboygan & 0 & 0 & 6 & 4 & 4 & 4 & 4 & 12 & 34 \\
\hline 9 & Boardman River near Traverse City & 0 & 0 & 0 & 4 & 4 & 12 & 4 & 4 & 28 \\
\hline 10 & Manistee River at Parkdale & 0 & 0 & 3 & 4 & 4 & 4 & 12 & 4 & 31 \\
\hline 11 & Pere Marquette River at Scottville & 0 & 12 & 6 & 4 & 5 & 4 & 4 & 12 & 47 \\
\hline 13 & Muskegon River near Hersey & 0 & 0 & 3 & 12 & 5 & 4 & 4 & 4 & 32 \\
\hline 15 & Grand River at Ionia & 0 & 0 & 3 & 12 & 4 & 4 & 4 & 4 & 31 \\
\hline 17 & Kalamazoo River near Augusta & 0 & 0 & 3 & 4 & 4 & 4 & 12 & 4 & 31 \\
\hline 18 & St. Joseph River at Napier Ave at St. Joseph & 0 & 12 & 3 & 12 & 4 & 4 & 4 & 12 & 51 \\
\hline 19 & St. Joseph River at Mottville & 0 & 0 & 6 & 4 & 4 & 4 & 4 & 4 & 26 \\
\hline 20 & River Raisin at Monroe & 12 & 0 & 3 & 4 & 4 & 12 & 4 & 4 & 43 \\
\hline 21 & Huron River at Rockwood & 12 & 0 & 3 & 4 & 12 & 4 & 4 & 4 & 43 \\
\hline 22 & River Rouge at River Rouge & 13 & 0 & 6 & 4 & 4 & 4 & 4 & 12 & 47 \\
\hline 24 & Black River at Port Huron & 0 & 0 & 3 & 4 & 4 & 4 & 4 & 4 & 23 \\
\hline 25 & Flint River near Fosters & 0 & 0 & 3 & 4 & 4 & 12 & 4 & 4 & 31 \\
\hline 26 & Cass River near Bridgeport & 0 & 0 & 3 & 12 & 4 & 4 & 4 & 4 & 31 \\
\hline 27 & Shiawassee River near Fergus & 13 & 0 & 6 & 4 & 4 & 4 & 4 & 12 & 47 \\
\hline 28 & Tittabawassee River at Center Road near Saginaw & 13 & 0 & 3 & 4 & 12 & 4 & 4 & 4 & 44 \\
\hline 31 & Thunder Bay at Alpena & 11 & 0 & 6 & 4 & 4 & 4 & 4 & 12 & 45 \\
\hline
\end{tabular}


Replicate samples were used to assist in determining the variability in constituent concentrations as a result of sample collection, processing, and lab analysis. The number of replicate samples collected ranged from 68 to 124 . Comparison of the environmental samples to the replicate samples collected (table 3) reveals that most constituents have a low percent relative standard deviation. This indicates there is good precision in the collection and analysis of the constituents sampled. However, total suspended solids had a higher percent relative standard deviation than the other constituents sampled. This indicates there is lower precision with the collection and analysis of total suspended sediment.

\section{Estimating Trends in Water-Quality Data}

To evaluate potential trends in select water-quality constituents, the statistical software package S-Plus was used in conjunction with the trend-estimating program ESTREND (Schertz and others, 1991). ESTREND allows for the use of both parametric as well as nonparametric techniques to test for potential trends. The nonparametric approach of the uncensored Seasonal Kendall test was chosen for this study because of the characteristics of the water-quality data collected in the WCMP program. The water-quality data collected as part of this program generally 1 ) were not normally distributed; 2) have seasonal variability in concentrations; 3 ) have variability in concentrations related to streamflow; 4) have some outlier concentration values; 5 ) have some censored concentration values; and 6) have some missing concentration values. The uncensored Seasonal Kendall test was able to account for these characteristics of the data, whereas standard parametric procedures would have difficulty evaluating this data set (Hirsch and others, 1982; Hirsch and others, 1991).

\section{Data Requirements}

The uncensored Seasonal Kendall test for trend detection has four primary data requirements. The period of record for a water-quality site must be at least 5 years (Schertz and others, 1991). The minimum number of samples that can be tested for at a particular sampling site is at least 3 times the number of designated annual seasons, or at least a minimum of 10 samples (Schertz and others, 1991). Additionally, a minimum percentage, in this case 30 percent, of the total possible number of seasonal water-quality values in the beginning and ending fifths of the record must be present (Schertz and others, 1991). Finally, no more than 5 percent of the observed values can be censored (Schertz and others, 1991). Censored values are results for concentrations of constituents that are less than the laboratory method reporting level. These values are not quantified but are given a value of less than some reporting level. Three sites (watershed numbers 9, 29, and 31, fig. 1) were not evaluated for trends because the site did not have the minimum length of record, had too few observations, or had too many censored values. In the case of the Saginaw River site (watershed number 29), even though it was intensively sampled, the site was not be sampled between November 1998 and July 2001. This gap in the record was too large for the trend-analysis program ESTREND to provide a reliable trend estimate.

\section{Seasonal Variability}

Seasonal differences in concentrations of water-quality constituents can complicate the detection of trends. The variability in total nitrate concentrations by month for the Grand River near Eastmanville, Mich., is shown in figure 5. To detect

Table 3. Summary of environmental and replicate sample results.

[mg/L, milligrams per liter; $\mu \mathrm{g} / \mathrm{L}$, micrograms per liter; $\mathrm{ng} / \mathrm{L}$, nanograms per liter; $\mathrm{P}$, phosphorus; $\mathrm{N}, \mathrm{Nitrogen}]$

\begin{tabular}{|c|c|c|c|c|c|c|}
\hline Constituent & $\begin{array}{l}\text { Number of } \\
\text { replicate } \\
\text { samples }\end{array}$ & $\begin{array}{c}\text { Mean } \\
\text { environmental } \\
\text { sample } \\
\text { concentration }\end{array}$ & $\begin{array}{c}\text { Mean replicate } \\
\text { sample } \\
\text { concentration }\end{array}$ & $\begin{array}{l}\text { Mean of the } \\
\text { environemntal/ } \\
\text { replicate pair } \\
\text { concentration }\end{array}$ & $\begin{array}{l}\text { Mean standard } \\
\text { deviation }\end{array}$ & $\begin{array}{c}\text { Mean percent } \\
\text { relative } \\
\text { standard } \\
\text { deviation }\end{array}$ \\
\hline Chloride (mg/L) & 124 & 42.234 & 42.056 & 42.145 & 0.445 & 2.8 \\
\hline Chromium $(\mu \mathrm{g} / \mathrm{L})$ & 84 & 0.482 & 0.488 & 0.485 & 0.029 & 9.1 \\
\hline Mercury (ng/L) & 65 & 2.816 & 2.853 & 2.834 & 0.281 & 11.0 \\
\hline Nitrate $(\mathrm{mg} / \mathrm{L}$ as $\mathrm{N})$ & 86 & 0.982 & 0.979 & 0.980 & 0.035 & 4.3 \\
\hline Nitrite (mg/L as N) & 72 & 0.017 & 0.017 & 0.017 & 0.00038 & 3.0 \\
\hline Total Phosphorus (mg/L as P) & 74 & 0.052 & 0.052 & 0.052 & 0.002 & 5.7 \\
\hline
\end{tabular}




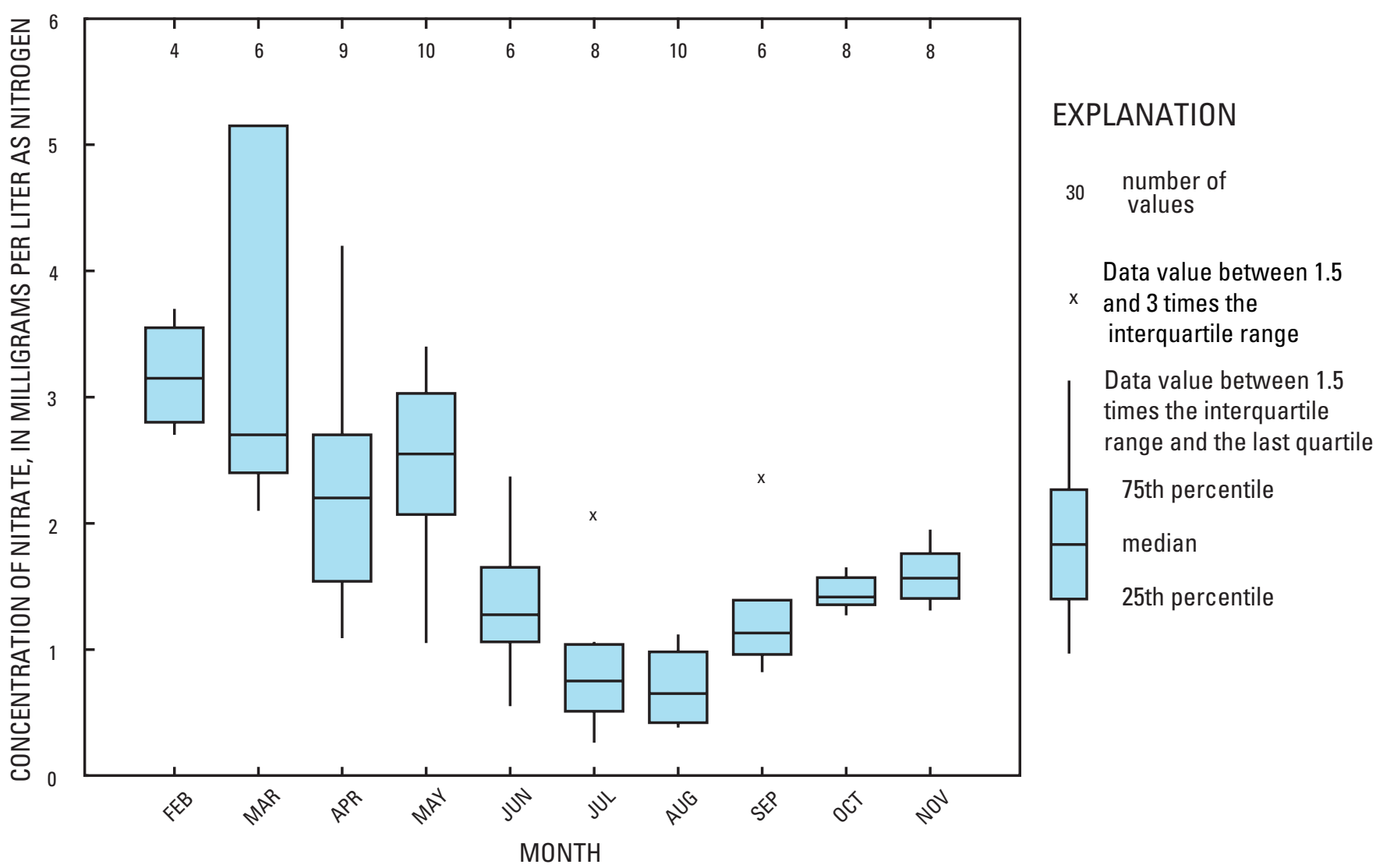

Figure 5. Seasonal variability in nitrate concentration at the Grand River near Eastmanville, Michigan.

a trend, the effect of seasonal differences on a constituent concentration needs to be removed. The ESTREND program does this by dividing a year into seasons and only comparing sample data collected from similar seasons to estimate a trend (Schertz and others, 1991).

Seasons, for the different sites and constituents analyzed for trends, were defined on the basis of the sampling frequency at a site and the distribution of concentration data over time. The number of seasons per year used in this study was 12,6 , 4,3 , or 2 (table 4). The ESTREND program has an automated procedure for selecting the most appropriate number of seasons to use in the uncensored Seasonal Kendall test (Schertz and others, 1991). The program combines the beginning and ending fifths of the water-quality data for a constituent and compares that to the middle three-fifths of the record. This procedure then calculates the total possible number of seasonal comparisons that could be made given a certain period of record and compares that to the actual number of seasonal comparisons that can be made on the basis of the data available for a certain constituent at a site. The seasonal definition that had the largest number of seasons and that had 50 percent or more of the total possible seasonal matches was selected. Emphasis was placed on the beginning and ending fifths of the record, so the seasonal definition procedure weighted those portions of the record higher than the middle three-fifths.
When a season for a particular year had multiple samples, the most central value with respect to time that also was paired with a flow estimate was selected to represent the season (Schertz and others, 1991).

\section{Flow Variability}

The concentrations of various water-quality constituents commonly are related to streamflow. As a result, the variance in a streams flow may be one of the major influences on a constituent concentration over time. In many cases, the influence of streamflow may be greater than the influence of other anthropogenic factors on constituent concentrations. In this case, any trend analysis test used essentially would be examining trends in streamflow as opposed to trends in constituent concentrations. To better understand the anthropogenic effect on the concentrations of water-quality constituents in streams, the effect that variation in streamflow has on constituent concentrations needs to be removed.

ESTREND provides a utility to remove the variability in constituent concentrations as a result of streamflow variability. This utility requires a streamflow estimate for each constituent concentration at each site being tested. ESTREND then computes a relation between the constituent concentration and 
Table 4. Definition of seasons used for uncensored Seasonal Kendall test.

\begin{tabular}{ccccccc}
\hline \multirow{2}{*}{$\begin{array}{c}\text { Number of } \\
\text { seasons } \\
\text { per year }\end{array}$} & $\mathbf{1}$ & $\mathbf{2}$ & $\mathbf{3}$ & $\mathbf{4}$ & $\mathbf{5}$ & $\mathbf{6}$ \\
\cline { 2 - 7 } & $01 / 01-02 / 28$ & $03 / 01-03 / 24$ & $03 / 25-04 / 18$ & $04 / 19-05 / 12$ & $05 / 13-06 / 06$ & $06 / 07-06 / 30$ \\
12 & $01 / 01-02 / 28$ & $03 / 01-04 / 30$ & $05 / 01-06 / 30$ & $07 / 01-08 / 30$ & $08 / 31-10 / 31$ & $11 / 01-12 / 31$ \\
6 & $01 / 01-03 / 31$ & $04 / 01-06 / 30$ & $07 / 01-09 / 30$ & $10 / 01-12 / 31$ & & \\
4 & $01 / 01-04 / 30$ & $05 / 01-08-31$ & $09 / 01-12 / 31$ & & & \\
3 & $01 / 01-06 / 30$ & $07 / 01-12 / 31$ & & & & \\
2 & & & & & &
\end{tabular}

Table 4. Definition of seasons used for uncensored Seasonal Kendall test.-Continued

\begin{tabular}{ccccccc}
\hline Number of & \multicolumn{6}{c}{ Season number } \\
\cline { 2 - 7 } $\begin{array}{c}\text { seasons } \\
\text { per year }\end{array}$ & $\mathbf{7}$ & $\mathbf{8}$ & $\mathbf{9}$ & $\mathbf{1 0}$ & $\mathbf{1 1}$ & $\mathbf{1 2}$ \\
\hline 12 & $07 / 01-07 / 25$ & $07 / 26-08 / 18$ & $08 / 19-09 / 12$ & $09 / 13-10 / 06$ & $10 / 07-10 / 31$ & $11 / 01-12 / 31$ \\
6 & & & & & & \\
4 & & & & & & \\
3 & & & & & & \\
2 & & & & & & \\
\hline
\end{tabular}

the streamflow estimate, effectively creating a flow-adjusted concentration (FAC) value (Schertz and others, 1991). For this study, a locally weighted scatter plot smoothing (LOWESS) technique (Helsel and Hirsch, 2002) was used to develop the FAC values. These FAC values were then tested for possible trends using the uncensored Seasonal Kendall test. For example, the variability of chloride concentration for 2001 through 2005 is shown in figure 6 (fig. 1, number 16). Following the flow-adjustment routine, the effect of flow on chloride concentration is removed, and deviations from normal concentration patterns are more easily observed.

\section{Trend Testing}

The uncensored Seasonal Kendall test is a nonparametric test used to detect possible trends in water-quality constituents over time (Schertz and others, 1991). In contrast to using parametric methods, the nonparametric Seasonal Kendall test does not use the actual concentration for a constituent, but it assigns a rank to each concentration. These ranked concentrations are then compared to other ranked concentrations from the same season. The test makes all possible pair-wise comparisons of the ranked concentrations for the period of record of the constituent being tested. For instance, when later concentrations (in time) have a higher rank, a positive result is recorded; if a later concentration has a lower rank, a negative result is recorded. The test statistic is computed as the difference between the total number of positive and negative results in the record. The cumulative result of the test statistic is then compared to zero. If the test statistic is much greater or lower than zero, the probability of trend in the data is higher.
The p-value generated, on the basis of a standard normal distribution, is used to measure the probability of a detectable trend.

A trend is defined as a change in a single direction (upward/downward) in constituent concentrations over time. For this study, a trend is considered to be statistically significant if the p-value of the trend test for a constituent is less than or equal to 0.10 . The $p$-value is the probability that a detected trend resulted from a chance arrangement of the data, rather than from an actual change in constituent concentration. Therefore, there is a 10-percent chance that a detected trend is an artifact of a chance arrangement of data as opposed to an actual trend in constituent concentrations. The default p-value used for indicating a significant trend in the ESTREND program is a more stringent 0.05 . This study opted to use a larger $p$-value $(0.10)$ so more potential trends could be identified in this initial phase of the data collection. In addition, previous trend research done on Michigan streams used a p-value of 0.05 to identify potential trends. For comparison purposes, it was important to show trends at both p-values of 0.10 and 0.05 .

The magnitude of the detected trend is also estimated using ESTREND. The magnitude is actually the trend slope or the rate at which a concentration is increasing or decreasing over time. This slope is the median slope of all pair-wise comparisons of the concentration data. Each pair-wise difference is divided by the number of years separating the pair of concentrations (Schertz and others, 1991). When the concentration data are $\log$ transformed and flow adjusted in the process of determining a trend (as in this study), the trend slope is best represented as a percent change in concentration. 

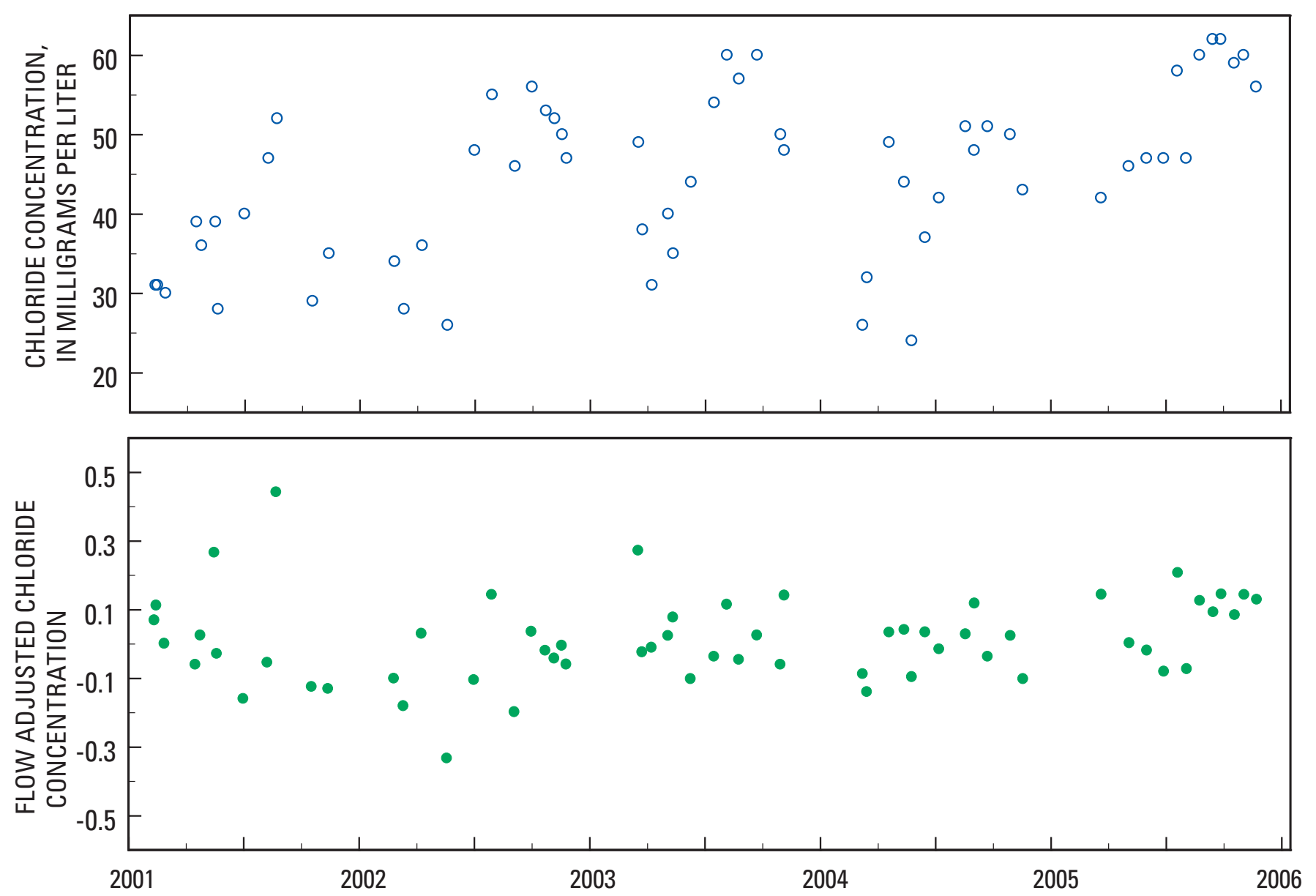

Figure 6. Normal and flow-adjusted concentrations for chloride from 2001 through 2005, Kalamazoo River at New Richmond, Michigan.

\section{Limitations}

Although the data collected as part of this study meet the criteria for using the uncensored Seasonal Kendall test for trends, the use of this data set has some limitations associated with it. Ideally, trend analysis should be performed on a data set collected at a regularly spaced interval throughout the year. Collecting samples on a set schedule avoids introducing temporal bias that may obscure potential trend determination (Schertz and other, 1991). In addition, studies should avoid any planned bias toward any particular level of streamflow (Schertz and others, 1991). For this study, during intensive sampling periods, sample collection was weighted toward high streamflow conditions as opposed to collecting on regularly spaced interval. As a result, there is potential for bias to affect the determination of trends for this study. During the non-intensive phase of sampling for the integrator sites, this was not an issue because samples were collected at a regularspaced interval.

The reason for this distribution of samples in the WCMP was that the MDEQ had two major goals for the tributarymonitoring component: 1 ) to calculate loadings of selected chemical indicators from major Michigan rivers into the Great Lakes, and 2) to measure spatial and temporal trends in contaminant concentrations. The MDEQ recognized that accommodating both goals required compromises in study design. That is, had the only goal been to calculate loads or only to assess trends, the design probably would have been different than the one ultimately adopted. Despite the constraints, the current approach was considered sufficient to satisfy both goals with the recognition that the design should be evaluated after some years of data became available.

To accomplish the first goal, the peer-reviewed study design established for the Lake Michigan Mass Balance Project was followed. Specifically, this protocol called for flow-stratified sampling in which approximately 75 percent of the samples would be collected during high-flow events from the target tributaries in selected years. To meet the second goal, water samples were collected at four pre-determined dates per year, regardless of flow, from each tributary during non-loading years (4 out of every 5 years for most rivers). This approach was based on separate reviews of fixed-station stream/river data from New Jersey and Wisconsin, both of which sample quarterly (New Jersey Department of Environmental Protection, 1998; Team for Evaluating the Wisconsin Water-Monitoring Network, 1998). In particular, Wisconsin concluded that four samples per year were sufficient to detect water-quality trends. 


\section{ESTREND Seasonal Kendall Test Results}

Trend results are reported for 16 constituents sampled at 28 sites throughout Michigan from 1998 to 2005. Statistically significant trends are summarized in table 5 as well as appendix 1. It is important to understand that significant trends may be a result of small changes in constituent concentrations over time. Detected trends should be assessed in the context of the potential effect that a constituent can have on the environment. These trends may be a result of processes that are naturally occurring, anthropogenic, or a combination of both.

\section{Trends for Physical Water Properties}

The major physical properties analyzed for trends were dissolved oxygen, $\mathrm{pH}$, specific conductance, water temperature, turbidity, and total suspended solids. Significant trends were detected for all of these constituents for at least one site. The trends detected for the various physical properties analyzed are listed in table 6.

$\mathrm{DO}$ is a measure of how much oxygen is present in water. Aquatic organisms require oxygen for survival, so as DO declines, the ability to sustain aquatic organisms decreases. Thus, a decrease in DO over time is generally considered a decrease in overall water quality, and the opposite also is true. The trend for DO was upward at three sites: the Tahquamenon River, lower Grand River, and lower St. Joseph River. The magnitudes of these upward trends are 2.7, 3.1, and 3.8 percent per year, respectively (appendix 1).

The $\mathrm{pH}$ scale describes the hydrogen-ion activity in water. Waters with low $\mathrm{pH}$ are considered acidic, and waters with high $\mathrm{pH}$ are considered alkaline. The $\mathrm{pH}$ of a typical stream ranges between 5 and 9 . A pH value of 7 is considered neutral: under natural (unaltered) conditions, however, the $\mathrm{pH}$ of stream water can be slightly acidic or slightly alkaline, depending on local environmental conditions. Trends in $\mathrm{pH}$ need to be evaluated in the context of the starting values at the beginning of the study. If the $\mathrm{pH}$ starts low and has an upward trend or starts high and has a downward trend, water quality could be considered improving. Upward trends in $\mathrm{pH}$ were detected at sites on the lower Muskegon, upper St. Joseph, and the Shiawassee Rivers (table 6). The percent increase per year for $\mathrm{pH}$ was 0.45 for the lower Muskegon River, 0.87 for the upper St. Joseph River, and 0.89 on the Shiawassee River (appendix 1). Despite the increase in $\mathrm{pH}$, the median values for these sites and all others still remain between 9.0 and 6.5, which indicate acceptable water quality with respect to Rule 53 of part 4 of Public Act 451 (Michigan Department of Environmental Quality, 2006b).

Table 5. Summary of trend-analysis results for Michigan study sites, 1999-2005.

\begin{tabular}{|c|c|c|c|c|}
\hline Constituent & $\begin{array}{c}\text { Number of sites } \\
\text { analyzed }\end{array}$ & $\begin{array}{l}\text { Sites with } \\
\text { upward trend }\end{array}$ & $\begin{array}{c}\text { Sites with } \\
\text { downward trend }\end{array}$ & Sites with no trend \\
\hline \multicolumn{5}{|c|}{ Major chemical constituents and physical properties } \\
\hline Chloride & 28 & 7 & 1 & 20 \\
\hline Dissolved oxygen & 28 & 3 & 0 & 25 \\
\hline $\mathrm{pH}$ & 28 & 3 & 0 & 25 \\
\hline Turbidity & 23 & 0 & 3 & 20 \\
\hline Specific conductance & 28 & 1 & 1 & 26 \\
\hline Total suspended solids & 15 & 1 & 0 & 14 \\
\hline Water temperature & 28 & 0 & 1 & 27 \\
\hline \multicolumn{5}{|c|}{ Nutrients } \\
\hline Nitrite & 26 & 5 & 1 & 20 \\
\hline Ammonia & 24 & 1 & 3 & 20 \\
\hline Phosphorus & 27 & 1 & 2 & 24 \\
\hline Total Kjeldahl nitrogen & 28 & 1 & 2 & 25 \\
\hline Nitrate & 25 & 0 & 1 & 24 \\
\hline \multicolumn{5}{|c|}{ Trace metals } \\
\hline Chromium & 24 & 0 & 6 & 18 \\
\hline Copper & 28 & 6 & 0 & 22 \\
\hline Lead & 28 & 1 & 2 & 25 \\
\hline Mercury & 28 & 1 & 0 & 27 \\
\hline
\end{tabular}


Table 6. Trends for various physical properties analyzed at Michigan stream sites, 1999-2005.

$[\boldsymbol{\Lambda}$, increasing trend with p-value less than or equal to $0.05 ; \Delta$, increasing trend with p-value greater than 0.05 but less than 0.10 ; $\mathbf{\nabla}$, decreasing trend with p-value less than or equal to $0.05 ; \nabla$, decreasing trend with p-value greater than 0.05 but less than $0.10 ;-$, no trend detected; NA, trend not tested because of data limitations]

\begin{tabular}{|c|c|c|c|c|c|c|c|}
\hline $\begin{array}{c}\text { Watershed } \\
\text { number }\end{array}$ & Site & $\begin{array}{c}\text { Dissolved } \\
\text { oxygen }\end{array}$ & $\mathrm{pH}$ & Turbidity & $\begin{array}{c}\text { Specific } \\
\text { conductance }\end{array}$ & $\begin{array}{l}\text { Total suspended } \\
\text { solids }\end{array}$ & $\begin{array}{c}\text { Water } \\
\text { temperature }\end{array}$ \\
\hline 1 & Ontonagon River at Ontonagon & - & - & - & - & - & - \\
\hline 2 & Menominee River at Menominee & - & - & - & - & NA & - \\
\hline 3 & Escanaba River at Wells & - & - & - & - & NA & - \\
\hline 4 & Sturgeon River at Nahma & - & - & $\nabla$ & - & NA & - \\
\hline 5 & Manistique River above Manistique & - & - & NA & - & NA & - \\
\hline 6 & Tahquamenon River at Emerson & $\Delta$ & - & - & - & NA & $\nabla$ \\
\hline 7 & Pine River near Charles & - & - & - & - & - & - \\
\hline 8 & Cheboygan River at Cheboygan & - & - & NA & - & NA & - \\
\hline 9 & Boardman River near Traverse City & NA & NA & NA & NA & NA & NA \\
\hline 10 & Manistee River at Parkdale & - & - & - & - & $\Delta$ & - \\
\hline 11 & Pere Marquette River at Scottville & - & - & NA & - & NA & - \\
\hline 12 & Muskegon River near Bridgeton & - & $\Delta$ & NA & - & NA & - \\
\hline 13 & Muskegon River near Hersey & - & - & - & - & NA & - \\
\hline 14 & Grand River near Eastmanville & $\Delta$ & - & - & - & - & - \\
\hline 15 & Grand River at Ionia & - & - & - & - & - & - \\
\hline 16 & Kalamazoo River at New Richmond & - & - & - & - & - & - \\
\hline 17 & Kalamazoo River near Augusta & - & - & - & - & NA & - \\
\hline 18 & St. Joseph River at St. Joseph & $\Delta$ & - & - & - & - & - \\
\hline 19 & St. Joseph River at Mottville & - & $\Delta$ & - & - & NA & - \\
\hline 20 & River Raisin at Monroe & - & - & - & $\Delta$ & - & - \\
\hline 21 & Huron River at Rockwood & - & - & - & - & - & - \\
\hline 22 & River Rouge at River Rouge & - & - & - & - & - & - \\
\hline 23 & Clinton River at Mt. Clemens & - & - & - & - & - & - \\
\hline 24 & Black River at Port Huron & - & - & - & - & - & - \\
\hline 25 & Flint River near Fosters & - & - & - & - & - & - \\
\hline 26 & Cass River near Bridgeport & - & - & - & - & - & - \\
\hline 27 & Shiawassee River near Fergus & - & $\Delta$ & $\nabla$ & - & NA & - \\
\hline 28 & Tittabawassee River near Saginaw & - & - & $\nabla$ & $\nabla$ & - & - \\
\hline 29 & Saginaw River at Essexville & NA & NA & NA & NA & NA & NA \\
\hline 30 & Au Sable River near Au Sable & - & - & NA & - & NA & - \\
\hline 31 & Thunder Bay at Alpena & NA & NA & NA & NA & NA & NA \\
\hline
\end{tabular}


Specific conductance describes the ability of a substance to conduct an electrical current. In water, there is a direct relation between specific conductance and the amount of dissolved ions present. Significant trends were detected at two sites, one an upward trend and one a downward trend. An upward trend of 5.66 percent per year was detected for the River Raisin site (appendix 1). A downward trend of 1.74 percent per year was detected for the Tittabawassee River site (appendix 1).

Turbidity is used to describe the clarity of water associated with how much suspended particulate matter is in the water. High turbidity values indicate a decrease in water clarity or an increase in the amount of suspended particulates in the water. High turbidity commonly is associated with poor water quality (Gray and Glysson, 2003). Downward trends were detected at sites on the Shiawassee, Tittabawassee, and Sturgeon Rivers (table 6). The magnitude of the downward trends at these sites is $16.3,16.3$, and 4.59 percent per year, respectively. No trends were detected at several sites where turbidity measured greater than 100 NTU (Grand River, Pine River, Clinton River, Flint River, River Raisin, Ontonagon River, and St. Joseph River). Even though there are no waterquality criteria for turbidity, turbidity is highly correlated to some other constituents, specifically, those that are transported in particulate or colloid form. So that as turbidity increases, so does the likelihood of these other constituent concentrations being increased and transported in these systems (Gray and Glysson, 2003).

Water temperature was another physical property measured as part of this study. A significant trend was detected at 1 of the 28 sites sampled. A downward trend in temperature of 4.67 percent per year was detected at the Tahquamenon River (appendix 1).

TSS is similar to turbidity; however, this suspended material is measured by filtering a water sample and drying the filter to determine how much sediment gets filtered out. Similar to turbidity, high TSS typically is related to poor water quality. TSS concentrations usually are correlated with increased streamflow. A significant trend was detected at one site. An upward trend of 10.37 percent per year was detected at the Manistee River (appendix 1). Despite the upward trend in TSS for the Manistee River, the TSS concentration at this site was in the $25^{\text {th }}$ percentile for all sites analyzed in the WCMP; the median TSS concentration was $10 \mathrm{mg} / \mathrm{L}$. The Clinton, Pine, Flint, Grand, Cass, and Kalamazoo Rivers had median concentrations twice as high (greater than $20 \mathrm{mg} / \mathrm{L}$ ). Because contaminants commonly are bound to these particles, high TSS values may indicate an increased probability of chemical contamination as well. The relation between TSS and other water-quality constituents is evaluated in more detail later in this report.

\section{Trends in Chloride Concentrations}

More sites had trends for chloride than any other constituent. Several potential sources of chloride exist in the environment. These sources may be naturally occurring like basin brines and dissolution of evaporite deposits (rock salt) or sources may be anthropogenic like road-deicing compounds and wastewater effluent. An increase in chloride is generally considered a decrease in water quality. Significant chloride trends were detected at eight sites; seven were upward trends and one was a downward trend (table 7). The seven sites with upward trends in chloride are on the upper and lower St. Joseph, upper Muskegon, lower Kalamazoo, Shiawassee, Menominee, and Clinton Rivers. The magnitudes of the trends detected at these seven sites are 2.62, 1.56, 6.34, 3.28, 3.76, 3.94 , and 4.63 , respectively (appendix 1). The only downward trend detected for chloride was at the site on the Escanaba River, which had a downward trend of 9.35 percent per year (appendix 1).

Chloride concentration in most streams varies temporally. By examining chloride data at the intensively monitored sites, it can be seen that chloride concentrations at a given site increase and decrease periodically through the year (fig. 7). The degree of change is largest at sites with the highest chloride concentrations. There does not appear to be a similar pattern among these five sites, which suggests site-specific variables control the chloride concentration in the water. Chloride concentrations were inversely related to mean daily streamflow (fig. 8) at seven of the eight sites where a trend was detected. For the Clinton, Escanaba, Menominee, Shiawassee, Kalamazoo, and lower St. Joseph River sites, the highest concentrations of chloride typically were measured in July, August, and September when daily streamflow was lowest.

Even though most trends for chloride concentrations in Michigan stream waters were upward, it is important to relate the observed chloride concentrations to water-quality criteria. The State of Michigan does not have a water-quality standard for chloride; however, the U.S. Environmental Protection Agency (USEPA) lists concentrations of chloride of 230 and $860 \mathrm{mg} / \mathrm{L}$ for chronic and acute aquatic-life toxicity benchmarks, respectively (U.S. Environmental Protection Agency, 1988). Throughout the study, the chronic aquatic-life toxicity criterion of $230 \mathrm{mg} / \mathrm{L}$ was exceeded eight times, and the acute aquatic-life toxicity criterion of $860 \mathrm{mg} / \mathrm{L}$ was never exceeded. All the samples greater than $230 \mathrm{mg} / \mathrm{L}$ were collected in urban areas in 2003-2005 during the months of March and April: five samples from the Clinton River site, two samples from the River Rouge site, and one sample from the Flint River site. These high chloride concentrations appear to be isolated events, and the long-term effect on these streams would require further evaluation to determine if increased chloride is a water-quality concern. 
Table 7. Trend results for chloride at Michigan stream sites, 1999-2005.

$[\mathbf{\Lambda}$, increasing trend with $p$-value less than or equal to $0.05 ; \Delta$, increasing trend with $\mathrm{p}$-value greater than 0.05 but less than $0.10 ; \boldsymbol{\nabla}$, decreasing trend with p-value less than or equal to $0.05 ; \nabla$, decreasing trend with p-value greater than 0.05 but less than $0.10 ;-$, no trend detected; $\mathrm{NA}$, trend not tested because of data limitations]

\begin{tabular}{|c|c|c|}
\hline $\begin{array}{c}\text { Watershed } \\
\text { number }\end{array}$ & Site & Chloride \\
\hline 1 & Ontonagon River at Ontonagon & - \\
\hline 2 & Menominee River at Menominee & $\Delta$ \\
\hline 3 & Escanaba River at Wells & $\nabla$ \\
\hline 4 & Sturgeon River at Nahma & - \\
\hline 5 & Manistique River above Manistique & - \\
\hline 6 & Tahquamenon River at Emerson & - \\
\hline 7 & Pine River near Charles & - \\
\hline 8 & Cheboygan River at Cheboygan & - \\
\hline 9 & Boardman River near Traverse City & NA \\
\hline 10 & Manistee River at Parkdale & - \\
\hline 11 & Pere Marquette River at Scottville & - \\
\hline 12 & Muskegon River near Bridgeton & - \\
\hline 13 & Muskegon River near Hersey & $\Delta$ \\
\hline 14 & Grand River near Eastmanville & - \\
\hline 15 & Grand River at Ionia & - \\
\hline 16 & Kalamazoo River at New Richmond & $\mathbf{\Delta}$ \\
\hline 17 & Kalamazoo River near Augusta & - \\
\hline 18 & St. Joseph River at St. Joseph & $\Delta$ \\
\hline 19 & St. Joseph River at Mottville & $\Delta$ \\
\hline 20 & River Raisin at Monroe & - \\
\hline 21 & Huron River at Rockwood & - \\
\hline 22 & River Rouge at River Rouge & - \\
\hline 23 & Clinton River at Mt. Clemens & $\Delta$ \\
\hline 24 & Black River at Port Huron & - \\
\hline 25 & Flint River near Fosters & - \\
\hline 26 & Cass River near Bridgeport & - \\
\hline 27 & Shiawassee River near Fergus & $\Delta$ \\
\hline 28 & Tittabawassee River near Saginaw & - \\
\hline 29 & Saginaw River at Essexville & NA \\
\hline 30 & Au Sable River near Au Sable & - \\
\hline 31 & Thunder Bay at Alpena & NA \\
\hline
\end{tabular}

Figure 7. Chloride concentrations over time for selected intensively monitored stream sites in Michigan, 1999 through 2005.





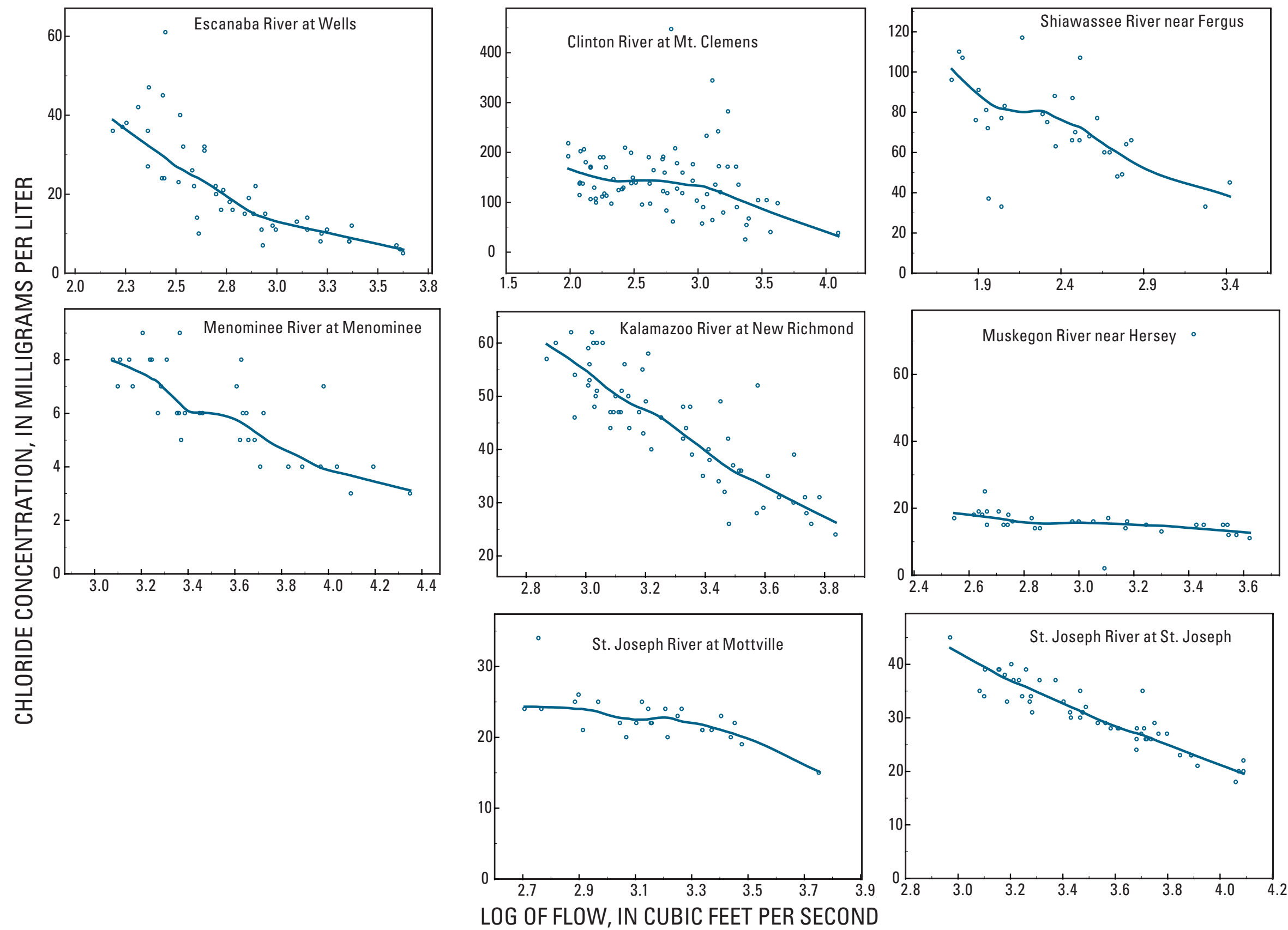

Figure 8. The relation between chloride concentration and streamflow at selected stream sites in Michigan, 1999 through 2005. 


\section{Trends in Nutrient Concentrations}

The constituents, commonly referred to as nutrients, analyzed for trends in this study were nitrite, ammonia, phosphorus, TKN, and nitrate. Phosphorus and nitrogen species may come from a variety of sources including wastewater effluent, common fertilizers, and atmospheric byproducts of combustion. Generally, high concentrations of nutrients are linked to degraded water quality, because these nutrients lead to increased algal growth and potentially to eutrophication of water bodies.

\section{Nitrogen}

Nitrogen compounds are part of a large cycle involving the production and breakdown of nitrogen gas $\left(\mathrm{N}_{2}\right)$, nitrite, nitrate, or ammonia compounds (fig. 9). Nitrogen-fixing bacteria in soils can take nitrogen gas and convert it to a form of nitrogen usable by plants. As plants die, ammonia is produced as a result of their decay. This ammonia is then used by bacteria to form nitrite, which in turn is transformed to nitrate by a different group of bacteria, and the cycle continues. Fertilizers commonly are applied in the form of nitrate to encourage plant growth. If fertilizers are applied in excess of plant needs, the excess can run off into streams or dissolve into groundwater and enter streams through base flow. In addition, wastewatertreatment practices may discharge large amounts of organic nitrogen and ammonia into the environment (not shown in figure 9).

The recommended water-quality criteria for total nitrogen compounds in surface waters are dependent on the ecoregion in which the stream is located. Michigan is comprised of three different USEPA Ecoregional level III Ecoregions (U.S. Environmental Protection Agency, 2000). With the exception of the Traverse Bay Watershed, most of the northern Lower Peninsula and the entire Upper Peninsula was categorized as Ecoregion VIII. Most of the central and southern Lower Peninsula, including the Traverse Bay Watershed, makes up Ecoregion VII. The Saginaw Bay Watershed and Lake Erie Watershed areas are characterized as Ecoregion VI. Each ecoregion has a USEPA recommended water-quality criteria for nutrients specific to that ecoregion (U.S. Environmental Protection Agency, 2002, table 8). These criteria were developed as guid-

Table 8. Water-quality criteria for total phosphorus and total nitrogen for U.S. Environmental Protection Agency ecoregions in Michigan.

[USEPA, U.S. Environmental Protection Agency; mg/L, miligrams per liter]

\begin{tabular}{lcc}
\hline USEPA ecoregion & $\begin{array}{c}\text { Total phosphorus } \\
\text { (mg/L) }\end{array}$ & $\begin{array}{c}\text { Total nitrogen } \\
\text { (mg/L) }\end{array}$ \\
\hline VI & 0.076 & 2.18 \\
VII & 0.033 & 0.54 \\
VIII & 0.01 & 0.38 \\
\hline
\end{tabular}

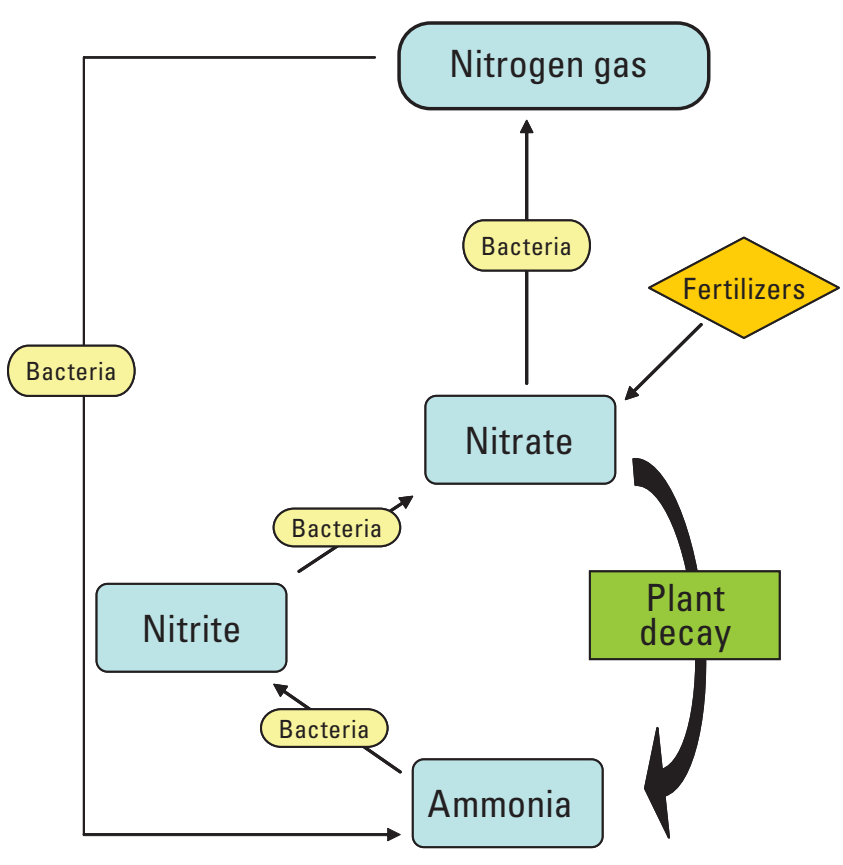

Figure 9. Schematic representation of the nitrogen cycle. (Wastewater discharge and organic nitrogen not shown.)

ance on a national scale to reduce or prevent eutrophication of the nation's water. Michigan is in the process of developing state nutrient criteria for future use.

Total nitrogen (TN) concentrations include the sum of TKN, nitrate, and nitrite. The recommended TN criterion was exceeded on the basis of the nitrate concentration alone in approximately 19 percent of the samples. Only the Cheboygan and Au Sable River sites met TN criteria for all samples. Median nitrate concentrations exceeded the recommended Ecoregion TN criteria at the Kalamazoo, Grand, Raisin, Cass, Flint, St. Joseph, Black, Shiawassee, and Clinton River sites.

Trends for nitrite were the most commonly detected trends of the different nutrients tested (table 9). Five sites had upward trends, and one site had a downward trend. The upward nitrite trends at the Manistee, Clinton, upper Muskegon, Black, and Ontonagon River sites are 4.2, 10.9, 13.1, 19.9, and 24.8 percent per year, respectively (appendix 1). The Au Sable River site had a downward trend of 0.02 percent per year (appendix 1).

Trends in ammonia were detected at four sites (table 9). The lower Grand River site had an upward trend of 5.9 percent per year (appendix 1). The other three sites that had downward trends were the Shiawassee, upper St. Joseph, and Manistique Rivers. The magnitudes of the downward trends were 18.6, 9.8, and 8.8 percent per year, respectively (appendix 1).

TKN is defined as the concentration of the sum of organic nitrogen, ammonia, and ammonium ion in solution. An upward trend of 4.55 percent per year was detected at the Clinton River site (table 9) (appendix 1). Downward trends of 3.7 and 2.9 percent per year were detected at sites on the Tittabawassee and Manistique Rivers, respectively (appendix 1). 
Table 9. Trend results for nutrients at Michigan stream sites, 1999-2005.

$[\boldsymbol{\Lambda}$, increasing trend with p-value less than or equal to $0.05 ; \Delta$, increasing trend with p-value greater than 0.05 but less than 0.10 ; $\boldsymbol{\nabla}$, decreasing trend with $p$-value less than or equal to $0.05 ; \nabla$, decreasing trend with $\mathrm{p}$-value greater than 0.05 but less than $0.10 ;-$, no trend detected; NA, trend not tested because of data limitations]

\begin{tabular}{|c|c|c|c|c|c|c|}
\hline $\begin{array}{l}\text { Watershed } \\
\text { number }\end{array}$ & Site & $\begin{array}{l}\text { Total Kjeldahl } \\
\text { nitrogen }\end{array}$ & Ammonia & Nitrite & Nitrate & Phosphorus \\
\hline 1 & Ontonagon River at Ontonagon & - & - & $\Delta$ & NA & - \\
\hline 2 & Menominee River at Menominee & - & - & - & - & - \\
\hline 3 & Escanaba River at Wells & - & - & - & - & - \\
\hline 4 & Sturgeon River at Nahma & - & - & - & - & - \\
\hline 5 & Manistique River above Manistique & $\nabla$ & $\nabla$ & - & - & - \\
\hline 6 & Tahquamenon River at Emerson & - & - & - & - & - \\
\hline 7 & Pine River near Charles & - & - & NA & NA & - \\
\hline 8 & Cheboygan River at Cheboygan & - & - & NA & NA & NA \\
\hline 9 & Boardman River near Traverse City & NA & NA & NA & NA & NA \\
\hline 10 & Manistee River at Parkdale & - & - & $\Delta$ & - & $\Delta$ \\
\hline 11 & Pere Marquette River at Scottville & - & - & - & - & $\nabla$ \\
\hline 12 & Muskegon River near Bridgeton & - & - & - & - & - \\
\hline 13 & Muskegon River near Hersey & - & - & $\Delta$ & - & - \\
\hline 14 & Grand River near Eastmanville & - & $\Delta$ & - & - & - \\
\hline 15 & Grand River at Ionia & - & - & - & - & - \\
\hline 16 & Kalamazoo River at New Richmond & - & - & - & - & - \\
\hline 17 & Kalamazoo River near Augusta & - & - & - & - & - \\
\hline 18 & St. Joseph River at St. Joseph & - & - & - & - & - \\
\hline 19 & St. Joseph River at Mottville & - & $\nabla$ & - & - & - \\
\hline 20 & River Raisin at Monroe & - & NA & - & - & - \\
\hline 21 & Huron River at Rockwood & - & - & - & - & - \\
\hline 22 & River Rouge at River Rouge & - & - & - & - & - \\
\hline 23 & Clinton River at Mt. Clemens & $\Delta$ & - & $\Delta$ & $\nabla$ & - \\
\hline 24 & Black River at Port Huron & - & NA & $\Delta$ & - & - \\
\hline 25 & Flint River near Fosters & - & NA & - & - & - \\
\hline 26 & Cass River near Bridgeport & - & NA & - & - & - \\
\hline 27 & Shiawassee River near Fergus & - & $\nabla$ & - & - & - \\
\hline 28 & Tittabawassee River near Saginaw & $\nabla$ & - & - & - & $\nabla$ \\
\hline 29 & Saginaw River at Essexville & NA & NA & NA & NA & NA \\
\hline 30 & Au Sable River near Au Sable & - & - & $\nabla$ & - & - \\
\hline 31 & Thunder Bay at Alpena & NA & NA & NA & NA & NA \\
\hline
\end{tabular}


Only the Clinton River site had a significant downward trend in nitrate with a magnitude of 2.57 percent per year. The Clinton River at Mt. Clemens sampling site is in an urban setting downstream of major permitted wastewater discharges. In the headwaters of the Clinton River Watershed, the land use is more agriculture and residential. This sampling site, close to the mouth of the Clinton River, is influenced locally by heavy urbanization but also is affected by upstream agricultural and residential inputs. Despite a downward trend in nitrate, the Clinton River did show upward trends in concentrations of nitrite and TKN. Median concentrations for TKN, nitrate, and nitrite at this site were $1.03,1.57$, and $0.039 \mathrm{mg} / \mathrm{L}$ as nitrogen, respectively. Therefore, even though the downward nitrate trend appears to be an improvement, the TN concentration at this site is still a concern. High concentrations of TKN commonly are measured in wastewater effluent. If wastewater effluent were the primary contributor of TKN at this site, the highest concentrations would be expected during lower streamflow. This is not the case (fig. 10); TKN peaks correspond to increases in streamflow.

In contrast to $\mathrm{TKN}$, the peaks in nitrate concentration correspond to decreases in streamflow (fig. 11). TKN and ammonia are not very mobile and commonly are attached to particles introduced into surface water from runoff or direct discharge of waste into streams. However, nitrate and nitrite are easily dissolved and are very mobile in surface and groundwater. Because nitrate and nitrite are by-products of TKN degradation, they come from the same source but differ in their transport mechanism.

Although there was no statistical trend for TSS, there does appear to be a relation between the concentrations of TKN and nitrate and the amount of TSS for the Clinton River sampling site (fig. 12). TKN increases with increased TSS and nitrate decreases with increased TSS. There is also a direct relation between daily streamflow and TSS at this site (fig. 13). This relation suggests that the increased concentrations of TKN are a result of increased runoff during precipitation events in the watershed. These precipitation events lead to high streamflow that dilute nitrate concentrations in the water. The high flows may also lead to increased sediment load to the stream from erosion or resuspension of bed sediment. This might also indicate that nitrate concentrations are either associated with groundwater discharging to the stream and (or) direct discharge of wastewater effluent.

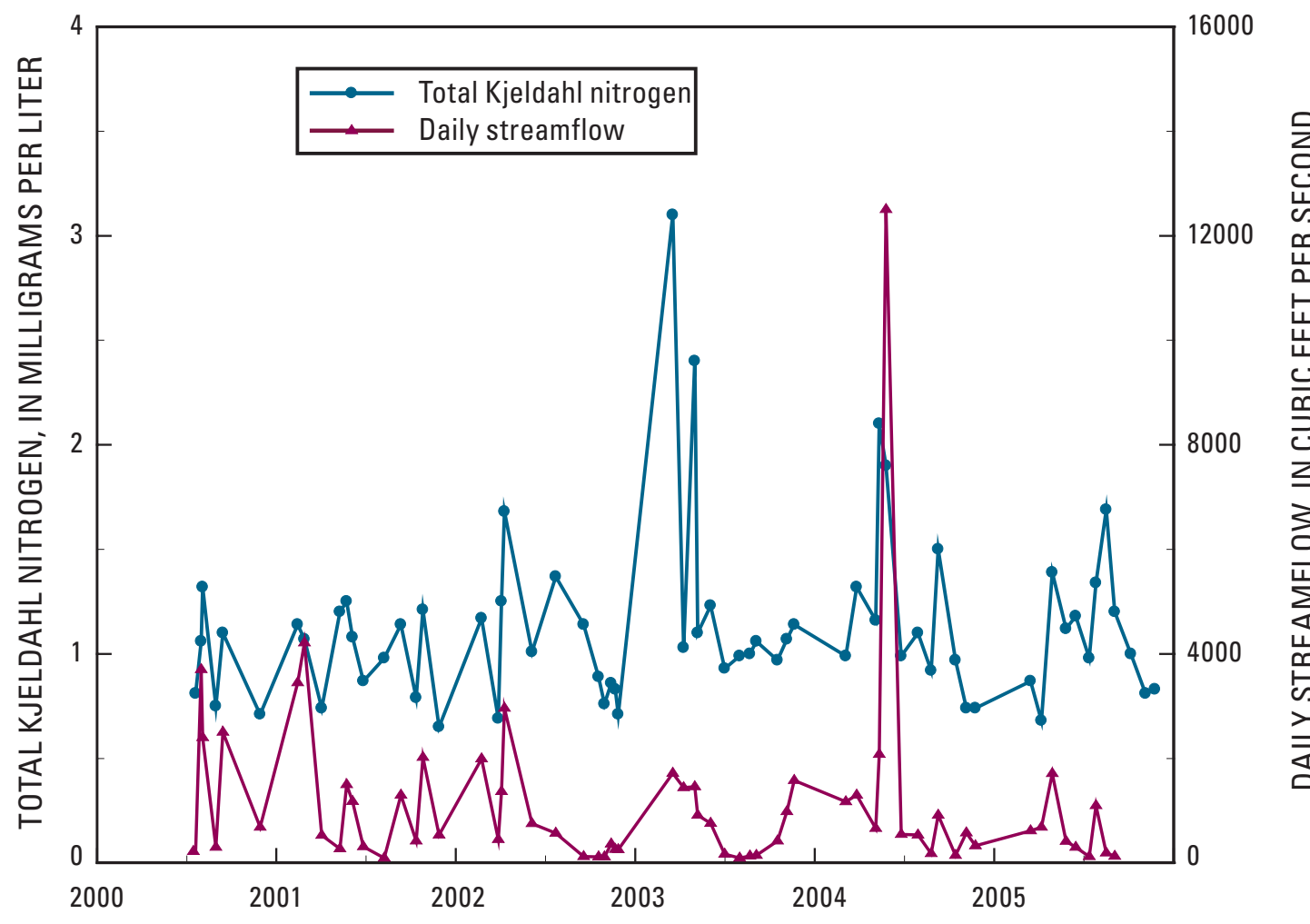

Figure 10. Concentration of Total Kjeldahl nitrogen and streamflow, 2000 through 2005, Clinton River, Michigan. 


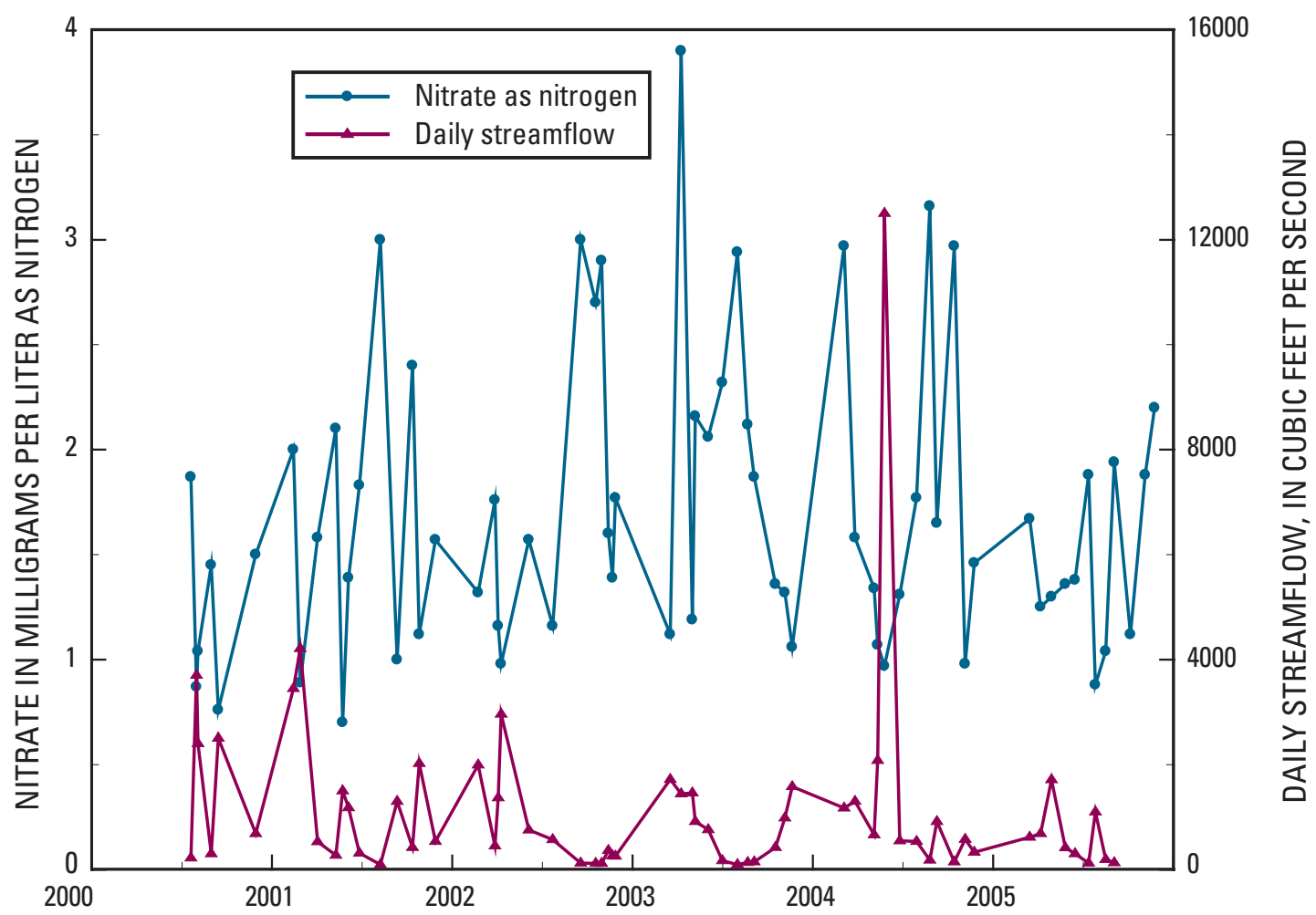

Figure 11. Concentration of nitrate and streamflow, 2000 through 2005, Clinton River, Michigan.

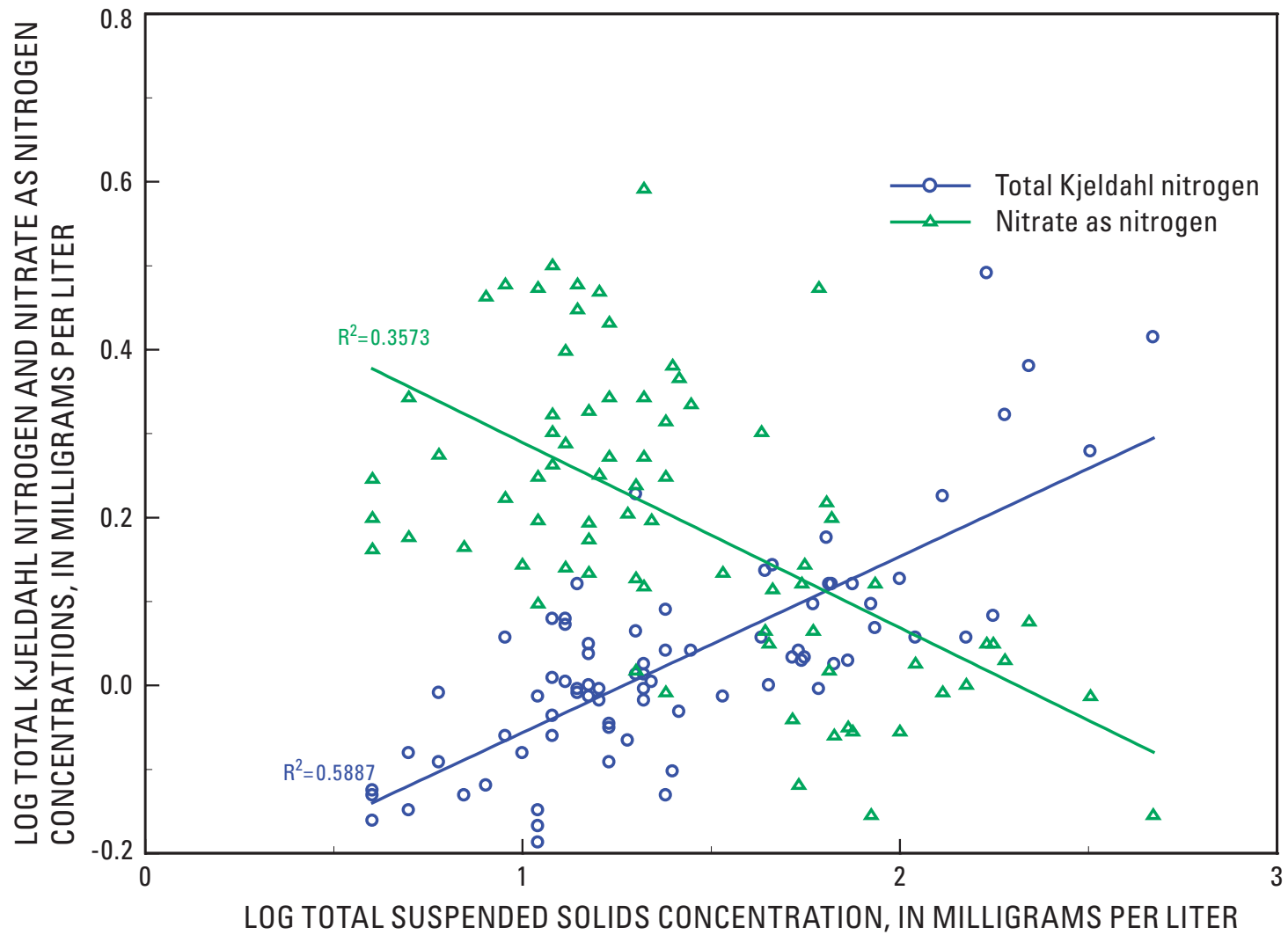

Figure 12. The relations between concentrations of total Kjeldahl nitrogen and nitrate and total suspended solids for the Clinton River, Michigan. 


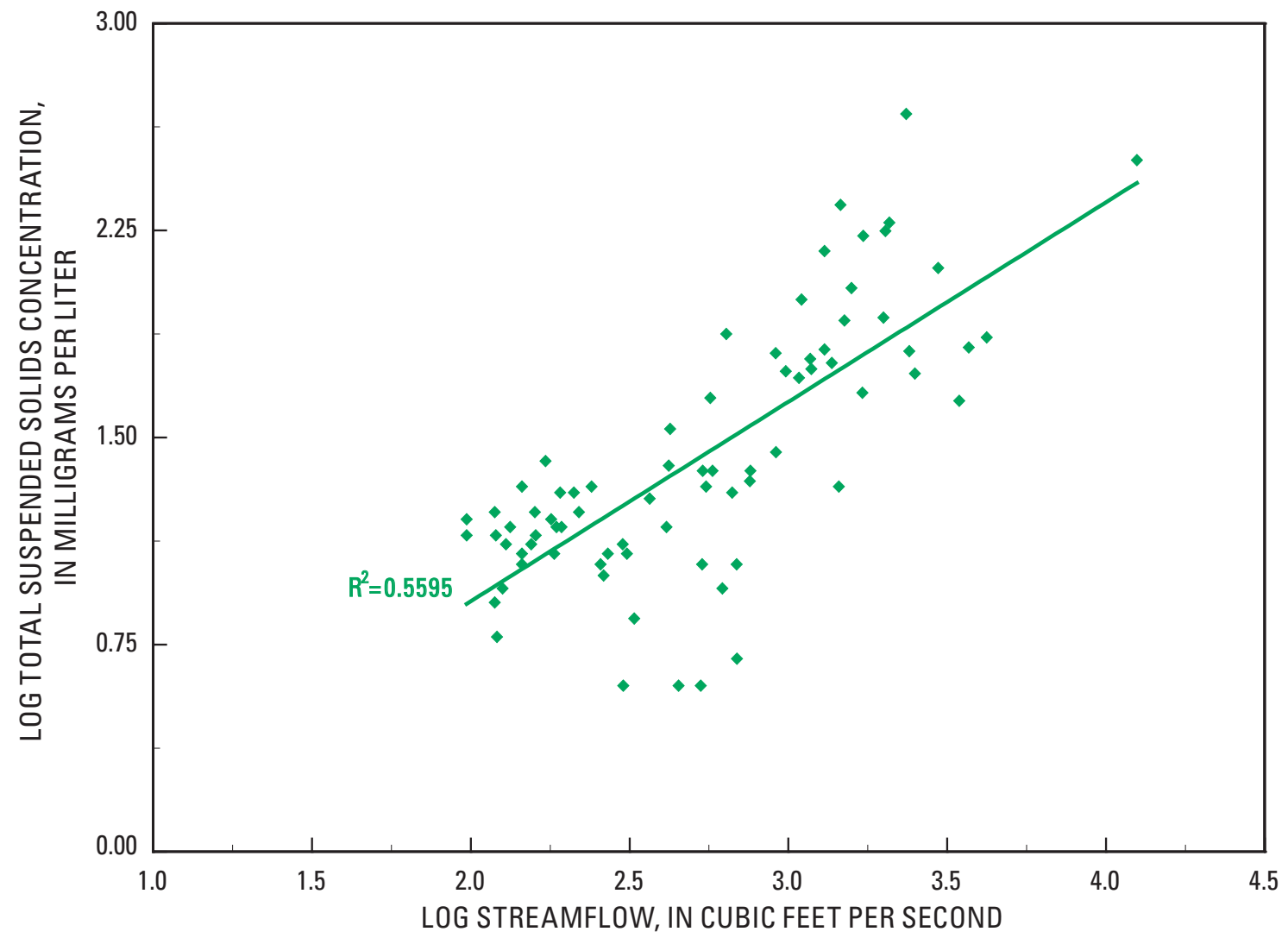

Figure 13. The relation between total suspended solids and streamflow for the Clinton River, Michigan.

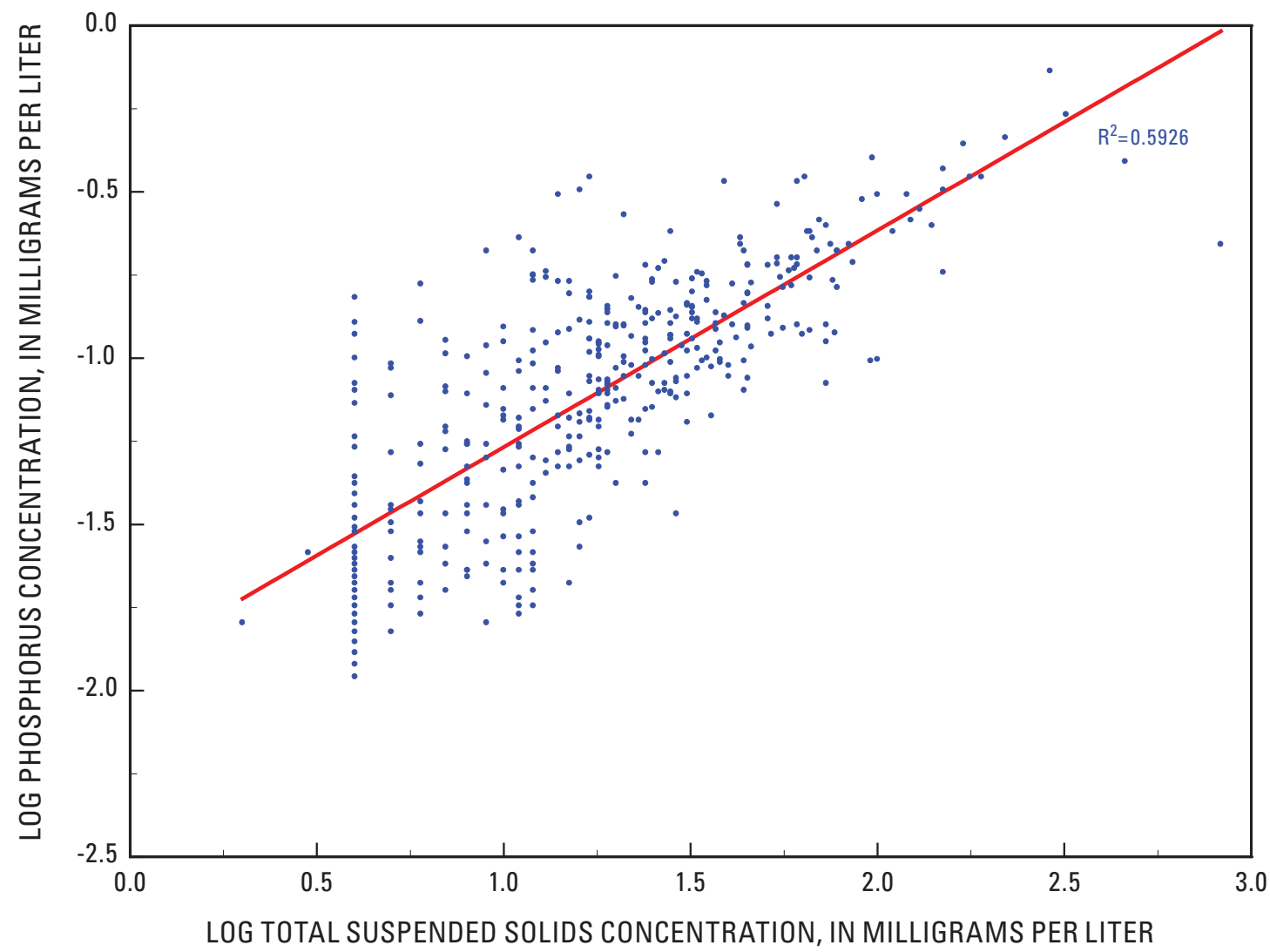

Figure 14. Relation between concentration of phosphorus and total suspended solids in selected Michigan streams. 


\section{Phosphorus}

Like nitrogen, high levels of phosphorus can cause excessive growth of undesirable plants and algae, which lead to water-quality degradation. The USEPA recommended criteria for TP in streams for USEPA Ecoregions in Michigan are shown in table 8. Like TN, TP concentrations in samples collected for the WCMP exceeded the recommended criteria approximately 33 percent of the time. Ten sites consistently exceeded the TP criteria: the Manistee River, Tahquamenon River, Pine River, St. Joseph River (2 sites), Cass River, Grand River (2 sites), Flint River, and Clinton River. Significant trends in phosphorus were detected at three sites across the state. One site had an upward trend, and two sites had downward trends. An upward trend in phosphorus of 4.28 percent per year was detected at the Manistee River site (appendix 1). Downward phosphorus trends were detected at the Tittabawassee River and Pere Marquette River sites with magnitudes of 7.2, and 5.9 percent per year, respectively (appendix 1, table 9).

Common sources of phosphorus include weathering of natural soils and rocks, runoff of excess fertilizer applications (agricultural and residential), and municipal wastewater discharges. Phosphorus is easily sorbed to soil particles such as sediment; therefore, phosphorus concentrations are usually directly related to TSS concentrations. As shown in figure 14 , TSS and phosphorus are positively correlated indicating phosphorus is typically associated with and transported by particulates at the 10 sites that exceed the TP criteria. This may be from land-surface runoff in agriculture areas or wastewater discharges from urban areas. Interestingly, even though concentrations are generally lower at sites in less-developed areas (little agricultural or urban inputs), these sites occasionally have observed concentrations that exceed recommended criteria, suggesting a possible geologic or wildlife component to phosphorus in Michigan streams.

\section{Trends in Trace Metals Concentrations}

Four trace metals - chromium, copper, lead, and mercury - were analyzed for trends in this study. Trace metals generally are associated with industrial waste, but sources also may include wastewater effluent as well as atmospheric deposition, in the case of mercury. Generally, an increase in concentrations of trace metals indicates a decline in water quality.

Statistically significant downward trends for chromium were detected at six sites (table 10). Trends were detected at sites on the Escanaba, Shiawassee, lower St. Joseph, lower Kalamazoo, lower Grand, and Tahquamenon Rivers. The magnitudes of the downward trends were 17.8, 16.1, 13.8, 13.3, 13.5 , and 11.2 percent per year, respectively (appendix 1 ). The highest chromium concentration detected $(32.7 \mu \mathrm{g} / \mathrm{L})$ was at the Clinton River site.
Upward trends for copper were detected at six sites across the state (table 10), at the lower St. Joseph, upper and lower Muskegon, Sturgeon, Rouge, and Au Sable Rivers. Magnitudes of the upward trends detected for copper at these sites were $3.4,6.7,4.8,5.3,8.8$, and 14.1 percent per year, respectively (appendix 1).

The estimated trends may not be unusual, because copper is an abundant and naturally occurring element in the Earth's crust. Copper is essential to all plants and animals; however, high concentrations of copper can be toxic to aquatic life (U.S. Environmental Protection Agency, 2007). Copper can be introduced to streams from mining practices, discharge of municipal wastes, addition to animal feeds for disease prevention, and also as a pesticide for the control of plant pathogens (such as Dutch Elm disease), algae, and slugs (Extension Toxicology Network, 1996).

Trends in lead concentrations were detected at three sites (table 10). One trend was upward, and the other two were downward. An upward trend of 5.49 percent per year was detected at the Manistee River site (appendix 1). However, the highest concentration measured at this site was only 0.298 $\mu \mathrm{g} / \mathrm{L}$ (appendix 1). The downward trends were detected at the Shiawassee and Menominee River sites with magnitudes of 8.6 and 5.6 percent per year, respectively (appendix 1).

Only one significant trend was detected for mercury (table 10). This trend was an upward trend of 9.63 percent per year detected at the Ontonagon River site (appendix 1). The median mercury concentration, for 21 of the 28 sites, was greater than $1.3 \mathrm{ng} / \mathrm{L}$ (Michigan Department of Environmental Quality, 2007). Sources of mercury contamination include wastewater discharges particularly from industrial areas and also atmospheric deposition.

\section{Spatial Distribution of Trends}

One of the primary objectives of the WCMP is to determine the status of water quality throughout Michigan. Most of the WCMP sampling sites are at the mouths of major watersheds and are useful for indicating water-quality conditions for individual watersheds. However, comparison of constituent trends between watersheds is useful to determine if there were any spatial water-quality patterns throughout the state (figs. 15-18).

Several trends were detected in watersheds that drain into Lake Michigan. Chloride concentrations appear to be increasing in the St. Joseph and Kalamazoo River watersheds in the southwestern part of the state (fig. 16). One potential source of chloride in the St. Joseph and Kalamazoo River watersheds is that this region receives substantial amounts of lake-effect snowfall in the winter months, which might indicate increased road-salt application and runoff. DO is also increasing for two watersheds in western Michigan (fig. 15). In contrast, increasing DO is an indicator that water quality is improving in these watersheds. Also, there appears to be a decrease in chromium for most of the western Michigan watersheds (fig. 18). The possible cause for this decrease is uncertain at this time. 
Table 10. Trend results for trace metals at selected Michigan stream sites, 1999-2005.

$[\boldsymbol{\Delta}$, increasing trend with $\mathrm{p}$-value less than or equal to $0.05 ; \boldsymbol{\Delta}$, increasing trend with $\mathrm{p}$-value greater than 0.05 but less than $0.10 ; \boldsymbol{\nabla}$, decreasing trend with p-value less than or equal to $0.05 ; \nabla$, decreasing trend with p-value greater than 0.05 but less than $0.10 ;-$, no trend detected; NA, trend not tested because of data limitations]

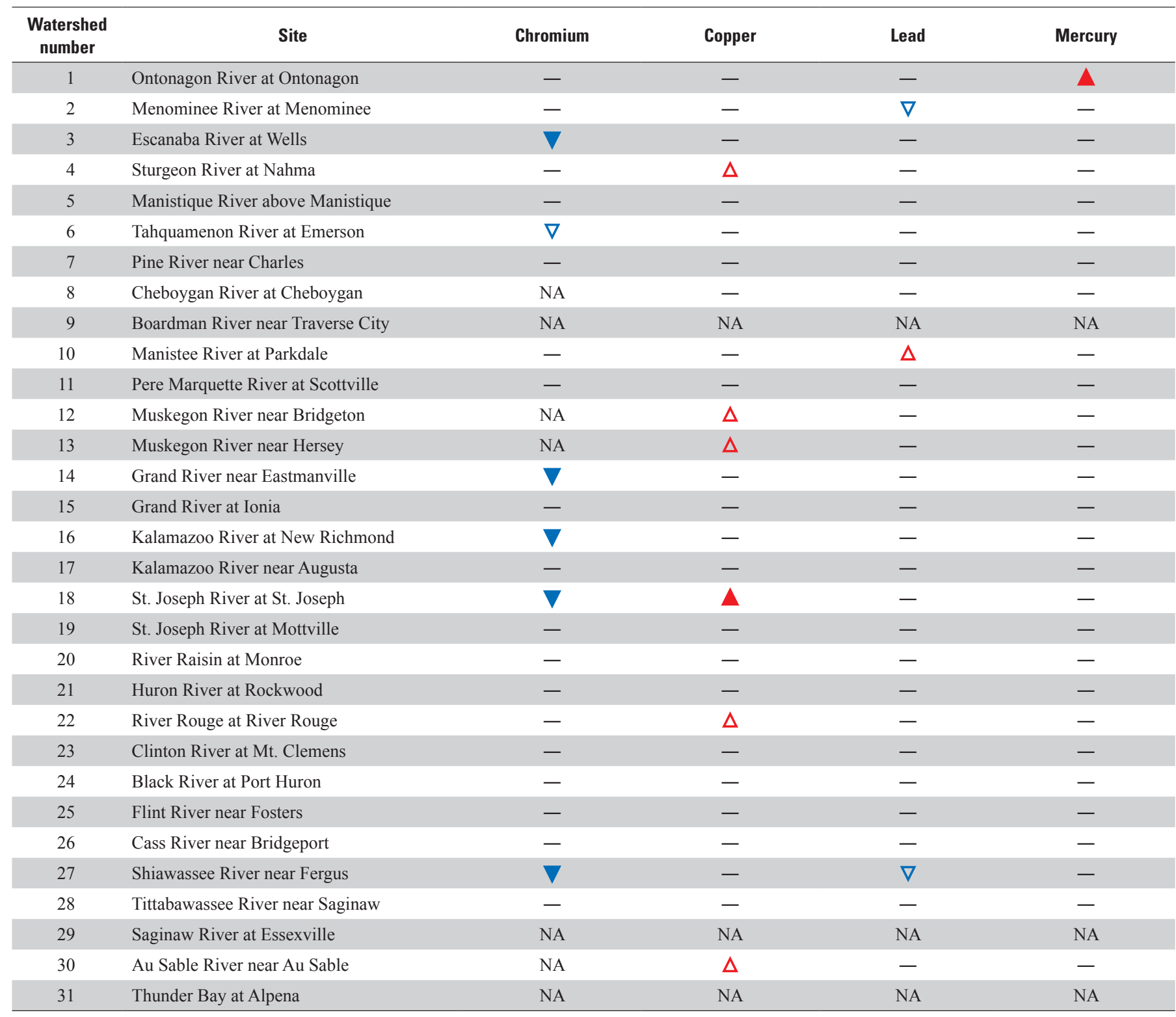

Saginaw Bay (on the eastern side of the state) is heavily influenced by the water quality of several contributing watersheds. These contributing watersheds were watersheds 26-28, represented by the sites on the Flint, Cass, Shiawassee, and Tittabawassee Rivers respectively. Two of the measured watersheds (Shiawassee and Tittabawassee) in this region show a downward trend in turbidity (fig. 15). Decreasing turbidity might suggest that other chemicals associated with sediment transport, which were not sampled as part of this study, may also be decreasing. It should be noted that the area in the eastcentral Lower Peninsula commonly referred to as the thumb area of Michigan (fig. 1) is not well represented in this study. This area has a large agricultural land-use component that may be contributing nutrients to Saginaw Bay and Lake Huron.

Other regional trends were observed in this study. For example, copper concentrations appear to be increasing in the northern Lower Peninsula. Nitrite is increasing in both the Black River and Clinton River Watersheds (fig.17). The Black River has a large agricultural land-use component, and the Clinton River is dominated by urban land-use effects. Both of these watersheds are tributaries to Lake St. Clair and thus influence the water quality of Lake St. Clair. 

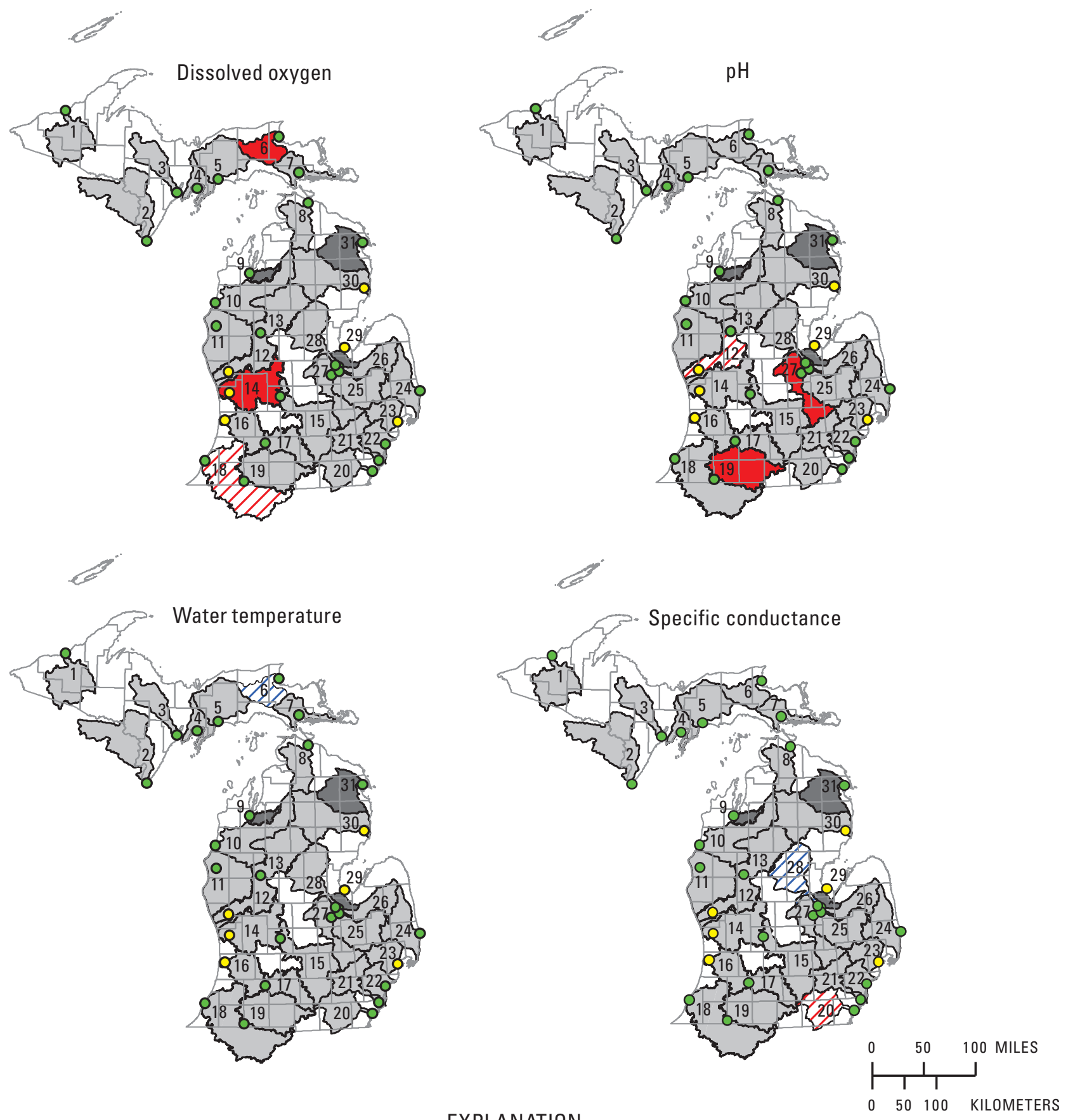

EXPLANATION

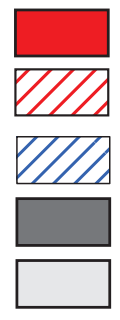

Increasing trend with p-value less than or equal to 0.05

Increasing trend with $\mathrm{p}$-value greater than 0.05 but less than 0.1

Decreasing trend with $p$-value greater than 0.05 but less than 0.1

Insufficient data for trend analysis

No trend

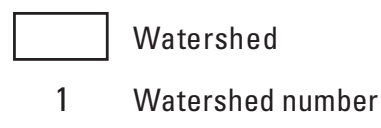

Site location

- Integrator

○ Intensive

Basemap: State and County boundaries from the Michigan Geographic Framework, 2003.

Watershed boundaries from 1:250,000 Hydrologic Unit Codes (U.S. Geological Society, 1994) and split as necessary using upstream 1:24,000 watershed boundaries (Michigan Department of Environmental Quality, 1998).

Figure 15. Trend results for dissolved oxygen, $\mathrm{pH}$, water temperature, and specific conductance by Michigan watershed. 

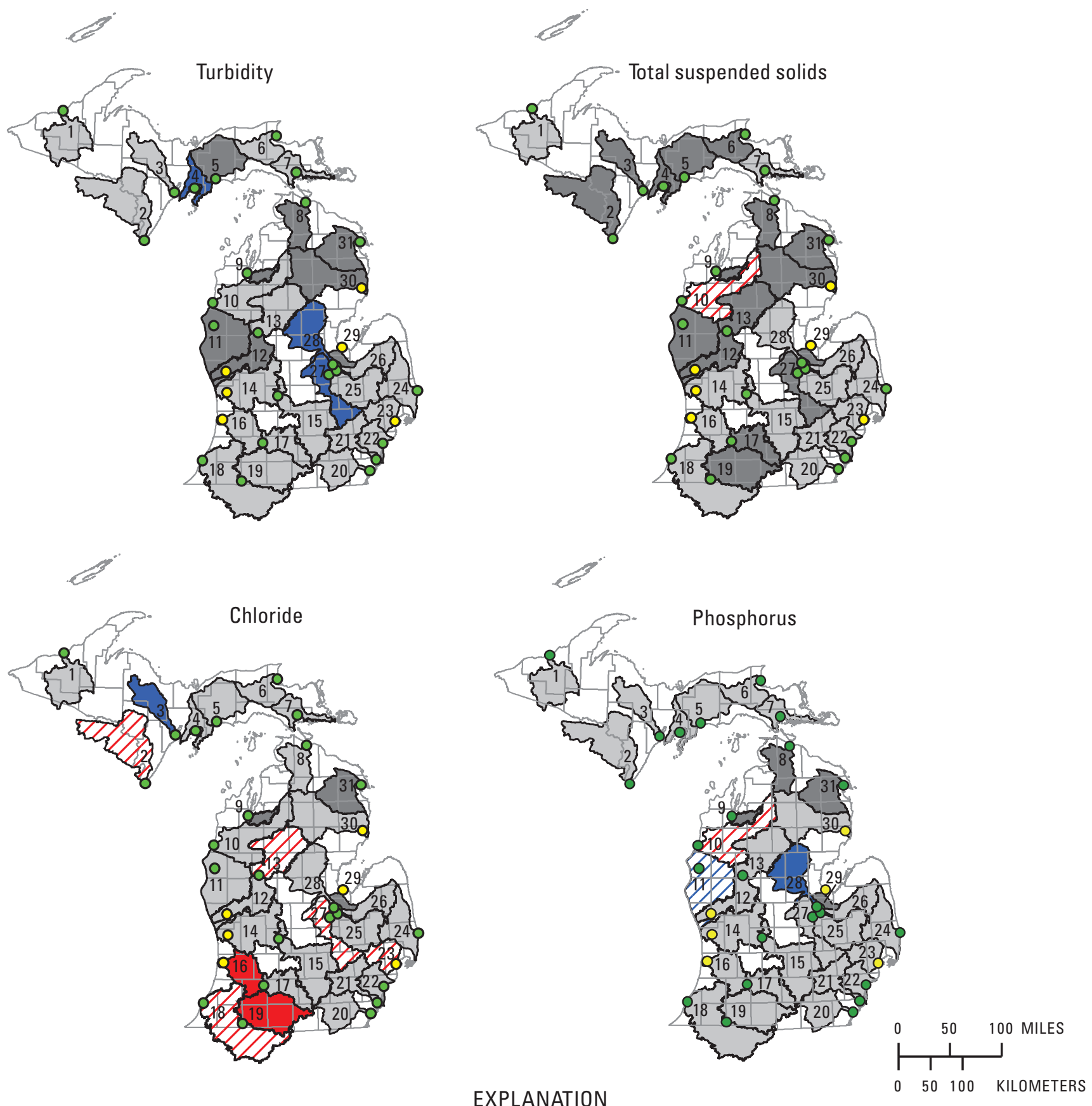

EXPLANATION

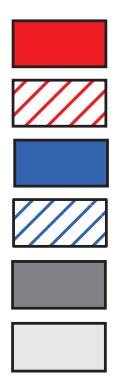

Increasing trend with $\mathrm{p}$-value less than or equal to 0.05 Increasing trend with $p$-value greater than 0.05 but less than 0.1 Decreasing trend with $p$-value less than or equal to 0.05 Decreasing trend with $p$-value greater than 0.05 but less than 0.1 Insufficient data for trend analysis

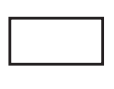

Watershed

1 Watershed number Site location
- Integrator
○ Intensive

Basemap: State and County boundaries from the Michigan Geographic Framework, 2003.

Watershed boundaries from 1:250,000 Hydrologic Unit Codes (U.S. Geological Society, 1994) and split as necessary using upstream 1:24,000 watershed boundaries (Michigan Department of Environmental Quality, 1998).

Figure 16. Trend results for turbidity, total suspended solids, chloride, and phosphorus by Michigan watershed. 

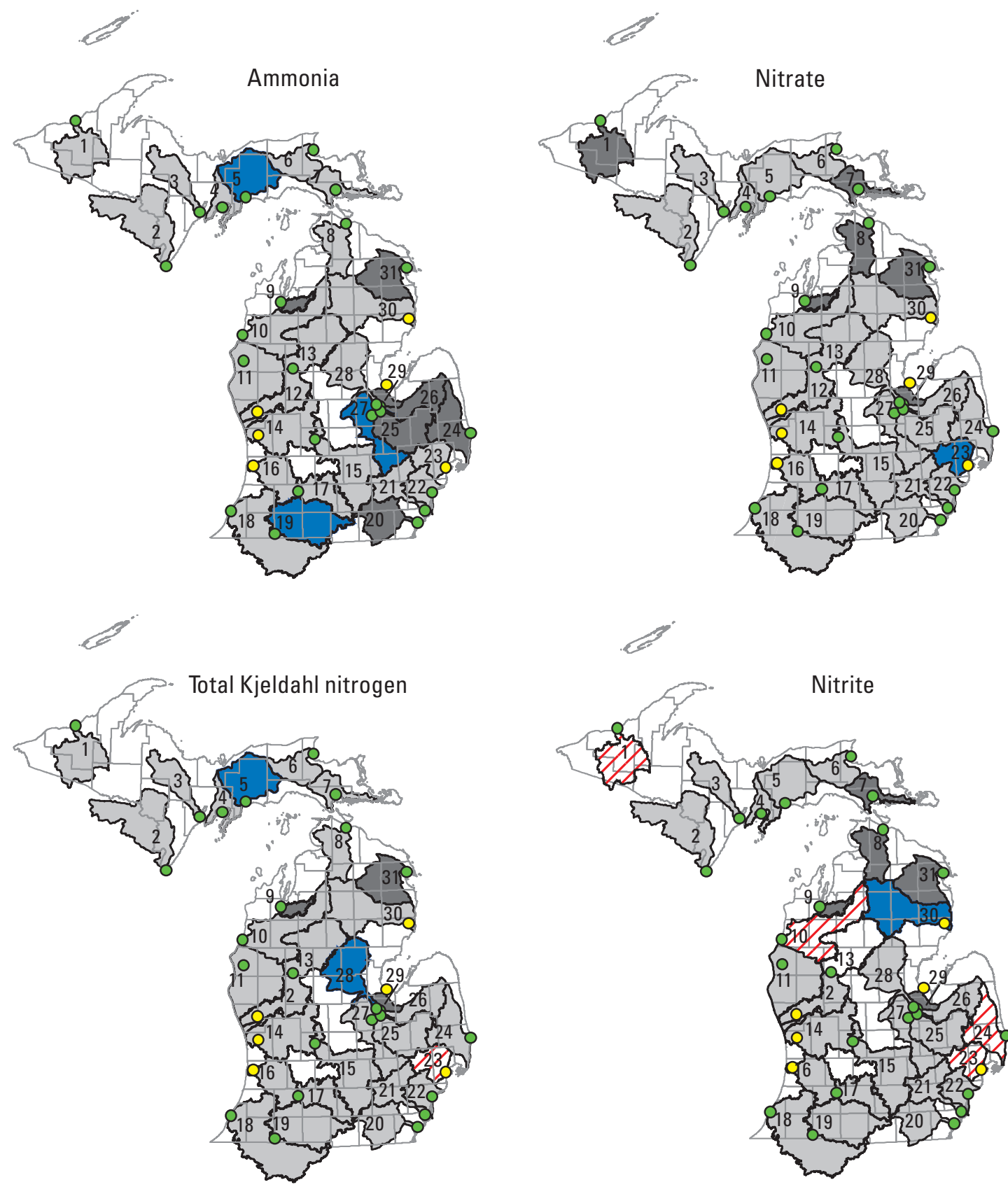

EXPLANATION



77 Increasing trend with $p$-value greater than 0.05 but less than 0.1

Decreasing trend with $\mathrm{p}$-value less than or equal to 0.05

$\square$ Insufficient data for trend analysis

No trend

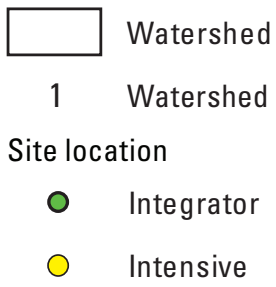

Basemap: State and County boundaries from the Michigan Geographic Framework, 2003.

Watershed boundaries from 1:250,000 Hydrologic Unit Codes (U.S. Geological Society, 1994) and split as necessary using upstream 1:24,000 watershed boundaries (Michigan Department of Environmental Quality, 1998).

Figure 17. Trend results for ammonia, nitrate, total Kjeldahl nitrogen, and nitrite by Michigan watershed. 

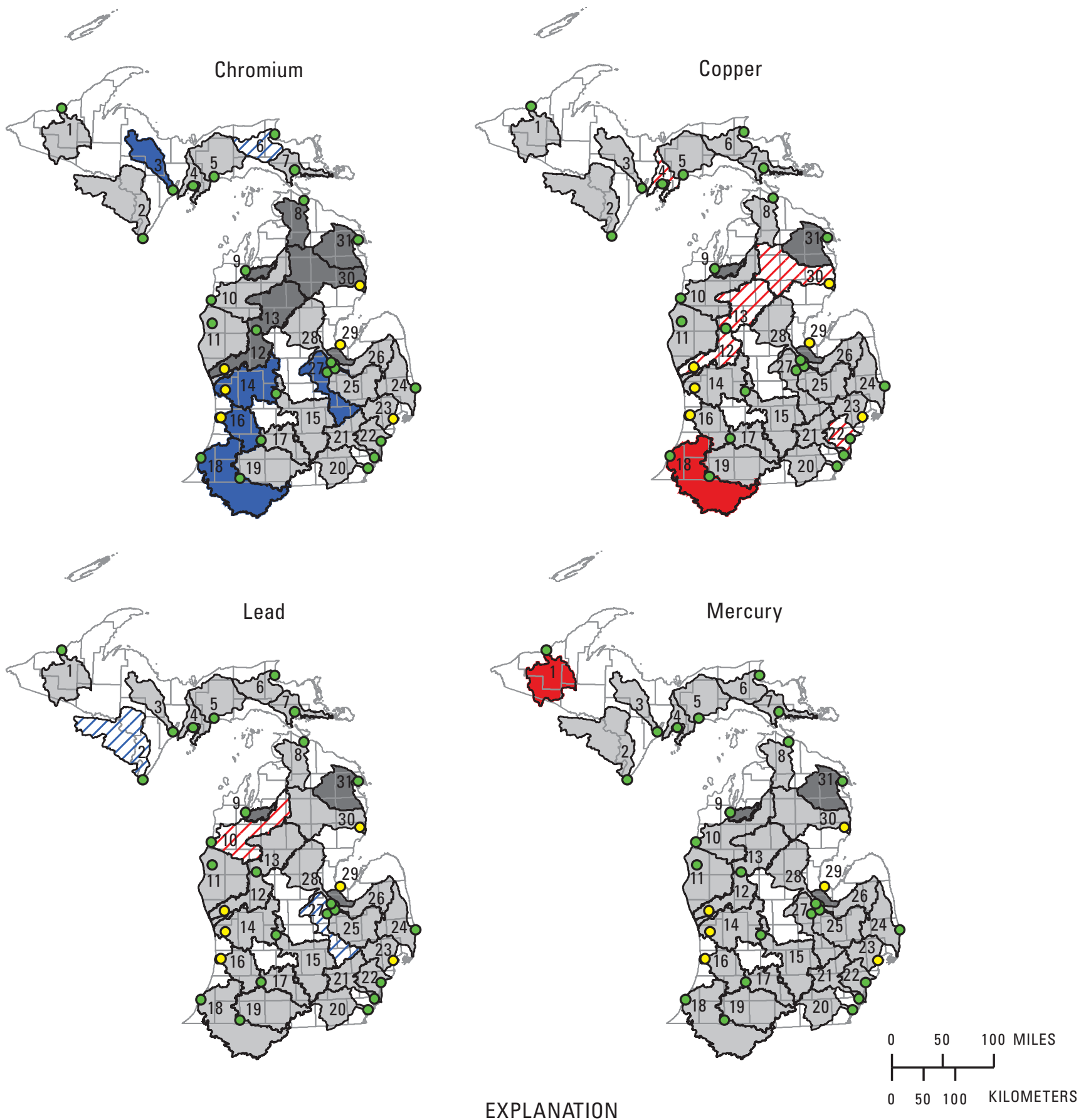

EXPLANATION

Increasing trend with $\mathrm{p}$-value less than or equal to 0.05

71 Increasing trend with $\mathrm{p}$-value greater than 0.05 but less than 0.1

Decreasing trend with $p$-value less than or equal to 0.05

17 Decreasing trend with $\mathrm{p}$-value greater than 0.05 but less than 0.1

Insufficient data for trend analysis

$0 \quad 50 \quad 100 \quad$ KILOMETERS

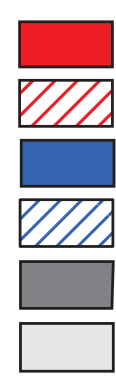

No trend

Basemap: State and County boundaries from the Michigan Geographic Framework, 2003.

Watershed boundaries from 1:250,000 Hydrologic Unit Codes (U.S. Geological Society, 1994) and split as necessary using upstream 1:24,000 watershed boundaries (Michigan Department of Environmental Quality, 1998).

Figure 18. Trend results for chromium, copper, lead, and mercury by Michigan watershed. 


\section{Summary and Conclusions}

In 1998, the Michigan Department of Environmental Quality (MDEQ) and the U.S. Geological Survey (USGS) began a long-term monitoring program to evaluate the water quality of most watersheds in Michigan. Major goals of the program were to identify streams exceeding or not meeting water-quality standards and to assess whether measured values of physical properties and concentrations of chemical constituents reflecting water quality in these streams were increasing or decreasing over time. As part of this program, water-quality data collected over 1998-2005 were analyzed to identify potential trends and to provide an understanding of changes in water quality. In all, 16 properties and constituents were analyzed for 28 sites across Michigan.

The uncensored Seasonal Kendall test within the ESTREND program was used for analysis of the various water-quality data. Variability in measured properties and constituent concentrations associated with temporal and streamflow-related factors are accounted for in ESTREND. In addition, missing record, censored data, and a non-normal distribution of data can be accommodated by use of this nonparametric trend-testing technique. For all properties and constituents tested at the selected sites, data sets spanned a minimum of 5 years of record and contained less than 5 percent censored values, and at least 30 percent of the values were within the beginning one-fifth and ending one-fifth of the selected period. Upward trends indicated an increase in a measured property or constituent concentration over time, whereas downward trends indicated a decrease.

The most prevalent trend detected throughout the state was for chloride concentration; trends were detected at 8 of the 28 sites, with upward trends at 7 sites and a downward trend at 1 site. Among the trace metals examined in this study, chromium showed a prevalence of downward trends, indicating an overall improvement in water quality with regards to chromium. This improvement may be the result of changes in industrial practices over time. In contrast, the trace metal copper had an upward trend at six sites. Among the nutrients examined in this study, trends in nitrite were the most commonly detected. Upward trends for nitrite were detected at five sites on the Manistee, Clinton, upper Muskegon, Black, and Ontonagon Rivers.

Although trends in constituent concentrations were not detected at all sites, the data collected as part of this project were still valuable in evaluating the quality of streams in the State of Michigan. This report identified sites where no statistically significant trends were detected but where constituent concentrations did not meet water-quality criteria. At several sites, nitrogen and phosphorus were measured at concentrations much higher than USEPA recommendations for nutrients in water. High nitrogen concentrations were measured at several sites in watersheds with agricultural inputs. Phosphorus also was detected at high concentrations in several watersheds with substantial areas of urban and agricultural land use.
Trend analysis for water-quality data collected during 1998-2005 provided an overview of how water quality may be changing over time. In addition, this analysis established a baseline against which to evaluate future changes in water quality. Many factors may be affecting changes in water quality, and trend analyses served to assist in identifying some of these factors. Further site-specific investigations would be needed to better address how policy, land-use, climatic, wastewater, and agricultural issues or practices are affecting the water quality in the various watersheds.

\section{References Cited}

Blumer, S.P., 1993, Michigan stream water quality, in U.S. Geological Survey, National Water Summary 1990-91Stream water quality: U.S. Geological Survey Water-Supply Paper 2400, p. 325-334.

Extension Toxicology Network, 1996, Copper sulfate: accessed July 1, 2008, at http://extoxnet.orst.edu/pips/ coppersu.htm

Gray, J.R., and Glysson, G.D., 2003, Proceedings of the federal interagency workshop on turbidity and other sediment surrogates, April 30-May2, 2002, Reno, Nevada: U.S. Geological Survey Circular 1250, 56 p., accessed September 11, 2008, at http://pubs.usgs.gov/circ/2003/ circ1250/pdf/circ1250.book_web.pdf

Helsel, D.R., and Hirsch, R.M., 2002, Statistical methods in water resources: U.S. Geological Survey Techniques of Water-Resources Investigations, book 4, chap. A3, 524 p.

Hirsch, R.M., Alexander, R.B., and Smith, R.A., 1991, Selection of methods for the detection and estimation of trends in water quality: Water Resources Research, v. 29, no. 5, p. 803-813.

Hirsch, R.M., Slack, J.R., and Smith, R.A, 1982, Techniques of trend analysis for monthly water quality data: Water Resources Research, v. 18, no. 1, p. 107-121.

Michigan Department of Environmental Quality, 2001, Michigan water chemistry trend monitoring, 1998-1999 report: MI/DEQ/SWQ-02/025, accessed June 20, 2008, at $h t t p: / / w w w . d e q . s t a t e . m i . u s / d o c u m e n t s / d e q-s w q-$ gleas9899trendreport.pdf

Michigan Department of Environmental Quality, 2002, Michigan water chemistry trend monitoring, 2000 report: MI/DEQ/SWQ-02/092, accessed June 20, 2008, at http://www.deq.state.mi.us/documents/deq-swq-gleas2000trendreport.pdf 
Michigan Department of Environmental Quality, 2003, Michigan water chemistry monitoring, 2001 report: MI/DEQ/ SWQ-03/085, accessed June 20, 2008, at http://www.deq. state.mi.us/documents/deq-swq-gleas-2001trendreport.pdf

Michigan Department of Environmental Quality, 2004, Michigan water chemistry monitoring, Great Lakes tributaries, 2002 report: MI/DEQ/WB-04/049, accessed June 20, 2008, at http://www.deq.state.mi.us/documents/ deq-wb-swas-2002trendreport.pdf

Michigan Department of Environmental Quality, 2005, Michigan water chemistry monitoring, Great Lakes tributaries, 2003 report: MI/DEQ/WB-05/058, accessed June 20,2008, at http://www.deq.state.mi.us/documents/ deq-wb-swas-03tribreport.pdf

Michigan Department of Environmental Quality, 2006a, Michigan water chemistry monitoring, Great Lakes tributaries, 2004 report: MI/DEQ/WB-06/045, accessed June 20, 2008, at http://www.deq.state.mi.us/documents/ deq-wb-swas-04tribreport.pdf

Michigan Department of Environmental Quality, 2006b, Part 4 water quality standards: accessed October 2, 2007, at http://www.michigan.gov/documents/deq/wb-swas-rulespart4_254149_7.pdf

Michigan Department of Environmental Quality, 2007, Rule 57 water quality values: accessed October 2, 2007, at http://www.michigan.gov/deq/0,1607,7-1353313_3686_3728-11383--,00.html

Michigan Department of Environmental Quality, 2008a, Michigan water chemistry monitoring, Great Lakes tributaries, 1998-2005 report: MI/DEQ/WB-08/014, accessed June 20, 2008, at http://www.michigan.gov/ documents/deq/wb-swas-9805tribreport_222804_7.pdf

Michigan Department of Environmental Quality, 2008b, Water chemistry: accessed June 20, 2008, at http://www.michigan. gov/deq/0,1607,7-135-3313_3686_3728-32361--,00.html

National Oceanic and Atmospheric Administration, 1999, Climatological data annual summary - Michigan 1998: v. 113 , no. 13,27 p.

National Oceanic and Atmospheric Administration, 2000, Climatological data annual summary - Michigan 1999: v. 114, no. 13,27 p.

National Oceanic and Atmospheric Administration, 2001, Climatological data annual summary - Michigan 2000: v. 115 , no. 13,27 p.

National Oceanic and Atmospheric Administration, 2002, Climatological data annual summary - Michigan 2001: v. 116, no. 13,29 p.
National Oceanic and Atmospheric Administration, 2003, Climatological data annual summary - Michigan 2002: v. 117 , no. 13,33 p.

National Oceanic and Atmospheric Administration, 2004, Climatological data annual summary - Michigan 2003: v. 118 , no. 13,35 p.

National Oceanic and Atmospheric Administration, 2005, Climatological data annual summary - Michigan 2004: v. 119, no. 13,35 p.

National Oceanic and Atmospheric Administration, 2006, Climatological data annual summary - Michigan 2005: v. 120 , no. 13,43 p.

New Jersey Department of Environmental Protection, 1998, New Jersey's modernized ambient chemical monitoring network: Trenton, N.J., Division of Watershed Management, $12 \mathrm{p}$.

Schertz, T.L., Alexander, R.B., and Ohe, D.J., 1991, The computer program Estimate Trend (ESTREND), a system of detection of trends in water quality data: U.S. Geological Survey Water-Resources Investigation Report 91-4040, 63 p.

Syed, A.U., and Fogarty, L.R., 2005, Trends in surface-water quality at selected National Stream Quality Accounting Network (NASQAN) Stations, in Michigan: U.S. Geological Survey Scientific Investigations Report 2005-5158, 38 p., at http://pubs.usgs.gov/sir/2005/5158

Team for Evaluating the Wisconsin Water-Monitoring Network, 1998, An integrated water-monitoring network for Wisconsin: Madison, Wis., University of Wisconsin Water Resources Center, WRC SR 98-01, 62 p. http://wi.water. usgs.gov/pubs/FS-048-98/FS-048-98.pdf

U.S. Environmental Protection Agency, 1988, Ambient water quality criteria for chloride -1988: Washington, D.C., EPA 440/5-88-001, accessed March 30, 2009, at http:// www.epa.gov/waterscience/criteria/library/ambientwqc/ chloride1988.pdf

U.S. Environmental Protection Agency, 2000, Ambient water quality criteria recommendations: information supporting the development of state and tribal nutrient criteria for rivers and streams in nutrient Ecoregion III; EPA 822-B-00-016, 20 p., accessed March 30, 2009, at http://www.epa.gov/waterscience/criteria/library/index.html

U.S. Environmental Protection Agency, 2002, Summary table for the nutrient criteria documents: accessed March 30, 2009, at http://www.epa.gov/waterscience/criteria/nutrient/ ecoregions/files/sumtable.pdf

U.S. Environmental Protection Agency, 2007, 2007 Updated aquatic life copper criteria: accessed July 1, 2008, at http:// www.epa.gov/waterscience/criteria/copper/2007/index.htm 
U.S. Geological Survey, 1994, 1:250,000-scale Hydrologic Units of the United States: available online at http://water. usgs.gov/GIS/metadata/usgswrd/XML/huc250k.xml

Wilde, F.D., and Radtke, D.B., August 2005, General information and guidelines (version 1.2):

U.S. Geological Survey Techniques of Water-Resources Investigations, book 9, chap. A6, section 6.0, accessed April 25, 2008, at http://water.usgs.gov/owq/FieldManual/ Chapter6/Ch6_contents.html 
Appendix 1. Summary of data collected at select Michigan Water-Chemistry Monitoring Progam stream sites, 1999-2005.

$\left[\mathrm{mg} / \mathrm{L}\right.$, milligrams per liter; $\mu \mathrm{g} / \mathrm{L}$, micrograms per liter, ng/L, nanograms per liter, $\mu \mathrm{S} / \mathrm{cm}$, microsiemens per centimeter; ${ }^{\circ} \mathrm{C}$, degrees Celsius; USGS, U.S. Geological Survey; N, Nitrogen; P, Phosphorus; NTU, Nephelometric Turbidity Unit; -- , trend not tested]

\begin{tabular}{|c|c|c|c|c|c|c|c|c|c|c|c|c|}
\hline $\begin{array}{c}\text { Watershed } \\
\text { number }\end{array}$ & Site & $\begin{array}{l}\text { USGS } \\
\text { station } \\
\text { number }\end{array}$ & Constituent & $\begin{array}{c}\text { Number } \\
\text { of } \\
\text { samples } \\
\text { collected }\end{array}$ & $\begin{array}{l}\text { Number of } \\
\text { censored } \\
\text { results }\end{array}$ & $\begin{array}{c}\text { Minimum } \\
\text { concen- } \\
\text { tration }\end{array}$ & $\begin{array}{c}\text { Median } \\
\text { concen- } \\
\text { tration }\end{array}$ & $\begin{array}{c}\text { Maximum } \\
\text { concen- } \\
\text { tration }\end{array}$ & $\begin{array}{c}\text { Years } \\
\text { of data } \\
\text { used }\end{array}$ & $\begin{array}{c}\text { Seasons } \\
\text { used }\end{array}$ & $\begin{array}{c}\text { Trend } \\
\text { as a } \\
\text { percent- } \\
\text { age }\end{array}$ & $\begin{array}{c}\text { P-value } \\
\text { of } \\
\text { trend }\end{array}$ \\
\hline 1 & Ontonagon River at Ontonagon & 04040018 & $\begin{array}{l}\text { Ammonia } \\
(\mathrm{mg} / \mathrm{L} \text { as } \mathrm{N})\end{array}$ & 23 & 0 & 0.003 & 0.008 & 0.024 & 6 & 2 & 0.80 & 1.00 \\
\hline 1 & Ontonagon River at Ontonagon & 04040018 & Chloride (mg/L) & 23 & 0 & 2 & 3 & 7 & 6 & 2 & 0.00 & 0.19 \\
\hline 1 & Ontonagon River at Ontonagon & 04040018 & Chromium $(\mu \mathrm{g} / \mathrm{L})$ & 23 & 0 & 0.331 & 0.899 & 3.54 & 6 & 2 & -0.66 & 1.00 \\
\hline 1 & Ontonagon River at Ontonagon & 04040018 & Copper $(\mu \mathrm{g} / \mathrm{L})$ & 23 & 0 & 1.12 & 3.29 & 7.17 & 6 & 2 & 7.68 & 0.15 \\
\hline 1 & Ontonagon River at Ontonagon & 04040018 & Dissolved oxygen (mg/L) & 23 & 0 & 6.5 & 8.6 & 13 & 6 & 2 & -0.93 & 0.79 \\
\hline 1 & Ontonagon River at Ontonagon & 04040018 & Lead $(\mu \mathrm{g} / \mathrm{L})$ & 23 & 0 & 0.0605 & 0.26 & 1.16 & 6 & 2 & 6.97 & 0.15 \\
\hline 1 & Ontonagon River at Ontonagon & 04040018 & Mercury (ng/L) & 23 & 1 & 0.3 & 2.18 & 8.35 & 6 & 2 & 9.63 & 0.04 \\
\hline 1 & Ontonagon River at Ontonagon & 04040018 & Nitrate (mg/L as N) & 20 & 4 & 0.001 & 0.023 & 0.21 & -- & -- & -- & -- \\
\hline 1 & Ontonagon River at Ontonagon & 04040018 & Nitrite (mg/L as N) & 23 & 0 & 0.001 & 0.006 & 0.019 & 6 & 2 & 24.83 & 0.06 \\
\hline 1 & Ontonagon River at Ontonagon & 04040018 & $\mathrm{pH}$ & 23 & 0 & 7.1 & 7.66 & 8 & 6 & 2 & -0.49 & 0.42 \\
\hline 1 & Ontonagon River at Ontonagon & 04040018 & Total phosphorus (mg/L as $\mathrm{P}$ ) & 23 & 0 & 0.015 & 0.037 & 0.167 & 6 & 2 & -1.45 & 1.00 \\
\hline 1 & Ontonagon River at Ontonagon & 04040018 & Specific conductance $(\mu \mathrm{S} / \mathrm{cm})$ & 23 & 0 & 59.6 & 144 & 179 & 6 & 2 & -0.44 & 1.00 \\
\hline 1 & Ontonagon River at Ontonagon & 04040018 & $\begin{array}{l}\text { Total Kjehldahl nitrogen } \\
(\mathrm{mg} / \mathrm{L} \text { as } \mathrm{N})\end{array}$ & 23 & 0 & 0.22 & 0.4 & 0.73 & 6 & 2 & 3.72 & 1.00 \\
\hline 1 & Ontonagon River at Ontonagon & 04040018 & Total suspended solids (mg/L) & 23 & 0 & 4 & 13 & 130 & 6 & 2 & 3.08 & 1.00 \\
\hline 1 & Ontonagon River at Ontonagon & 04040018 & Turbidity (NTU) & 23 & 0 & 7.5 & 23 & 130 & 6 & 2 & 2.32 & 0.47 \\
\hline 1 & Ontonagon River at Ontonagon & 04040018 & Water temperature $\left({ }^{\circ} \mathrm{C}\right)$ & 23 & 0 & 1.7 & 16.4 & 27.6 & 6 & 2 & -7.00 & 0.48 \\
\hline 2 & Menominee River at Menominee & 04067648 & $\begin{array}{l}\text { Ammonia } \\
\quad(\mathrm{mg} / \mathrm{L} \text { as } \mathrm{N})\end{array}$ & 31 & 0 & 0.004 & 0.016 & 0.047 & 6 & 3 & -1.07 & 0.48 \\
\hline 2 & Menominee River at Menominee & 04067648 & Chloride (mg/L) & 31 & 0 & 3 & 6 & 9 & 6 & 3 & 3.94 & 0.09 \\
\hline 2 & Menominee River at Menominee & 04067648 & Chromium $(\mu \mathrm{g} / \mathrm{L})$ & 31 & 0 & 0.049 & 0.257 & 0.976 & 6 & 3 & -5.91 & 0.48 \\
\hline 2 & Menominee River at Menominee & 04067648 & Copper $(\mu \mathrm{g} / \mathrm{L})$ & 31 & 0 & 0.489 & 0.884 & 1.64 & 6 & 3 & 0.91 & 1.00 \\
\hline 2 & Menominee River at Menominee & 04067648 & Dissolved oxygen (mg/L) & 31 & 0 & 5.6 & 9.3 & 12.9 & 6 & 3 & -0.07 & 1.00 \\
\hline 2 & Menominee River at Menominee & 04067648 & Lead $(\mu \mathrm{g} / \mathrm{L})$ & 31 & 0 & 0.0506 & 0.139 & 0.851 & 6 & 3 & -5.64 & 0.07 \\
\hline 2 & Menominee River at Menominee & 04067648 & Mercury (ng/L) & 30 & 1 & 0.45 & 2.755 & 12.1 & 6 & 2 & -0.34 & 1.00 \\
\hline 2 & Menominee River at Menominee & 04067648 & Nitrate (mg/L as N) & 29 & 2 & 0.002 & 0.071 & 0.27 & 6 & 3 & -16.76 & 0.27 \\
\hline 2 & Menominee River at Menominee & 04067648 & Nitrite (mg/L as N) & 31 & 0 & 0.001 & 0.004 & 0.007 & 6 & 3 & 0.93 & 1.00 \\
\hline 2 & Menominee River at Menominee & 04067648 & $\mathrm{pH}$ & 31 & 0 & 7.2 & 7.8 & 8.3 & 6 & 3 & 0.14 & 1.00 \\
\hline 2 & Menominee River at Menominee & 04067648 & Total phosphorus (mg/L as $\mathrm{P}$ ) & 31 & 0 & 0.015 & 0.033 & 0.1 & 6 & 3 & -1.80 & 0.79 \\
\hline 2 & Menominee River at Menominee & 04067648 & Specific conductance $(\mu \mathrm{S} / \mathrm{cm})$ & 31 & 0 & 102 & 243 & 308 & 6 & 3 & 3.32 & 0.33 \\
\hline
\end{tabular}


Appendix 1. Summary of data collected at select Michigan Water-Chemistry Monitoring Progam stream sites, 1999-2005.—Continued

$\left[\mathrm{mg} / \mathrm{L}\right.$, milligrams per liter; $\mu \mathrm{g} / \mathrm{L}$, micrograms per liter, ng/L, nanograms per liter, $\mu \mathrm{S} / \mathrm{cm}$, microsiemens per centimeter; ${ }^{\circ} \mathrm{C}$, degrees Celsius; USGS, U.S. Geological Survey; N, Nitrogen; P, Phosphorus; NTU, Nephelometric Turbidity Unit; -- , trend not tested]

\begin{tabular}{|c|c|c|c|c|c|c|c|c|c|c|c|c|}
\hline $\begin{array}{c}\text { Watershed } \\
\text { number }\end{array}$ & Site & $\begin{array}{l}\text { USGS } \\
\text { station } \\
\text { number }\end{array}$ & Constituent & $\begin{array}{c}\text { Number } \\
\text { of } \\
\text { samples } \\
\text { collected }\end{array}$ & $\begin{array}{l}\text { Number of } \\
\text { censored } \\
\text { results }\end{array}$ & $\begin{array}{c}\text { Minimum } \\
\text { concen- } \\
\text { tration }\end{array}$ & $\begin{array}{c}\text { Median } \\
\text { concen- } \\
\text { tration }\end{array}$ & $\begin{array}{c}\text { Maximum } \\
\text { concen- } \\
\text { tration }\end{array}$ & $\begin{array}{c}\text { Years } \\
\text { of data } \\
\text { used }\end{array}$ & $\begin{array}{l}\text { Seasons } \\
\text { used }\end{array}$ & $\begin{array}{l}\text { Trend } \\
\text { as a } \\
\text { percent- } \\
\text { age }\end{array}$ & $\begin{array}{c}\text { P-value } \\
\text { of } \\
\text { trend }\end{array}$ \\
\hline 2 & Menominee River at Menominee & 04067648 & $\begin{array}{l}\text { Total Kjehldahl nitrogen } \\
(\mathrm{mg} / \mathrm{L} \text { as } \mathrm{N})\end{array}$ & 31 & 0 & 0.31 & 0.48 & 0.84 & 6 & 3 & -1.84 & 0.79 \\
\hline 2 & Menominee River at Menominee & 04067648 & Total suspended solids (mg/L) & 31 & 8 & 4 & 4 & 41 & -- & -- & -- & -- \\
\hline 2 & Menominee River at Menominee & 04067648 & Turbidity (NTU) & 31 & 2 & 1 & 3 & 15 & 6 & 3 & -7.89 & 0.27 \\
\hline 2 & Menominee River at Menominee & 04067648 & Water temperature $\left({ }^{\circ} \mathrm{C}\right)$ & 31 & 0 & 4 & 17.5 & 26 & 6 & 3 & -2.55 & 0.64 \\
\hline 3 & Escanaba River at Wells & 040590345 & $\begin{array}{l}\text { Ammonia } \\
\quad(\mathrm{mg} / \mathrm{L} \text { as } \mathrm{N})\end{array}$ & 47 & 0 & 0.024 & 0.056 & 0.135 & 7 & 3 & 2.50 & 0.70 \\
\hline 3 & Escanaba River at Wells & 040590345 & Chloride (mg/L) & 47 & 0 & 5 & 18 & 61 & 7 & 3 & -9.35 & 0.04 \\
\hline 3 & Escanaba River at Wells & 040590345 & Chromium $(\mu \mathrm{g} / \mathrm{L})$ & 47 & 0 & 0.129 & 0.604 & 1.29 & 7 & 3 & -17.90 & 0.03 \\
\hline 3 & Escanaba River at Wells & 040590345 & Copper $(\mu \mathrm{g} / \mathrm{L})$ & 47 & 0 & 0.508 & 0.841 & 2.33 & 7 & 3 & -0.50 & 1.00 \\
\hline 3 & Escanaba River at Wells & 040590345 & Dissolved oxygen (mg/L) & 45 & 0 & 5.1 & 8.6 & 13.7 & 7 & 3 & -1.10 & 0.76 \\
\hline 3 & Escanaba River at Wells & 040590345 & Lead $(\mu \mathrm{g} / \mathrm{L})$ & 47 & 0 & 0.109 & 0.153 & 0.765 & 7 & 3 & -4.64 & 0.13 \\
\hline 3 & Escanaba River at Wells & 040590345 & Mercury (ng/L) & 47 & 1 & 0.45 & 2.9 & 55.357 & 7 & 3 & -9.32 & 0.57 \\
\hline 3 & Escanaba River at Wells & 040590345 & Nitrate (mg/L as N) & 47 & 0 & 0.067 & 0.118 & 0.42 & 7 & 3 & -1.00 & 0.60 \\
\hline 3 & Escanaba River at Wells & 040590345 & Nitrite $(\mathrm{mg} / \mathrm{L}$ as $\mathrm{N})$ & 47 & 0 & 0.004 & 0.012 & 0.054 & 7 & 3 & 3.73 & 0.31 \\
\hline 3 & Escanaba River at Wells & 040590345 & $\mathrm{pH}$ & 46 & 0 & 6.8 & 7.815 & 8.6 & 7 & 3 & 0.45 & 0.25 \\
\hline 3 & Escanaba River at Wells & 040590345 & Total phosphorus (mg/L as $\mathrm{P}$ ) & 47 & 0 & 0.006 & 0.038 & 0.19 & 7 & 3 & -14.28 & 0.15 \\
\hline 3 & Escanaba River at Wells & 040590345 & Specific conductance $(\mu \mathrm{S} / \mathrm{cm})$ & 46 & 0 & 154 & 351.5 & 714 & 7 & 3 & -0.08 & 1.00 \\
\hline 3 & Escanaba River at Wells & 040590345 & $\begin{array}{l}\text { Total Kjehldahl nitrogen } \\
(\mathrm{mg} / \mathrm{L} \text { as } \mathrm{N})\end{array}$ & 47 & 0 & 0.41 & 0.6 & 1.06 & 7 & 3 & -0.23 & 1.00 \\
\hline 3 & Escanaba River at Wells & 040590345 & Total suspended solids (mg/L) & 47 & 15 & 1 & 4 & 19 & -- & -- & -- & -- \\
\hline 3 & Escanaba River at Wells & 040590345 & Turbidity (NTU) & 34 & 0 & 2.6 & 4.35 & 12 & 6 & 3 & -5.39 & 0.26 \\
\hline 3 & Escanaba River at Wells & 040590345 & Water temperature $\left({ }^{\circ} \mathrm{C}\right)$ & 45 & 0 & 1.1 & 15.6 & 26.7 & 7 & 3 & 1.06 & 1.00 \\
\hline 4 & Sturgeon River at Nahma & 04057521 & $\begin{array}{l}\text { Ammonia } \\
\qquad(\mathrm{mg} / \mathrm{L} \text { as } \mathrm{N})\end{array}$ & 31 & 0 & 0.008 & 0.019 & 0.061 & 6 & 3 & -2.60 & 0.49 \\
\hline 4 & Sturgeon River at Nahma & 04057521 & Chloride (mg/L) & 31 & 0 & 2 & 2 & 3 & 6 & 3 & -1.23 & 0.21 \\
\hline 4 & Sturgeon River at Nahma & 04057521 & Chromium $(\mu \mathrm{g} / \mathrm{L})$ & 31 & 0 & 0.092 & 0.344 & 0.74 & 6 & 3 & -9.31 & 0.13 \\
\hline 4 & Sturgeon River at Nahma & 04057521 & Copper $(\mu \mathrm{g} / \mathrm{L})$ & 31 & 0 & 0.206 & 0.418 & 0.8 & 6 & 3 & 5.36 & 0.10 \\
\hline 4 & Sturgeon River at Nahma & 04057521 & Dissolved oxygen (mg/L) & 31 & 0 & 6.5 & 9.2 & 12.1 & 6 & 3 & -0.81 & 0.63 \\
\hline 4 & Sturgeon River at Nahma & 04057521 & Lead $(\mu \mathrm{g} / \mathrm{L})$ & 31 & 0 & 0.0348 & 0.187 & 0.551 & 6 & 3 & -6.74 & 0.27 \\
\hline 4 & Sturgeon River at Nahma & 04057521 & Mercury (ng/L) & 31 & 0 & 0.69 & 2.56 & 7.45 & 6 & 3 & 4.14 & 0.42 \\
\hline 4 & Sturgeon River at Nahma & 04057521 & Nitrate (mg/L as N) & 31 & 0 & 0.006 & 0.062 & 0.36 & 6 & 3 & -5.24 & 0.43 \\
\hline
\end{tabular}


Appendix 1. Summary of data collected at select Michigan Water-Chemistry Monitoring Progam stream sites, 1999-2005.-Continued $\left[\mathrm{mg} / \mathrm{L}\right.$, milligrams per liter; $\mu \mathrm{g} / \mathrm{L}$, micrograms per liter, ng/L, nanograms per liter, $\mu \mathrm{S} / \mathrm{cm}$, microsiemens per centimeter; ${ }^{\circ} \mathrm{C}$, degrees Celsius; USGS, U.S. Geological Survey; N, Nitrogen; P, Phosphorus; NTU, Nephelometric Turbidity Unit; -- , trend not tested]

\begin{tabular}{|c|c|c|c|c|c|c|c|c|c|c|c|c|}
\hline $\begin{array}{l}\text { Watershed } \\
\text { number }\end{array}$ & Site & $\begin{array}{l}\text { USGS } \\
\text { station } \\
\text { number }\end{array}$ & Constituent & $\begin{array}{c}\text { Number } \\
\text { of } \\
\text { samples } \\
\text { collected }\end{array}$ & $\begin{array}{l}\text { Number of } \\
\text { censored } \\
\text { results }\end{array}$ & $\begin{array}{c}\text { Minimum } \\
\text { concen- } \\
\text { tration }\end{array}$ & $\begin{array}{c}\text { Median } \\
\text { concen- } \\
\text { tration }\end{array}$ & $\begin{array}{c}\text { Maximum } \\
\text { concen- } \\
\text { tration }\end{array}$ & $\begin{array}{c}\text { Years } \\
\text { of data } \\
\text { used }\end{array}$ & $\begin{array}{l}\text { Seasons } \\
\text { used }\end{array}$ & $\begin{array}{l}\text { Trend } \\
\text { as a } \\
\text { percent- } \\
\text { age }\end{array}$ & $\begin{array}{c}\text { P-value } \\
\text { of } \\
\text { trend }\end{array}$ \\
\hline 4 & Sturgeon River at Nahma & 04057521 & Nitrite (mg/L as N) & 31 & 0 & 0.001 & 0.004 & 0.008 & 6 & 3 & 1.43 & 0.36 \\
\hline 4 & Sturgeon River at Nahma & 04057521 & $\mathrm{pH}$ & 31 & 0 & 6.7 & 7.4 & 8 & 6 & 3 & 0.08 & 1.00 \\
\hline 4 & Sturgeon River at Nahma & 04057521 & Total phosphorus (mg/L as $\mathrm{P}$ ) & 31 & 0 & 0.009 & 0.019 & 0.044 & 6 & 3 & -1.88 & 0.50 \\
\hline 4 & Sturgeon River at Nahma & 04057521 & Specific conductance $(\mu \mathrm{S} / \mathrm{cm})$ & 31 & 0 & 74 & 203 & 298 & 6 & 3 & -0.26 & 0.77 \\
\hline 4 & Sturgeon River at Nahma & 04057521 & $\begin{array}{l}\text { Total Kjehldahl nitrogen } \\
(\mathrm{mg} / \mathrm{L} \text { as } \mathrm{N})\end{array}$ & 31 & 0 & 0.26 & 0.53 & 0.88 & 6 & 3 & -2.97 & 0.21 \\
\hline 4 & Sturgeon River at Nahma & 04057521 & Total suspended solids (mg/L) & 31 & 11 & 3 & 4 & 58 & -- & -- & -- & -- \\
\hline 4 & Sturgeon River at Nahma & 04057521 & Turbidity (NTU) & 31 & 0 & 1.9 & 4.4 & 16 & 6 & 3 & -4.60 & 0.05 \\
\hline 4 & Sturgeon River at Nahma & 04057521 & Water temperature $\left({ }^{\circ} \mathrm{C}\right)$ & 31 & 0 & 2.1 & 13.9 & 26 & 6 & 3 & 3.28 & 0.57 \\
\hline 5 & Manistique River above Manistique & 04057004 & $\begin{array}{l}\text { Ammonia } \\
\quad(\mathrm{mg} / \mathrm{L} \text { as } \mathrm{N})\end{array}$ & 44 & 0 & 0.008 & 0.017 & 0.048 & 7 & 3 & -8.86 & 0.05 \\
\hline 5 & Manistique River above Manistique & 04057004 & Chloride (mg/L) & 44 & 0 & 2 & 2 & 3 & 7 & 3 & 0.00 & 0.21 \\
\hline 5 & Manistique River above Manistique & 04057004 & Chromium $(\mu \mathrm{g} / \mathrm{L})$ & 44 & 0 & 0.095 & 0.3845 & 0.79 & 7 & 3 & -3.59 & 0.67 \\
\hline 5 & Manistique River above Manistique & 04057004 & Copper $(\mu \mathrm{g} / \mathrm{L})$ & 44 & 0 & 0.056 & 0.371 & 0.59 & 7 & 3 & 3.15 & 0.26 \\
\hline 5 & Manistique River above Manistique & 04057004 & Dissolved oxygen (mg/L) & 44 & 0 & 7.2 & 9.025 & 12 & 7 & 3 & -0.14 & 0.92 \\
\hline 5 & Manistique River above Manistique & 04057004 & Lead $(\mu \mathrm{g} / \mathrm{L})$ & 44 & 0 & 0.064 & 0.1655 & 0.407 & 7 & 3 & 0.23 & 1.00 \\
\hline 5 & Manistique River above Manistique & 04057004 & Mercury (ng/L) & 44 & 0 & 0.78 & 2.4205 & 6.068 & 7 & 3 & -4.26 & 0.40 \\
\hline 5 & Manistique River above Manistique & 04057004 & Nitrate $(\mathrm{mg} / \mathrm{L}$ as $\mathrm{N})$ & 44 & 0 & 0.027 & 0.0535 & 0.3 & 7 & 3 & -6.62 & 0.28 \\
\hline 5 & Manistique River above Manistique & 04057004 & Nitrite $(\mathrm{mg} / \mathrm{L}$ as $\mathrm{N})$ & 44 & 1 & 0.002 & 0.003 & 0.007 & 7 & 3 & 1.56 & 0.65 \\
\hline 5 & Manistique River above Manistique & 04057004 & $\mathrm{pH}$ & 44 & 0 & 6.69 & 7.5 & 8.1 & 7 & 3 & 0.17 & 0.42 \\
\hline 5 & Manistique River above Manistique & 04057004 & Total phosphorus (mg/L as $\mathrm{P}$ ) & 44 & 0 & 0.01 & 0.018 & 0.043 & 7 & 3 & -7.31 & 0.43 \\
\hline 5 & Manistique River above Manistique & 04057004 & Specific conductance $(\mu \mathrm{S} / \mathrm{cm})$ & 44 & 0 & 66 & 179 & 222 & 7 & 3 & 0.27 & 0.46 \\
\hline 5 & Manistique River above Manistique & 04057004 & $\begin{array}{l}\text { Total Kjehldahl nitrogen } \\
(\mathrm{mg} / \mathrm{L} \text { as } \mathrm{N})\end{array}$ & 44 & 0 & 0.28 & 0.45 & 0.7 & 7 & 3 & -2.88 & 0.05 \\
\hline 5 & Manistique River above Manistique & 04057004 & Total suspended solids (mg/L) & 44 & 16 & 3 & 5 & 41 & -- & -- & -- & -- \\
\hline 5 & Manistique River above Manistique & 04057004 & Turbidity (NTU) & 31 & 0 & 2.8 & 5.1 & 12 & -- & -- & -- & -- \\
\hline 5 & Manistique River above Manistique & 04057004 & Water temperature $\left({ }^{\circ} \mathrm{C}\right)$ & 44 & 0 & 2 & 15.25 & 23.7 & 7 & 3 & -0.12 & 1.00 \\
\hline 6 & Tahquamenon River at Emerson & 04045510 & Ammonia (mg/L as $\mathrm{N})$ & 44 & 0 & 0.005 & 0.015 & 0.044 & 7 & 3 & -7.46 & 0.39 \\
\hline 6 & Tahquamenon River at Emerson & 04045510 & Chloride (mg/L) & 44 & 0 & 2 & 2 & 4 & 7 & 3 & -0.13 & 0.72 \\
\hline 6 & Tahquamenon River at Emerson & 04045510 & Chromium $(\mu \mathrm{g} / \mathrm{L})$ & 43 & 0 & 0.077 & 0.38 & 0.653 & 7 & 3 & -11.22 & 0.09 \\
\hline 6 & Tahquamenon River at Emerson & 04045510 & Copper $(\mu \mathrm{g} / \mathrm{L})$ & 44 & 0 & 0.17 & 0.3875 & 0.95 & 7 & 3 & 3.91 & 0.30 \\
\hline 6 & Tahquamenon River at Emerson & 04045510 & Dissolved oxygen $(\mathrm{mg} / \mathrm{L})$ & 43 & 0 & 6.8 & 8.9 & 14.5 & 7 & 3 & 2.73 & 0.05 \\
\hline
\end{tabular}


Appendix 1. Summary of data collected at select Michigan Water-Chemistry Monitoring Progam stream sites, 1999-2005.—Continued

$\left[\mathrm{mg} / \mathrm{L}\right.$, milligrams per liter; $\mu \mathrm{g} / \mathrm{L}$, micrograms per liter, ng/L, nanograms per liter, $\mu \mathrm{S} / \mathrm{cm}$, microsiemens per centimeter; ${ }^{\circ} \mathrm{C}$, degrees Celsius; USGS, U.S. Geological Survey; N, Nitrogen; P, Phosphorus; NTU, Nephelometric Turbidity Unit; -- , trend not tested]

\begin{tabular}{|c|c|c|c|c|c|c|c|c|c|c|c|c|}
\hline $\begin{array}{l}\text { Watershed } \\
\text { number }\end{array}$ & Site & $\begin{array}{l}\text { USGS } \\
\text { station } \\
\text { number }\end{array}$ & Constituent & $\begin{array}{c}\text { Number } \\
\text { of } \\
\text { samples } \\
\text { collected }\end{array}$ & $\begin{array}{l}\text { Number of } \\
\text { censored } \\
\text { results }\end{array}$ & $\begin{array}{c}\text { Minimum } \\
\text { concen- } \\
\text { tration }\end{array}$ & $\begin{array}{c}\text { Median } \\
\text { concen- } \\
\text { tration }\end{array}$ & $\begin{array}{c}\text { Maximum } \\
\text { concen- } \\
\text { tration }\end{array}$ & $\begin{array}{c}\text { Years } \\
\text { of data } \\
\text { used }\end{array}$ & $\begin{array}{c}\text { Seasons } \\
\text { used }\end{array}$ & $\begin{array}{l}\text { Trend } \\
\text { as a } \\
\text { percent- } \\
\text { age }\end{array}$ & $\begin{array}{c}\text { P-value } \\
\text { of } \\
\text { trend }\end{array}$ \\
\hline 6 & Tahquamenon River at Emerson & 04045510 & Lead $(\mu \mathrm{g} / \mathrm{L})$ & 44 & 0 & 0.031 & 0.1685 & 0.543 & 7 & 3 & 4.50 & 1.00 \\
\hline 6 & Tahquamenon River at Emerson & 04045510 & Mercury (ng/L) & 44 & 0 & 0.63 & 3.09 & 9.632 & 7 & 3 & 2.79 & 0.47 \\
\hline 6 & Tahquamenon River at Emerson & 04045510 & Nitrate (mg/L as N) & 44 & 0 & 0.015 & 0.0735 & 0.106 & 7 & 3 & 1.61 & 0.34 \\
\hline 6 & Tahquamenon River at Emerson & 04045510 & Nitrite $(\mathrm{mg} / \mathrm{L}$ as $\mathrm{N})$ & 44 & 1 & 0.001 & 0.004 & 0.011 & 7 & 3 & 3.00 & 0.75 \\
\hline 6 & Tahquamenon River at Emerson & 04045510 & $\mathrm{pH}$ & 42 & 0 & 6.51 & 7.43 & 8.1 & 7 & 3 & 0.16 & 0.57 \\
\hline 6 & Tahquamenon River at Emerson & 04045510 & Total phosphorus (mg/L as $\mathrm{P}$ ) & 44 & 0 & 0.011 & 0.022 & 0.042 & 7 & 3 & -0.80 & 0.70 \\
\hline 6 & Tahquamenon River at Emerson & 04045510 & Specific conductance $(\mu \mathrm{S} / \mathrm{cm})$ & 44 & 0 & 44 & 149.5 & 215 & 7 & 3 & -0.02 & 0.83 \\
\hline 6 & Tahquamenon River at Emerson & 04045510 & $\begin{array}{l}\text { Total Kjehldahl nitrogen } \\
(\mathrm{mg} / \mathrm{L} \text { as } \mathrm{N})\end{array}$ & 44 & 0 & 0.28 & 0.54 & 1.02 & 7 & 3 & -2.19 & 0.72 \\
\hline 6 & Tahquamenon River at Emerson & 04045510 & Total suspended solids (mg/L) & 44 & 22 & 2 & 4 & 29 & -- & -- & -- & -- \\
\hline 6 & Tahquamenon River at Emerson & 04045510 & Turbidity (NTU) & 31 & 0 & 2 & 3.2 & 13 & 6 & 3 & 2.66 & 0.55 \\
\hline 6 & Tahquamenon River at Emerson & 04045510 & Water temperature $\left({ }^{\circ} \mathrm{C}\right)$ & 44 & 0 & 1 & 16.6 & 23.4 & 7 & 3 & -4.67 & 0.10 \\
\hline 7 & Pine River near Charles & 04127925 & $\begin{array}{l}\text { Ammonia } \\
\qquad(\mathrm{mg} / \mathrm{L} \text { as } \mathrm{N})\end{array}$ & 31 & 1 & 0.009 & 0.017 & 0.11 & 6 & 2 & -2.62 & 1.00 \\
\hline 7 & Pine River near Charles & 04127925 & Chloride (mg/L) & 31 & 0 & 1 & 3 & 6 & 6 & 2 & 8.41 & 0.39 \\
\hline 7 & Pine River near Charles & 04127925 & Chromium $(\mu \mathrm{g} / \mathrm{L})$ & 31 & 0 & 0.709 & 1.29 & 8.08 & 6 & 2 & -1.74 & 1.00 \\
\hline 7 & Pine River near Charles & 04127925 & Copper $(\mu \mathrm{g} / \mathrm{L})$ & 31 & 0 & 0.649 & 1.21 & 6.12 & 6 & 2 & -0.36 & 1.00 \\
\hline 7 & Pine River near Charles & 04127925 & Dissolved oxygen $(\mathrm{mg} / \mathrm{L})$ & 31 & 0 & 6.9 & 9.4 & 12.9 & 6 & 2 & 1.95 & 0.74 \\
\hline 7 & Pine River near Charles & 04127925 & Lead $(\mu \mathrm{g} / \mathrm{L})$ & 31 & 0 & 0.309 & 0.545 & 4.17 & 6 & 2 & 0.93 & 0.79 \\
\hline 7 & Pine River near Charles & 04127925 & Mercury (ng/L) & 31 & 0 & 0.2 & 2.29 & 17.76 & 6 & 2 & -1.72 & 0.60 \\
\hline 7 & Pine River near Charles & 04127925 & Nitrate (mg/L as N) & 30 & 9 & 0.008 & 0.021 & 0.16 & -- & -- & -- & -- \\
\hline 7 & Pine River near Charles & 04127925 & Nitrite (mg/L as N) & 31 & 13 & 0.002 & 0.01 & 0.031 & -- & -- & -- & -- \\
\hline 7 & Pine River near Charles & 04127925 & $\mathrm{pH}$ & 30 & 0 & 7.3 & 7.8 & 8.5 & 6 & 2 & 0.14 & 1.00 \\
\hline 7 & Pine River near Charles & 04127925 & Total phosphorus (mg/L as $\mathrm{P}$ ) & 31 & 0 & 0.036 & 0.067 & 0.39 & 6 & 2 & -0.18 & 1.00 \\
\hline 7 & Pine River near Charles & 04127925 & Specific conductance $(\mu \mathrm{S} / \mathrm{cm})$ & 31 & 0 & 90 & 189 & 245 & 6 & 2 & 0.35 & 0.24 \\
\hline 7 & Pine River near Charles & 04127925 & $\begin{array}{l}\text { Total Kjehldahl nitrogen } \\
(\mathrm{mg} / \mathrm{L} \text { as } \mathrm{N})\end{array}$ & 31 & 0 & 0.3 & 0.42 & 1.11 & 6 & 2 & -2.16 & 0.60 \\
\hline 7 & Pine River near Charles & 04127925 & Total suspended solids (mg/L) & 31 & 0 & 11 & 24 & 460 & 6 & 2 & 0.31 & 1.00 \\
\hline 7 & Pine River near Charles & 04127925 & Turbidity (NTU) & 31 & 0 & 13 & 31 & 350 & 6 & 2 & 6.15 & 0.61 \\
\hline 7 & Pine River near Charles & 04127925 & Water temperature $\left({ }^{\circ} \mathrm{C}\right)$ & 31 & 0 & 1 & 15 & 26.1 & 6 & 2 & -10.95 & 0.12 \\
\hline
\end{tabular}


Appendix 1. Summary of data collected at select Michigan Water-Chemistry Monitoring Progam stream sites, 1999-2005.—Continued $\left[\mathrm{mg} / \mathrm{L}\right.$, milligrams per liter; $\mu \mathrm{g} / \mathrm{L}$, micrograms per liter, ng/L, nanograms per liter, $\mu \mathrm{S} / \mathrm{cm}$, microsiemens per centimeter; ${ }^{\circ} \mathrm{C}$, degrees Celsius; USGS, U.S. Geological Survey; N, Nitrogen; P, Phosphorus; NTU, Nephelometric Turbidity Unit; -- , trend not tested]

\begin{tabular}{|c|c|c|c|c|c|c|c|c|c|c|c|c|}
\hline $\begin{array}{c}\text { Watershed } \\
\text { number }\end{array}$ & Site & $\begin{array}{l}\text { USGS } \\
\text { station } \\
\text { number }\end{array}$ & Constituent & $\begin{array}{c}\text { Number } \\
\text { of } \\
\text { samples } \\
\text { collected }\end{array}$ & $\begin{array}{l}\text { Number of } \\
\text { censored } \\
\text { results }\end{array}$ & $\begin{array}{c}\text { Minimum } \\
\text { concen- } \\
\text { tration }\end{array}$ & $\begin{array}{c}\text { Median } \\
\text { concen- } \\
\text { tration }\end{array}$ & $\begin{array}{c}\text { Maximum } \\
\text { concen- } \\
\text { tration }\end{array}$ & $\begin{array}{c}\text { Years } \\
\text { of data } \\
\text { used }\end{array}$ & $\begin{array}{c}\text { Seasons } \\
\text { used }\end{array}$ & $\begin{array}{l}\text { Trend } \\
\text { as a } \\
\text { percent- } \\
\text { age }\end{array}$ & $\begin{array}{c}\text { P-value } \\
\text { of } \\
\text { trend }\end{array}$ \\
\hline 8 & Cheboygan River at Cheboygan & 04132052 & $\begin{array}{l}\text { Ammonia } \\
\quad(\mathrm{mg} / \mathrm{L} \text { as } \mathrm{N})\end{array}$ & 34 & 1 & 0.01 & 0.0165 & 0.035 & 6 & 3 & -0.14 & 0.90 \\
\hline 8 & Cheboygan River at Cheboygan & 04132052 & Chloride (mg/L) & 34 & 0 & 6 & 8 & 16 & 6 & 3 & 2.96 & 0.13 \\
\hline 8 & Cheboygan River at Cheboygan & 04132052 & Chromium $(\mu \mathrm{g} / \mathrm{L})$ & 33 & 16 & 0.033 & 0.081 & 0.24 & -- & -- & -- & -- \\
\hline 8 & Cheboygan River at Cheboygan & 04132052 & Copper $(\mu \mathrm{g} / \mathrm{L})$ & 33 & 0 & 0.27 & 0.55 & 0.969 & 6 & 3 & 3.49 & 0.30 \\
\hline 8 & Cheboygan River at Cheboygan & 04132052 & Dissolved oxygen (mg/L) & 32 & 0 & 7.2 & 9.05 & 13 & 6 & 3 & -0.54 & 0.73 \\
\hline 8 & Cheboygan River at Cheboygan & 04132052 & Lead $(\mu \mathrm{g} / \mathrm{L})$ & 33 & 0 & 0.0178 & 0.0413 & 0.408 & 6 & 3 & 4.96 & 0.45 \\
\hline 8 & Cheboygan River at Cheboygan & 04132052 & Mercury (ng/L) & 34 & 0 & 0.1 & 0.435 & 1.43 & 6 & 3 & 12.53 & 0.33 \\
\hline 8 & Cheboygan River at Cheboygan & 04132052 & Nitrate $(\mathrm{mg} / \mathrm{L}$ as $\mathrm{N})$ & 32 & 6 & 0.01 & 0.031 & 0.143 & -- & -- & -- & -- \\
\hline 8 & Cheboygan River at Cheboygan & 04132052 & Nitrite (mg/L as N) & 33 & 21 & 0.002 & 0.01 & 0.01 & -- & -- & -- & -- \\
\hline 8 & Cheboygan River at Cheboygan & 04132052 & $\mathrm{pH}$ & 31 & 0 & 7.5 & 8.2 & 8.4 & 6 & 3 & -0.51 & 0.31 \\
\hline 8 & Cheboygan River at Cheboygan & 04132052 & Total phosphorus (mg/L as $\mathrm{P}$ ) & 34 & 7 & 0.005 & 0.01 & 0.04 & -- & -- & -- & -- \\
\hline 8 & Cheboygan River at Cheboygan & 04132052 & Specific conductance $(\mu \mathrm{S} / \mathrm{cm})$ & 33 & 0 & 288 & 314 & 336 & 6 & 3 & -0.08 & 0.52 \\
\hline 8 & Cheboygan River at Cheboygan & 04132052 & $\begin{array}{l}\text { Total Kjehldahl nitrogen } \\
(\mathrm{mg} / \mathrm{L} \text { as } \mathrm{N})\end{array}$ & 34 & 0 & 0.21 & 0.28 & 0.37 & 6 & 3 & -2.00 & 0.74 \\
\hline 8 & Cheboygan River at Cheboygan & 04132052 & Total suspended solids (mg/L) & 33 & 22 & 1 & 4 & 7 & -- & -- & -- & -- \\
\hline 8 & Cheboygan River at Cheboygan & 04132052 & Turbidity (NTU) & 33 & 21 & 0.4 & 1 & 3.2 & -- & -- & -- & -- \\
\hline 8 & Cheboygan River at Cheboygan & 04132052 & Water temperature $\left({ }^{\circ} \mathrm{C}\right)$ & 34 & 0 & 2.3 & 20.3 & 28.1 & 6 & 3 & -0.08 & 1.00 \\
\hline 10 & Manistee River at Parkdale & 04126010 & $\begin{array}{l}\text { Ammonia } \\
\quad(\mathrm{mg} / \mathrm{L} \text { as } \mathrm{N})\end{array}$ & 31 & 0 & 0.007 & 0.019 & 0.032 & 6 & 3 & -3.80 & 0.28 \\
\hline 10 & Manistee River at Parkdale & 04126010 & Chloride (mg/L) & 31 & 0 & 8 & 11 & 33 & 6 & 3 & 3.86 & 0.47 \\
\hline 10 & Manistee River at Parkdale & 04126010 & Chromium $(\mu \mathrm{g} / \mathrm{L})$ & 31 & 2 & 0.04 & 0.223 & 0.418 & 6 & 3 & -6.74 & 0.29 \\
\hline 10 & Manistee River at Parkdale & 04126010 & Copper $(\mu \mathrm{g} / \mathrm{L})$ & 31 & 0 & 0.223 & 0.444 & 0.775 & 6 & 3 & 10.78 & 0.12 \\
\hline 10 & Manistee River at Parkdale & 04126010 & Dissolved oxygen $(\mathrm{mg} / \mathrm{L})$ & 30 & 0 & 7.5 & 9.05 & 12.8 & 6 & 2 & -5.49 & 0.29 \\
\hline 10 & Manistee River at Parkdale & 04126010 & Lead $(\mu \mathrm{g} / \mathrm{L})$ & 31 & 0 & 0.072 & 0.178 & 0.298 & 6 & 3 & 5.49 & 0.06 \\
\hline 10 & Manistee River at Parkdale & 04126010 & Mercury (ng/L) & 31 & 0 & 0.28 & 1.06 & 3.39 & 6 & 3 & 5.02 & 0.34 \\
\hline 10 & Manistee River at Parkdale & 04126010 & Nitrate (mg/L as N) & 31 & 0 & 0.099 & 0.148 & 0.28 & 6 & 3 & 0.18 & 1.00 \\
\hline 10 & Manistee River at Parkdale & 04126010 & Nitrite $(\mathrm{mg} / \mathrm{L}$ as $\mathrm{N})$ & 31 & 0 & 0.002 & 0.005 & 0.008 & 6 & 3 & 4.21 & 0.07 \\
\hline 10 & Manistee River at Parkdale & 04126010 & $\mathrm{pH}$ & 31 & 0 & 7.5 & 7.9 & 8.2 & 6 & 3 & -0.05 & 1.00 \\
\hline 10 & Manistee River at Parkdale & 04126010 & Total phosphorus (mg/L as $\mathrm{P}$ ) & 31 & 0 & 0.015 & 0.021 & 0.037 & 6 & 3 & 4.28 & 0.06 \\
\hline 10 & Manistee River at Parkdale & 04126010 & Specific conductance $(\mu \mathrm{S} / \mathrm{cm})$ & 31 & 0 & 266 & 312 & 353 & 6 & 3 & 0.36 & 0.39 \\
\hline
\end{tabular}


Appendix 1. Summary of data collected at select Michigan Water-Chemistry Monitoring Progam stream sites, 1999-2005.-Continued

$\left[\mathrm{mg} / \mathrm{L}\right.$, milligrams per liter; $\mu \mathrm{g} / \mathrm{L}$, micrograms per liter, ng/L, nanograms per liter, $\mu \mathrm{S} / \mathrm{cm}$, microsiemens per centimeter; ${ }^{\circ} \mathrm{C}$, degrees Celsius; USGS, U.S. Geological Survey; N, Nitrogen; P, Phosphorus; NTU, Nephelometric Turbidity Unit; -- , trend not tested]

\begin{tabular}{|c|c|c|c|c|c|c|c|c|c|c|c|c|}
\hline $\begin{array}{l}\text { Watershed } \\
\text { number }\end{array}$ & Site & $\begin{array}{l}\text { USGS } \\
\text { station } \\
\text { number }\end{array}$ & Constituent & $\begin{array}{c}\text { Number } \\
\text { of } \\
\text { samples } \\
\text { collected }\end{array}$ & $\begin{array}{l}\text { Number of } \\
\text { censored } \\
\text { results }\end{array}$ & $\begin{array}{c}\text { Minimum } \\
\text { concen- } \\
\text { tration }\end{array}$ & $\begin{array}{l}\text { Median } \\
\text { concen- } \\
\text { tration }\end{array}$ & $\begin{array}{c}\text { Maximum } \\
\text { concen- } \\
\text { tration }\end{array}$ & $\begin{array}{c}\text { Years } \\
\text { of data } \\
\text { used }\end{array}$ & $\begin{array}{c}\text { Seasons } \\
\text { used }\end{array}$ & $\begin{array}{l}\text { Trend } \\
\text { as a } \\
\text { percent- } \\
\text { age }\end{array}$ & $\begin{array}{c}\text { P-value } \\
\text { of } \\
\text { trend }\end{array}$ \\
\hline 10 & Manistee River at Parkdale & 04126010 & $\begin{array}{l}\text { Total Kjehldahl nitrogen } \\
\quad(\mathrm{mg} / \mathrm{L} \text { as } \mathrm{N})\end{array}$ & 31 & 0 & 0.16 & 0.25 & 0.8 & 6 & 3 & 0.22 & 0.88 \\
\hline 10 & Manistee River at Parkdale & 04126010 & Total suspended solids (mg/L) & 31 & 2 & 4 & 10 & 16 & 6 & 3 & 10.37 & 0.08 \\
\hline 10 & Manistee River at Parkdale & 04126010 & Turbidity (NTU) & 31 & 0 & 2.1 & 5.3 & 11 & 6 & 3 & 7.76 & 0.34 \\
\hline 10 & Manistee River at Parkdale & 04126010 & Water temperature $\left({ }^{\circ} \mathrm{C}\right)$ & 31 & 0 & 0.1 & 15.3 & 23.3 & 6 & 3 & 4.49 & 0.20 \\
\hline 11 & Pere Marquette River at Scottville & 04122500 & Ammonia (mg/L as N) & 47 & 0 & 0.009 & 0.02 & 0.046 & 7 & 4 & -6.13 & 0.22 \\
\hline 11 & Pere Marquette River at Scottville & 04122500 & Chloride (mg/L) & 47 & 0 & 5 & 13 & 51 & 7 & 4 & 1.81 & 0.14 \\
\hline 11 & Pere Marquette River at Scottville & 04122500 & Chromium $(\mu \mathrm{g} / \mathrm{L})$ & 47 & 0 & 0.01832 & 0.368 & 0.878 & 7 & 4 & -16.35 & 0.12 \\
\hline 11 & Pere Marquette River at Scottville & 04122500 & Copper $(\mu \mathrm{g} / \mathrm{L})$ & 47 & 0 & 0.241 & 0.47 & 1.24 & 7 & 4 & 4.02 & 0.40 \\
\hline 11 & Pere Marquette River at Scottville & 04122500 & Dissolved oxygen (mg/L) & 46 & 0 & 5.2 & 9.41 & 13.4 & 7 & 4 & -0.69 & 0.81 \\
\hline 11 & Pere Marquette River at Scottville & 04122500 & Lead $(\mu \mathrm{g} / \mathrm{L})$ & 47 & 0 & 0.0514 & 0.271 & 0.683 & 7 & 4 & -4.77 & 0.53 \\
\hline 11 & Pere Marquette River at Scottville & 04122500 & Mercury (ng/L) & 47 & 0 & 0.46 & 1.84 & 5.312 & 7 & 4 & -4.66 & 0.33 \\
\hline 11 & Pere Marquette River at Scottville & 04122500 & Nitrate (mg/L as N) & 47 & 0 & 0.042 & 0.104 & 0.32 & 7 & 4 & 2.14 & 0.78 \\
\hline 11 & Pere Marquette River at Scottville & 04122500 & Nitrite $(\mathrm{mg} / \mathrm{L}$ as $\mathrm{N})$ & 47 & 0 & 0.002 & 0.004 & 0.013 & 7 & 4 & -0.33 & 1.00 \\
\hline 11 & Pere Marquette River at Scottville & 04122500 & $\mathrm{pH}$ & 47 & 0 & 7 & 7.85 & 8.18 & 7 & 4 & 0.28 & 0.43 \\
\hline 11 & Pere Marquette River at Scottville & 04122500 & Total phosphorus (mg/L as $\mathrm{P}$ ) & 47 & 0 & 0.017 & 0.033 & 0.069 & 7 & 4 & -5.97 & 0.07 \\
\hline 11 & Pere Marquette River at Scottville & 04122500 & Specific conductance $(\mu \mathrm{S} / \mathrm{cm})$ & 46 & 0 & 220 & 340 & 387 & 7 & 4 & 0.23 & 0.94 \\
\hline 11 & Pere Marquette River at Scottville & 04122500 & $\begin{array}{l}\text { Total Kjehldahl nitrogen } \\
(\mathrm{mg} / \mathrm{L} \text { as } \mathrm{N})\end{array}$ & 47 & 0 & 0.13 & 0.36 & 0.91 & 7 & 4 & -4.25 & 0.26 \\
\hline 11 & Pere Marquette River at Scottville & 04122500 & Total suspended solids (mg/L) & 47 & 4 & 4 & 12 & 75 & -- & -- & -- & -- \\
\hline 11 & Pere Marquette River at Scottville & 04122500 & Turbidity (NTU) & 47 & 12 & 0 & 4.1 & 16 & -- & -- & -- & -- \\
\hline 11 & Pere Marquette River at Scottville & 04122500 & Water temperature $\left({ }^{\circ} \mathrm{C}\right)$ & 47 & 0 & 1.7 & 15.4 & 21.9 & 7 & 4 & -2.52 & 0.42 \\
\hline 12 & Muskegon River near Bridgeton & 04122030 & $\begin{array}{l}\text { Ammonia } \\
\quad(\mathrm{mg} / \mathrm{L} \text { as } \mathrm{N})\end{array}$ & 78 & 0 & 0.008 & 0.021 & 0.099 & 7 & 12 & -3.56 & 0.64 \\
\hline 12 & Muskegon River near Bridgeton & 04122030 & Chloride (mg/L) & 78 & 0 & 12 & 18.5 & 26 & 7 & 12 & 0.99 & 0.38 \\
\hline 12 & Muskegon River near Bridgeton & 04122030 & Chromium $(\mu \mathrm{g} / \mathrm{L})$ & 78 & 10 & 0 & 0.152 & 1.88 & -- & -- & -- & -- \\
\hline 12 & Muskegon River near Bridgeton & 04122030 & Copper $(\mu \mathrm{g} / \mathrm{L})$ & 78 & 0 & 0.338 & 0.627 & 1.98 & 7 & 12 & 4.84 & 0.08 \\
\hline 12 & Muskegon River near Bridgeton & 04122030 & Dissolved oxygen (mg/L) & 75 & 0 & 6.42 & 9.4 & 13.4 & 7 & 12 & 1.23 & 0.30 \\
\hline 12 & Muskegon River near Bridgeton & 04122030 & Lead $(\mu \mathrm{g} / \mathrm{L})$ & 78 & 0 & 0.0406 & 0.1465 & 2.18 & 7 & 12 & -1.66 & 0.66 \\
\hline 12 & Muskegon River near Bridgeton & 04122030 & Mercury (ng/L) & 78 & 0 & 0.23 & 1.101 & 34.004 & 7 & 12 & -0.80 & 1.00 \\
\hline 12 & Muskegon River near Bridgeton & 04122030 & Nitrate $(\mathrm{mg} / \mathrm{L}$ as $\mathrm{N})$ & 78 & 0 & 0.042 & 0.3 & 0.68 & 7 & 12 & -0.76 & 0.75 \\
\hline 12 & Muskegon River near Bridgeton & 04122030 & Nitrite $(\mathrm{mg} / \mathrm{L}$ as $\mathrm{N})$ & 78 & 0 & 0.003 & 0.007 & 0.021 & 7 & 12 & 2.77 & 0.30 \\
\hline
\end{tabular}


Appendix 1. Summary of data collected at select Michigan Water-Chemistry Monitoring Progam stream sites, 1999-2005.-Continued

$\left[\mathrm{mg} / \mathrm{L}\right.$, milligrams per liter; $\mu \mathrm{g} / \mathrm{L}$, micrograms per liter, ng/L, nanograms per liter, $\mu \mathrm{S} / \mathrm{cm}$, microsiemens per centimeter; ${ }^{\circ} \mathrm{C}$, degrees Celsius; USGS, U.S. Geological Survey; N, Nitrogen; P, Phosphorus; NTU, Nephelometric Turbidity Unit; -- , trend not tested]

\begin{tabular}{|c|c|c|c|c|c|c|c|c|c|c|c|c|}
\hline $\begin{array}{c}\text { Watershed } \\
\text { number }\end{array}$ & Site & $\begin{array}{l}\text { USGS } \\
\text { station } \\
\text { number }\end{array}$ & Constituent & $\begin{array}{c}\text { Number } \\
\text { of } \\
\text { samples } \\
\text { collected }\end{array}$ & $\begin{array}{c}\text { Number of } \\
\text { censored } \\
\text { results }\end{array}$ & $\begin{array}{c}\text { Minimum } \\
\text { concen- } \\
\text { tration }\end{array}$ & $\begin{array}{c}\text { Median } \\
\text { concen- } \\
\text { tration }\end{array}$ & $\begin{array}{c}\text { Maximum } \\
\text { concen- } \\
\text { tration }\end{array}$ & $\begin{array}{c}\text { Years } \\
\text { of data } \\
\text { used }\end{array}$ & $\begin{array}{c}\text { Seasons } \\
\text { used }\end{array}$ & $\begin{array}{l}\text { Trend } \\
\text { as a } \\
\text { percent- } \\
\text { age }\end{array}$ & $\begin{array}{c}\text { P-value } \\
\text { of } \\
\text { trend }\end{array}$ \\
\hline 12 & Muskegon River near Bridgeton & 04122030 & $\mathrm{pH}$ & 77 & 0 & 7.12 & 7.9 & 9 & 7 & 12 & 0.45 & 0.07 \\
\hline 12 & Muskegon River near Bridgeton & 04122030 & Total phosphorus (mg/L as $\mathrm{P}$ ) & 78 & 0 & 0.006 & 0.026 & 0.186 & 7 & 12 & -1.10 & 0.76 \\
\hline 12 & Muskegon River near Bridgeton & 04122030 & Specific conductance $(\mu \mathrm{S} / \mathrm{cm})$ & 76 & 0 & 260 & 360.5 & 425 & 7 & 12 & 0.43 & 0.66 \\
\hline 12 & Muskegon River near Bridgeton & 04122030 & $\begin{array}{l}\text { Total Kjehldahl nitrogen } \\
(\mathrm{mg} / \mathrm{L} \text { as } \mathrm{N})\end{array}$ & 78 & 0 & 0.24 & 0.4 & 0.93 & 7 & 12 & -2.57 & 0.27 \\
\hline 12 & Muskegon River near Bridgeton & 04122030 & Total suspended solids (mg/L) & 78 & 4 & 0 & 10 & 97 & -- & -- & -- & -- \\
\hline 12 & Muskegon River near Bridgeton & 04122030 & Turbidity (NTU) & 68 & 12 & 0 & 2.6 & 58 & -- & -- & -- & -- \\
\hline 12 & Muskegon River near Bridgeton & 04122030 & Water temperature $\left({ }^{\circ} \mathrm{C}\right)$ & 77 & 0 & 0.8 & 14.7 & 25.1 & 7 & 12 & -3.56 & 0.19 \\
\hline 13 & Muskegon River near Hersey & 04121621 & $\begin{array}{l}\text { Ammonia } \\
\qquad(\mathrm{mg} / \mathrm{L} \text { as } \mathrm{N})\end{array}$ & 32 & 0 & 0.007 & 0.0165 & 0.089 & 6 & 3 & 2.63 & 0.41 \\
\hline 13 & Muskegon River near Hersey & 04121621 & Chloride (mg/L) & 32 & 0 & 2 & 15.5 & 72 & 6 & 3 & 6.34 & 0.06 \\
\hline 13 & Muskegon River near Hersey & 04121621 & Chromium $(\mu \mathrm{g} / \mathrm{L})$ & 32 & 3 & 0.036 & 0.232 & 1.75 & -- & -- & -- & -- \\
\hline 13 & Muskegon River near Hersey & 04121621 & Copper $(\mu \mathrm{g} / \mathrm{L})$ & 32 & 0 & 0.34 & 0.5685 & 2.23 & 6 & 3 & 6.68 & 0.07 \\
\hline 13 & Muskegon River near Hersey & 04121621 & Dissolved oxygen (mg/L) & 31 & 0 & 7.7 & 9.3 & 13.1 & 6 & 2 & -4.53 & 0.31 \\
\hline 13 & Muskegon River near Hersey & 04121621 & Lead $(\mu \mathrm{g} / \mathrm{L})$ & 32 & 0 & 0.053 & 0.202 & 2.55 & 6 & 3 & 7.95 & 0.25 \\
\hline 13 & Muskegon River near Hersey & 04121621 & Mercury (ng/L) & 32 & 0 & 0.57 & 1.54 & 13.71 & 6 & 3 & 5.40 & 0.16 \\
\hline 13 & Muskegon River near Hersey & 04121621 & Nitrate (mg/L as N) & 32 & 0 & 0.095 & 0.1895 & 0.31 & 6 & 3 & 4.70 & 0.66 \\
\hline 13 & Muskegon River near Hersey & 04121621 & Nitrite (mg/L as N) & 32 & 0 & 0.003 & 0.005 & 0.012 & 6 & 3 & 13.12 & 0.09 \\
\hline 13 & Muskegon River near Hersey & 04121621 & $\mathrm{pH}$ & 32 & 0 & 7.3 & 7.8 & 8.29 & 6 & 3 & 0.17 & 0.72 \\
\hline 13 & Muskegon River near Hersey & 04121621 & Total phosphorus (mg/L as $\mathrm{P}$ ) & 32 & 0 & 0.013 & 0.031 & 0.183 & 6 & 3 & 3.87 & 0.23 \\
\hline 13 & Muskegon River near Hersey & 04121621 & Specific conductance $(\mu \mathrm{S} / \mathrm{cm})$ & 32 & 0 & 183 & 311 & 403 & 6 & 3 & -1.25 & 0.50 \\
\hline 13 & Muskegon River near Hersey & 04121621 & $\begin{array}{l}\text { Total Kjehldahl nitrogen } \\
(\mathrm{mg} / \mathrm{L} \text { as } \mathrm{N})\end{array}$ & 32 & 0 & 0.22 & 0.44 & 1.18 & 6 & 3 & 3.69 & 0.44 \\
\hline 13 & Muskegon River near Hersey & 04121621 & Total suspended solids (mg/L) & 32 & 3 & 4 & 10.5 & 100 & -- & -- & -- & -- \\
\hline 13 & Muskegon River near Hersey & 04121621 & Turbidity (NTU) & 32 & 0 & 1.3 & 4.45 & 49 & 6 & 3 & 6.09 & 0.58 \\
\hline 13 & Muskegon River near Hersey & 04121621 & Water temperature $\left({ }^{\circ} \mathrm{C}\right)$ & 32 & 0 & 1.2 & 15.65 & 21.4 & 6 & 3 & 6.87 & 0.24 \\
\hline 14 & Grand River near Eastmanville & 04119400 & $\begin{array}{l}\text { Ammonia } \\
\quad(\mathrm{mg} / \mathrm{L} \text { as } \mathrm{N})\end{array}$ & 79 & 0 & 0.011 & 0.095 & 0.81 & 7 & 12 & 5.99 & 0.08 \\
\hline 14 & Grand River near Eastmanville & 04119400 & Chloride (mg/L) & 79 & 0 & 24 & 54 & 77 & 7 & 12 & 1.04 & 0.26 \\
\hline 14 & Grand River near Eastmanville & 04119400 & Chromium $(\mu \mathrm{g} / \mathrm{L})$ & 78 & 0 & 0.147 & 0.895 & 4.73 & 7 & 12 & -13.54 & 0.04 \\
\hline 14 & Grand River near Eastmanville & 04119400 & Copper $(\mu \mathrm{g} / \mathrm{L})$ & 79 & 0 & 1.18 & 2.35 & 393 & 7 & 12 & 0.37 & 1.00 \\
\hline 14 & Grand River near Eastmanville & 04119400 & Dissolved oxygen (mg/L) & 78 & 0 & 6.3 & 10.3 & 16.9 & 7 & 12 & 3.11 & 0.04 \\
\hline
\end{tabular}


Appendix 1. Summary of data collected at select Michigan Water-Chemistry Monitoring Progam stream sites, 1999-2005.—Continued

$\left[\mathrm{mg} / \mathrm{L}\right.$, milligrams per liter; $\mu \mathrm{g} / \mathrm{L}$, micrograms per liter, ng/L, nanograms per liter, $\mu \mathrm{S} / \mathrm{cm}$, microsiemens per centimeter; ${ }^{\circ} \mathrm{C}$, degrees Celsius; USGS, U.S. Geological Survey; N, Nitrogen; P, Phosphorus; NTU, Nephelometric Turbidity Unit; -- , trend not tested]

\begin{tabular}{|c|c|c|c|c|c|c|c|c|c|c|c|c|}
\hline $\begin{array}{l}\text { Watershed } \\
\text { number }\end{array}$ & Site & $\begin{array}{l}\text { USGS } \\
\text { station } \\
\text { number }\end{array}$ & Constituent & $\begin{array}{c}\text { Number } \\
\text { of } \\
\text { samples } \\
\text { collected }\end{array}$ & $\begin{array}{l}\text { Number of } \\
\text { censored } \\
\text { results }\end{array}$ & $\begin{array}{c}\text { Minimum } \\
\text { concen- } \\
\text { tration }\end{array}$ & $\begin{array}{l}\text { Median } \\
\text { concen- } \\
\text { tration }\end{array}$ & $\begin{array}{c}\text { Maximum } \\
\text { concen- } \\
\text { tration }\end{array}$ & $\begin{array}{l}\text { Years } \\
\text { of data } \\
\text { used }\end{array}$ & $\begin{array}{l}\text { Seasons } \\
\text { used }\end{array}$ & $\begin{array}{l}\text { Trend } \\
\text { as a } \\
\text { percent- } \\
\text { age }\end{array}$ & $\begin{array}{c}\text { P-value } \\
\text { of } \\
\text { trend }\end{array}$ \\
\hline 14 & Grand River near Eastmanville & 04119400 & Lead $(\mu \mathrm{g} / \mathrm{L})$ & 79 & 0 & 0.293 & 1.12 & 5.38 & 7 & 12 & -3.36 & 0.26 \\
\hline 14 & Grand River near Eastmanville & 04119400 & Mercury (ng/L) & 79 & 0 & 0.66 & 3.36 & 21.813 & 7 & 12 & -1.52 & 0.48 \\
\hline 14 & Grand River near Eastmanville & 04119400 & Nitrate $(\mathrm{mg} / \mathrm{L}$ as $\mathrm{N})$ & 79 & 0 & 0.26 & 1.53 & 5.16 & 7 & 12 & -0.59 & 0.93 \\
\hline 14 & Grand River near Eastmanville & 04119400 & Nitrite $(\mathrm{mg} / \mathrm{L}$ as $\mathrm{N})$ & 79 & 0 & 0.016 & 0.032 & 0.102 & 7 & 12 & 2.92 & 0.19 \\
\hline 14 & Grand River near Eastmanville & 04119400 & $\mathrm{pH}$ & 79 & 0 & 7.2 & 8 & 8.9 & 7 & 12 & 0.46 & 0.18 \\
\hline 14 & Grand River near Eastmanville & 04119400 & Total phosphorus (mg/L as $\mathrm{P}$ ) & 79 & 0 & 0.033 & 0.109 & 0.31 & 7 & 12 & -2.04 & 0.40 \\
\hline 14 & Grand River near Eastmanville & 04119400 & Specific conductance $(\mu \mathrm{S} / \mathrm{cm})$ & 79 & 0 & 388 & 618 & 800 & 7 & 12 & 0.23 & 0.87 \\
\hline 14 & Grand River near Eastmanville & 04119400 & $\begin{array}{l}\text { Total Kjehldahl nitrogen } \\
\quad(\mathrm{mg} / \mathrm{L} \text { as } \mathrm{N})\end{array}$ & 79 & 0 & 0.64 & 1.14 & 2.7 & 7 & 12 & 0.34 & 0.83 \\
\hline 14 & Grand River near Eastmanville & 04119400 & Total suspended solids (mg/L) & 79 & 2 & 4 & 28 & 150 & 7 & 12 & -3.03 & 0.22 \\
\hline 14 & Grand River near Eastmanville & 04119400 & Turbidity (NTU) & 66 & 0 & 2.2 & 14 & 140 & 6 & 12 & -2.73 & 0.54 \\
\hline 14 & Grand River near Eastmanville & 04119400 & Water temperature $\left({ }^{\circ} \mathrm{C}\right)$ & 79 & 0 & 0.2 & 16.2 & 28.2 & 7 & 12 & -1.86 & 0.30 \\
\hline 15 & Grand River at Ionia & 04116000 & $\begin{array}{l}\text { Ammonia } \\
\quad(\mathrm{mg} / \mathrm{L} \text { as } \mathrm{N})\end{array}$ & 31 & 2 & 0.006 & 0.017 & 0.28 & 6 & 4 & -4.15 & 0.16 \\
\hline 15 & Grand River at Ionia & 04116000 & Chloride (mg/L) & 31 & 0 & 27 & 53 & 94 & 6 & 4 & 3.11 & 0.17 \\
\hline 15 & Grand River at Ionia & 04116000 & Chromium $(\mu \mathrm{g} / \mathrm{L})$ & 31 & 0 & 0.112 & 0.526 & 15.1 & 6 & 4 & -12.60 & 0.25 \\
\hline 15 & Grand River at Ionia & 04116000 & Copper $(\mu \mathrm{g} / \mathrm{L})$ & 31 & 0 & 1.44 & 2.53 & 12.4 & 6 & 4 & -2.20 & 0.90 \\
\hline 15 & Grand River at Ionia & 04116000 & Dissolved oxygen (mg/L) & 31 & 0 & 5.4 & 8.87 & 14.5 & 6 & 2 & 2.72 & 1.00 \\
\hline 15 & Grand River at Ionia & 04116000 & Lead $(\mu \mathrm{g} / \mathrm{L})$ & 31 & 0 & 0.261 & 0.851 & 18 & 6 & 4 & -7.49 & 0.23 \\
\hline 15 & Grand River at Ionia & 04116000 & Mercury (ng/L) & 31 & 0 & 0.58 & 2.56 & 52.23 & 6 & 4 & -2.59 & 0.90 \\
\hline 15 & Grand River at Ionia & 04116000 & Nitrate $(\mathrm{mg} / \mathrm{L}$ as $\mathrm{N})$ & 31 & 0 & 0.055 & 1.82 & 5.4 & 6 & 4 & -4.78 & 0.89 \\
\hline 15 & Grand River at Ionia & 04116000 & Nitrite $(\mathrm{mg} / \mathrm{L}$ as $\mathrm{N})$ & 31 & 0 & 0.008 & 0.02 & 0.056 & 6 & 4 & 9.01 & 0.43 \\
\hline 15 & Grand River at Ionia & 04116000 & $\mathrm{pH}$ & 33 & 0 & 7 & 8 & 8.7 & 6 & 4 & 0.68 & 0.20 \\
\hline 15 & Grand River at Ionia & 04116000 & Total phosphorus (mg/L as $\mathrm{P}$ ) & 31 & 0 & 0.048 & 0.112 & 0.29 & 6 & 4 & 0.16 & 1.00 \\
\hline 15 & Grand River at Ionia & 04116000 & Specific conductance $(\mu \mathrm{S} / \mathrm{cm})$ & 33 & 0 & 420 & 664 & 739 & 6 & 4 & 0.97 & 0.63 \\
\hline 15 & Grand River at Ionia & 04116000 & $\begin{array}{l}\text { Total Kjehldahl nitrogen } \\
(\mathrm{mg} / \mathrm{L} \text { as } \mathrm{N})\end{array}$ & 31 & 0 & 0.55 & 1 & 1.52 & 6 & 4 & 1.75 & 0.72 \\
\hline 15 & Grand River at Ionia & 04116000 & Total suspended solids (mg/L) & 31 & 1 & 4 & 18 & 830 & 6 & 4 & -1.79 & 0.73 \\
\hline 15 & Grand River at Ionia & 04116000 & Turbidity (NTU) & 31 & 0 & 2.1 & 12 & 620 & 6 & 4 & -3.32 & 0.53 \\
\hline 15 & Grand River at Ionia & 04116000 & Water temperature $\left({ }^{\circ} \mathrm{C}\right)$ & 33 & 0 & 0.1 & 15.4 & 27.23 & 6 & 4 & 2.19 & 0.74 \\
\hline
\end{tabular}


Appendix 1. Summary of data collected at select Michigan Water-Chemistry Monitoring Progam stream sites, 1999-2005.—Continued $\left[\mathrm{mg} / \mathrm{L}\right.$, milligrams per liter; $\mu \mathrm{g} / \mathrm{L}$, micrograms per liter, ng/L, nanograms per liter, $\mu \mathrm{S} / \mathrm{cm}$, microsiemens per centimeter; ${ }^{\circ} \mathrm{C}$, degrees Celsius; USGS, U.S. Geological Survey; N, Nitrogen; P, Phosphorus; NTU, Nephelometric Turbidity Unit; -- , trend not tested]

\begin{tabular}{|c|c|c|c|c|c|c|c|c|c|c|c|c|}
\hline $\begin{array}{c}\text { Watershed } \\
\text { number }\end{array}$ & Site & $\begin{array}{l}\text { USGS } \\
\text { station } \\
\text { number }\end{array}$ & Constituent & $\begin{array}{c}\text { Number } \\
\text { of } \\
\text { samples } \\
\text { collected }\end{array}$ & $\begin{array}{l}\text { Number of } \\
\text { censored } \\
\text { results }\end{array}$ & $\begin{array}{c}\text { Minimum } \\
\text { concen- } \\
\text { tration }\end{array}$ & $\begin{array}{l}\text { Median } \\
\text { concen- } \\
\text { tration }\end{array}$ & $\begin{array}{c}\text { Maximum } \\
\text { concen- } \\
\text { tration }\end{array}$ & $\begin{array}{c}\text { Years } \\
\text { of data } \\
\text { used }\end{array}$ & $\begin{array}{c}\text { Seasons } \\
\text { used }\end{array}$ & $\begin{array}{l}\text { Trend } \\
\text { as a } \\
\text { percent- } \\
\text { age }\end{array}$ & $\begin{array}{c}\text { P-value } \\
\text { of } \\
\text { trend }\end{array}$ \\
\hline 16 & Kalamazoo River at New Richmond & 04108660 & $\begin{array}{l}\text { Ammonia } \\
\quad(\mathrm{mg} / \mathrm{L} \text { as } \mathrm{N})\end{array}$ & 79 & 0 & 0.004 & 0.048 & 0.3 & 5 & 12 & -6.47 & 0.29 \\
\hline 16 & Kalamazoo River at New Richmond & 04108660 & Chloride (mg/L) & 79 & 0 & 23 & 44 & 62 & 5 & 12 & 3.28 & 0.05 \\
\hline 16 & Kalamazoo River at New Richmond & 04108660 & Chromium $(\mu \mathrm{g} / \mathrm{L})$ & 79 & 0 & 0.05 & 0.608 & 1.912 & 5 & 12 & -13.35 & 0.04 \\
\hline 16 & Kalamazoo River at New Richmond & 04108660 & Copper $(\mu \mathrm{g} / \mathrm{L})$ & 79 & 0 & 0.806 & 1.48 & 2.74 & 5 & 12 & 3.82 & 0.39 \\
\hline 16 & Kalamazoo River at New Richmond & 04108660 & Dissolved oxygen (mg/L) & 78 & 0 & 5.9 & 8.85 & 13.7 & 5 & 12 & 5.33 & 0.17 \\
\hline 16 & Kalamazoo River at New Richmond & 04108660 & Lead $(\mu \mathrm{g} / \mathrm{L})$ & 79 & 0 & 0.387 & 1.334 & 2.51 & 5 & 12 & -4.25 & 0.54 \\
\hline 16 & Kalamazoo River at New Richmond & 04108660 & Mercury (ng/L) & 78 & 0 & 1.09 & 5.59 & 14.2 & 5 & 12 & 0.51 & 0.84 \\
\hline 16 & Kalamazoo River at New Richmond & 04108660 & Nitrate $(\mathrm{mg} / \mathrm{L}$ as $\mathrm{N})$ & 79 & 0 & 0.31 & 1.09 & 2.86 & 5 & 12 & -2.75 & 0.38 \\
\hline 16 & Kalamazoo River at New Richmond & 04108660 & Nitrite $(\mathrm{mg} / \mathrm{L}$ as $\mathrm{N})$ & 79 & 0 & 0.009 & 0.019 & 0.076 & 5 & 12 & 2.31 & 0.74 \\
\hline 16 & Kalamazoo River at New Richmond & 04108660 & $\mathrm{pH}$ & 79 & 0 & 7.2 & 7.9 & 8.8 & 5 & 12 & 0.61 & 0.29 \\
\hline 16 & Kalamazoo River at New Richmond & 04108660 & Total phosphorus (mg/L as P) & 79 & 0 & 0.024 & 0.085 & 0.192 & 5 & 12 & 1.52 & 0.46 \\
\hline 16 & Kalamazoo River at New Richmond & 04108660 & Specific conductance $(\mu \mathrm{S} / \mathrm{cm})$ & 79 & 0 & 389 & 575 & 698 & 5 & 12 & 0.44 & 0.77 \\
\hline 16 & Kalamazoo River at New Richmond & 04108660 & $\begin{array}{l}\text { Total Kjehldahl nitrogen } \\
\quad(\mathrm{mg} / \mathrm{L} \text { as } \mathrm{N})\end{array}$ & 79 & 0 & 0.47 & 0.89 & 1.36 & 5 & 12 & 0.52 & 0.92 \\
\hline 16 & Kalamazoo River at New Richmond & 04108660 & Total suspended solids (mg/L) & 79 & 3 & 2 & 20 & 50 & 5 & 12 & -4.07 & 0.70 \\
\hline 16 & Kalamazoo River at New Richmond & 04108660 & Turbidity (NTU) & 66 & 0 & 2.2 & 11.5 & 36 & 5 & 12 & 2.45 & 0.77 \\
\hline 16 & Kalamazoo River at New Richmond & 04108660 & Water temperature $\left({ }^{\circ} \mathrm{C}\right)$ & 79 & 0 & 0.1 & 16.3 & 26.7 & 5 & 12 & -4.74 & 0.45 \\
\hline 17 & Kalamazoo River near Augusta & 04105707 & $\begin{array}{l}\text { Ammonia } \\
\quad(\mathrm{mg} / \mathrm{L} \text { as } \mathrm{N})\end{array}$ & 31 & 0 & 0.013 & 0.05 & 0.15 & 6 & 4 & 7.32 & 0.20 \\
\hline 17 & Kalamazoo River near Augusta & 04105707 & Chloride (mg/L) & 31 & 0 & 13 & 41 & 56 & 6 & 4 & -0.59 & 0.12 \\
\hline 17 & Kalamazoo River near Augusta & 04105707 & Chromium $(\mu \mathrm{g} / \mathrm{L})$ & 31 & 0 & 0.105 & 0.887 & 2.83 & 6 & 4 & 0.40 & 1.00 \\
\hline 17 & Kalamazoo River near Augusta & 04105707 & Copper $(\mu \mathrm{g} / \mathrm{L})$ & 31 & 0 & 0.657 & 1.45 & 3.49 & 6 & 4 & 4.37 & 0.38 \\
\hline 17 & Kalamazoo River near Augusta & 04105707 & Dissolved oxygen (mg/L) & 29 & 0 & 6.2 & 7.5 & 12.4 & 6 & 2 & 3.87 & 0.51 \\
\hline 17 & Kalamazoo River near Augusta & 04105707 & Lead $(\mu \mathrm{g} / \mathrm{L})$ & 31 & 0 & 0.269 & 1.02 & 6.29 & 6 & 4 & 1.65 & 0.49 \\
\hline 17 & Kalamazoo River near Augusta & 04105707 & Mercury (ng/L) & 31 & 0 & 1.01 & 3.73 & 13.21 & 6 & 4 & 11.03 & 0.48 \\
\hline 17 & Kalamazoo River near Augusta & 04105707 & Nitrate (mg/L as N) & 31 & 0 & 0.65 & 0.97 & 2.38 & 6 & 4 & -3.60 & 0.27 \\
\hline 17 & Kalamazoo River near Augusta & 04105707 & Nitrite $(\mathrm{mg} / \mathrm{L}$ as $\mathrm{N})$ & 31 & 0 & 0.006 & 0.013 & 0.063 & 6 & 4 & 13.42 & 0.12 \\
\hline 17 & Kalamazoo River near Augusta & 04105707 & $\mathrm{pH}$ & 30 & 0 & 7.1 & 7.8 & 9.1 & 6 & 4 & 0.59 & 0.16 \\
\hline 17 & Kalamazoo River near Augusta & 04105707 & Total phosphorus (mg/L as $\mathrm{P}$ ) & 31 & 0 & 0.033 & 0.072 & 0.155 & 6 & 4 & -1.90 & 0.93 \\
\hline 17 & Kalamazoo River near Augusta & 04105707 & Specific conductance $(\mu \mathrm{S} / \mathrm{cm})$ & 30 & 0 & 330 & 618.5 & 689 & 6 & 4 & 0.99 & 0.44 \\
\hline
\end{tabular}


Appendix 1. Summary of data collected at select Michigan Water-Chemistry Monitoring Progam stream sites, 1999-2005.—Continued

$\left[\mathrm{mg} / \mathrm{L}\right.$, milligrams per liter; $\mu \mathrm{g} / \mathrm{L}$, micrograms per liter, $\mathrm{ng} / \mathrm{L}$, nanograms per liter, $\mu \mathrm{S} / \mathrm{cm}$, microsiemens per centimeter; ${ }^{\circ} \mathrm{C}$, degrees Celsius; USGS, U.S. Geological Survey; N, Nitrogen; P, Phosphorus; NTU, Nephelometric Turbidity Unit; -- , trend not tested]

\begin{tabular}{|c|c|c|c|c|c|c|c|c|c|c|c|c|}
\hline $\begin{array}{l}\text { Watershed } \\
\text { number }\end{array}$ & Site & $\begin{array}{l}\text { USGS } \\
\text { station } \\
\text { number }\end{array}$ & Constituent & $\begin{array}{c}\text { Number } \\
\text { of } \\
\text { samples } \\
\text { collected }\end{array}$ & $\begin{array}{l}\text { Number of } \\
\text { censored } \\
\text { results }\end{array}$ & $\begin{array}{c}\text { Minimum } \\
\text { concen- } \\
\text { tration }\end{array}$ & $\begin{array}{c}\text { Median } \\
\text { concen- } \\
\text { tration }\end{array}$ & $\begin{array}{c}\text { Maximum } \\
\text { concen- } \\
\text { tration }\end{array}$ & $\begin{array}{c}\text { Years } \\
\text { of data } \\
\text { used }\end{array}$ & $\begin{array}{c}\text { Seasons } \\
\text { used }\end{array}$ & $\begin{array}{c}\text { Trend } \\
\text { as a } \\
\text { percent- } \\
\text { age }\end{array}$ & $\begin{array}{c}\text { P-value } \\
\text { of } \\
\text { trend }\end{array}$ \\
\hline 17 & Kalamazoo River near Augusta & 04105707 & $\begin{array}{l}\text { Total Kjehldahl nitrogen } \\
(\mathrm{mg} / \mathrm{L} \text { as } \mathrm{N})\end{array}$ & 31 & 0 & 0.37 & 0.67 & 1.12 & 6 & 4 & 1.52 & 0.78 \\
\hline 17 & Kalamazoo River near Augusta & 04105707 & Total suspended solids (mg/L) & 31 & 3 & 4 & 11 & 39 & -- & -- & -- & -- \\
\hline 17 & Kalamazoo River near Augusta & 04105707 & Turbidity (NTU) & 31 & 0 & 1.5 & 6.4 & 18 & 6 & 4 & -1.33 & 0.92 \\
\hline 17 & Kalamazoo River near Augusta & 04105707 & Water temperature $\left({ }^{\circ} \mathrm{C}\right)$ & 30 & 1 & 0 & 17.25 & 25.6 & 6 & 4 & 0.04 & 1.00 \\
\hline 18 & St. Joseph River at St. Joseph & 04102080 & Ammonia $(\mathrm{mg} / \mathrm{L}$ as $\mathrm{N})$ & 51 & 2 & 0 & 0.017 & 0.31 & 7 & 4 & -5.95 & 0.60 \\
\hline 18 & St. Joseph River at St. Joseph & 04102080 & Chloride (mg/L) & 51 & 0 & 18 & 30 & 45 & 7 & 4 & 1.56 & 0.08 \\
\hline 18 & St. Joseph River at St. Joseph & 04102080 & Chromium $(\mu \mathrm{g} / \mathrm{L})$ & 51 & 1 & 0 & 0.46 & 3.87 & 7 & 4 & -13.81 & 0.05 \\
\hline 18 & St. Joseph River at St. Joseph & 04102080 & Copper $(\mu \mathrm{g} / \mathrm{L})$ & 51 & 0 & 0.865 & 1.48 & 4.92 & 7 & 4 & 3.42 & 0.02 \\
\hline 18 & St. Joseph River at St. Joseph & 04102080 & Dissolved oxygen (mg/L) & 45 & 0 & 6.6 & 9.4 & 14.9 & 7 & 4 & 3.84 & 0.07 \\
\hline 18 & St. Joseph River at St. Joseph & 04102080 & Lead $(\mu \mathrm{g} / \mathrm{L})$ & 51 & 0 & 0.338 & 0.854 & 5.2 & 7 & 4 & -3.59 & 0.29 \\
\hline 18 & St. Joseph River at St. Joseph & 04102080 & Mercury (ng/L) & 51 & 0 & 0.96 & 3.18 & 15.98 & 7 & 4 & -4.76 & 0.64 \\
\hline 18 & St. Joseph River at St. Joseph & 04102080 & Nitrate (mg/L as N) & 51 & 0 & 0.77 & 1.52 & 4.3 & 7 & 4 & 5.19 & 0.18 \\
\hline 18 & St. Joseph River at St. Joseph & 04102080 & Nitrite (mg/L as N) & 51 & 0 & 0.005 & 0.013 & 0.039 & 7 & 4 & 5.68 & 0.42 \\
\hline 18 & St. Joseph River at St. Joseph & 04102080 & $\mathrm{pH}$ & 49 & 0 & 6.8 & 7.9 & 9.2 & 7 & 4 & 0.77 & 0.20 \\
\hline 18 & St. Joseph River at St. Joseph & 04102080 & Total phosphorus (mg/L as P) & 51 & 0 & 0.034 & 0.07 & 0.4 & 7 & 4 & -5.61 & 0.11 \\
\hline 18 & St. Joseph River at St. Joseph & 04102080 & Specific conductance $(\mu \mathrm{S} / \mathrm{cm})$ & 47 & 0 & 356 & 556 & 631 & 7 & 4 & -0.18 & 0.91 \\
\hline 18 & St. Joseph River at St. Joseph & 04102080 & $\begin{array}{l}\text { Total Kjehldahl nitrogen } \\
\quad(\mathrm{mg} / \mathrm{L} \text { as } \mathrm{N})\end{array}$ & 51 & 0 & 0.31 & 0.67 & 1.67 & 7 & 4 & -2.48 & 0.15 \\
\hline 18 & St. Joseph River at St. Joseph & 04102080 & Total suspended solids (mg/L) & 51 & 1 & 4 & 18 & 97 & 7 & 4 & -13.46 & 0.29 \\
\hline 18 & St. Joseph River at St. Joseph & 04102080 & Turbidity (NTU) & 41 & 2 & 0 & 7.4 & 120 & 6 & 4 & -6.10 & 0.37 \\
\hline 18 & St. Joseph River at St. Joseph & 04102080 & Water temperature $\left({ }^{\circ} \mathrm{C}\right)$ & 49 & 0 & 1 & 17.5 & 28.8 & 7 & 4 & -5.54 & 0.11 \\
\hline 19 & St. Joseph River at Mottville & 04099000 & $\begin{array}{l}\text { Ammonia } \\
\quad(\mathrm{mg} / \mathrm{L} \text { as } \mathrm{N})\end{array}$ & 26 & 0 & 0.016 & 0.058 & 0.13 & 6 & 4 & -9.84 & 0.05 \\
\hline 19 & St. Joseph River at Mottville & 04099000 & Chloride (mg/L) & 26 & 0 & 15 & 22 & 34 & 6 & 4 & 2.62 & 0.05 \\
\hline 19 & St. Joseph River at Mottville & 04099000 & Chromium $(\mu \mathrm{g} / \mathrm{L})$ & 26 & 2 & 0.005 & 0.0905 & 0.47 & 6 & 4 & -3.62 & 0.68 \\
\hline 19 & St. Joseph River at Mottville & 04099000 & Copper $(\mu \mathrm{g} / \mathrm{L})$ & 26 & 0 & 0.322 & 0.6265 & 1.24 & 6 & 4 & 10.67 & 0.11 \\
\hline 19 & St. Joseph River at Mottville & 04099000 & Dissolved oxygen (mg/L) & 24 & 0 & 5.9 & 7.75 & 13.3 & 6 & 2 & 8.27 & 0.24 \\
\hline 19 & St. Joseph River at Mottville & 04099000 & Lead $(\mu \mathrm{g} / \mathrm{L})$ & 26 & 0 & 0.085 & 0.273 & 0.89 & 6 & 4 & 0.78 & 1.00 \\
\hline 19 & St. Joseph River at Mottville & 04099000 & Mercury (ng/L) & 26 & 0 & 0.56 & 1.22 & 7.89 & 6 & 4 & 2.80 & 0.62 \\
\hline 19 & St. Joseph River at Mottville & 04099000 & Nitrate (mg/L as N) & 26 & 0 & 0.87 & 1.43 & 2.4 & 6 & 4 & 1.32 & 0.79 \\
\hline 19 & St. Joseph River at Mottville & 04099000 & Nitrite (mg/L as $\mathrm{N})$ & 26 & 0 & 0.009 & 0.0155 & 0.032 & 6 & 4 & -0.62 & 0.72 \\
\hline
\end{tabular}


Appendix 1. Summary of data collected at select Michigan Water-Chemistry Monitoring Progam stream sites, 1999-2005.-Continued $\left[\mathrm{mg} / \mathrm{L}\right.$, milligrams per liter; $\mu \mathrm{g} / \mathrm{L}$, micrograms per liter, ng/L, nanograms per liter, $\mu \mathrm{S} / \mathrm{cm}$, microsiemens per centimeter; ${ }^{\circ} \mathrm{C}$, degrees Celsius; USGS, U.S. Geological Survey; N, Nitrogen; P, Phosphorus; NTU, Nephelometric Turbidity Unit; -- , trend not tested]

\begin{tabular}{|c|c|c|c|c|c|c|c|c|c|c|c|c|}
\hline $\begin{array}{c}\text { Watershed } \\
\text { number }\end{array}$ & Site & $\begin{array}{l}\text { USGS } \\
\text { station } \\
\text { number }\end{array}$ & Constituent & $\begin{array}{c}\text { Number } \\
\text { of } \\
\text { samples } \\
\text { collected }\end{array}$ & $\begin{array}{l}\text { Number of } \\
\text { censored } \\
\text { results }\end{array}$ & $\begin{array}{c}\text { Minimum } \\
\text { concen- } \\
\text { tration }\end{array}$ & $\begin{array}{l}\text { Median } \\
\text { concen- } \\
\text { tration }\end{array}$ & $\begin{array}{c}\text { Maximum } \\
\text { concen- } \\
\text { tration }\end{array}$ & $\begin{array}{c}\text { Years } \\
\text { of data } \\
\text { used }\end{array}$ & $\begin{array}{l}\text { Seasons } \\
\text { used }\end{array}$ & $\begin{array}{l}\text { Trend } \\
\text { as a } \\
\text { percent- } \\
\text { age }\end{array}$ & $\begin{array}{c}\text { P-value } \\
\text { of } \\
\text { trend }\end{array}$ \\
\hline 19 & St. Joseph River at Mottville & 04099000 & $\mathrm{pH}$ & 26 & 0 & 7.5 & 7.9 & 8.2 & 6 & 4 & 0.87 & 0.04 \\
\hline 19 & St. Joseph River at Mottville & 04099000 & Total phosphorus (mg/L as $\mathrm{P}$ ) & 26 & 0 & 0.012 & 0.0315 & 0.093 & 6 & 4 & 1.97 & 0.76 \\
\hline 19 & St. Joseph River at Mottville & 04099000 & Specific conductance $(\mu \mathrm{S} / \mathrm{cm})$ & 26 & 0 & 350 & 499 & 551 & 6 & 4 & 0.40 & 1.00 \\
\hline 19 & St. Joseph River at Mottville & 04099000 & $\begin{array}{l}\text { Total Kjehldahl nitrogen } \\
(\mathrm{mg} / \mathrm{L} \text { as } \mathrm{N})\end{array}$ & 26 & 0 & 0.41 & 0.525 & 0.93 & 6 & 4 & -0.02 & 1.00 \\
\hline 19 & St. Joseph River at Mottville & 04099000 & Total suspended solids $(\mathrm{mg} / \mathrm{L})$ & 26 & 7 & 4 & 6 & 20 & -- & -- & -- & -- \\
\hline 19 & St. Joseph River at Mottville & 04099000 & Turbidity (NTU) & 26 & 0 & 0.7 & 3.45 & 16 & 6 & 4 & 3.78 & 0.59 \\
\hline 19 & St. Joseph River at Mottville & 04099000 & Water temperature $\left({ }^{\circ} \mathrm{C}\right)$ & 27 & 0 & 0.02 & 18.9 & 27.3 & 6 & 4 & 0.41 & 1.00 \\
\hline 20 & River Raisin at Monroe & 04176540 & $\begin{array}{l}\text { Ammonia } \\
\qquad(\mathrm{mg} / \mathrm{L} \text { as } \mathrm{N})\end{array}$ & 31 & 7 & 0.01 & 0.042 & 0.17 & -- & -- & -- & -- \\
\hline 20 & River Raisin at Monroe & 04176540 & Chloride (mg/L) & 31 & 0 & 24 & 46 & 64 & 6 & 3 & 3.15 & 0.12 \\
\hline 20 & River Raisin at Monroe & 04176540 & Chromium $(\mu \mathrm{g} / \mathrm{L})$ & 31 & 0 & 0.096 & 0.601 & 4.23 & 6 & 3 & -10.09 & 0.30 \\
\hline 20 & River Raisin at Monroe & 04176540 & Copper $(\mu \mathrm{g} / \mathrm{L})$ & 31 & 0 & 1.6 & 2.79 & 5.55 & 6 & 3 & 1.20 & 0.76 \\
\hline 20 & River Raisin at Monroe & 04176540 & Dissolved oxygen (mg/L) & 31 & 0 & 6.1 & 9.5 & 12.9 & 6 & 2 & 2.41 & 0.63 \\
\hline 20 & River Raisin at Monroe & 04176540 & Lead $(\mu \mathrm{g} / \mathrm{L})$ & 31 & 0 & 0.275 & 0.664 & 4.19 & 6 & 3 & -7.16 & 0.59 \\
\hline 20 & River Raisin at Monroe & 04176540 & Mercury (ng/L) & 31 & 0 & 1.14 & 2.07 & 12.04 & 6 & 3 & -2.00 & 0.93 \\
\hline 20 & River Raisin at Monroe & 04176540 & Nitrate (mg/L as N) & 31 & 0 & 0.032 & 1.38 & 10.9 & 6 & 3 & 12.12 & 0.49 \\
\hline 20 & River Raisin at Monroe & 04176540 & Nitrite $(\mathrm{mg} / \mathrm{L}$ as $\mathrm{N})$ & 31 & 1 & 0.008 & 0.017 & 0.086 & 6 & 3 & 10.39 & 0.39 \\
\hline 20 & River Raisin at Monroe & 04176540 & $\mathrm{pH}$ & 32 & 0 & 7.2 & 7.935 & 8.6 & 6 & 3 & 0.25 & 0.77 \\
\hline 20 & River Raisin at Monroe & 04176540 & Total phosphorus (mg/L as $\mathrm{P}$ ) & 31 & 0 & 0.033 & 0.078 & 0.3 & 6 & 3 & -10.30 & 0.38 \\
\hline 20 & River Raisin at Monroe & 04176540 & Specific conductance $(\mu \mathrm{S} / \mathrm{cm})$ & 31 & 0 & 367 & 604 & 759 & 6 & 3 & 5.66 & 0.06 \\
\hline 20 & River Raisin at Monroe & 04176540 & $\begin{array}{l}\text { Total Kjehldahl nitrogen } \\
\quad(\mathrm{mg} / \mathrm{L} \text { as } \mathrm{N})\end{array}$ & 31 & 0 & 0.4 & 0.84 & 1.43 & 6 & 3 & 0.00 & 1.00 \\
\hline 20 & River Raisin at Monroe & 04176540 & Total suspended solids (mg/L) & 31 & 0 & 5 & 13 & 110 & 6 & 3 & -6.07 & 0.50 \\
\hline 20 & River Raisin at Monroe & 04176540 & Turbidity (NTU) & 31 & 0 & 3.9 & 11 & 150 & 6 & 3 & -2.37 & 0.93 \\
\hline 20 & River Raisin at Monroe & 04176540 & Water temperature $\left({ }^{\circ} \mathrm{C}\right)$ & 32 & 0 & 0.3 & 20.85 & 28.4 & 6 & 3 & -8.17 & 0.12 \\
\hline 21 & Huron River at Rockwood & 04175120 & $\begin{array}{l}\text { Ammonia } \\
\quad(\mathrm{mg} / \mathrm{L} \text { as } \mathrm{N})\end{array}$ & 31 & 0 & 0.015 & 0.064 & 0.186 & 6 & 3 & 2.03 & 0.89 \\
\hline 21 & Huron River at Rockwood & 04175120 & Chloride (mg/L) & 31 & 0 & 69 & 103 & 174 & 6 & 3 & 4.79 & 0.11 \\
\hline 21 & Huron River at Rockwood & 04175120 & Chromium $(\mu \mathrm{g} / \mathrm{L})$ & 31 & 0 & 0.094 & 0.415 & 1.34 & 6 & 3 & -9.87 & 0.43 \\
\hline 21 & Huron River at Rockwood & 04175120 & Copper $(\mu \mathrm{g} / \mathrm{L})$ & 31 & 0 & 1.03 & 1.59 & 3.63 & 6 & 3 & 3.75 & 0.38 \\
\hline 21 & Huron River at Rockwood & 04175120 & Dissolved oxygen (mg/L) & 31 & 0 & 4.4 & 8 & 14.8 & 6 & 3 & 1.23 & 0.39 \\
\hline
\end{tabular}


Appendix 1. Summary of data collected at select Michigan Water-Chemistry Monitoring Progam stream sites, 1999-2005.-Continued

$\left[\mathrm{mg} / \mathrm{L}\right.$, milligrams per liter; $\mu \mathrm{g} / \mathrm{L}$, micrograms per liter, ng/L, nanograms per liter, $\mu \mathrm{S} / \mathrm{cm}$, microsiemens per centimeter; ${ }^{\circ} \mathrm{C}$, degrees Celsius; USGS, U.S. Geological Survey; N, Nitrogen; P, Phosphorus; NTU, Nephelometric Turbidity Unit; -- , trend not tested]

\begin{tabular}{|c|c|c|c|c|c|c|c|c|c|c|c|c|}
\hline $\begin{array}{l}\text { Watershed } \\
\text { number }\end{array}$ & Site & $\begin{array}{l}\text { USGS } \\
\text { station } \\
\text { number }\end{array}$ & Constituent & $\begin{array}{c}\text { Number } \\
\text { of } \\
\text { samples } \\
\text { collected }\end{array}$ & $\begin{array}{l}\text { Number of } \\
\text { censored } \\
\text { results }\end{array}$ & $\begin{array}{c}\text { Minimum } \\
\text { concen- } \\
\text { tration }\end{array}$ & $\begin{array}{c}\text { Median } \\
\text { concen- } \\
\text { tration }\end{array}$ & $\begin{array}{c}\text { Maximum } \\
\text { concen- } \\
\text { tration }\end{array}$ & $\begin{array}{c}\text { Years } \\
\text { of data } \\
\text { used }\end{array}$ & $\begin{array}{c}\text { Seasons } \\
\text { used }\end{array}$ & $\begin{array}{c}\text { Trend } \\
\text { as a } \\
\text { percent- } \\
\text { age }\end{array}$ & $\begin{array}{c}\text { P-value } \\
\text { of } \\
\text { trend }\end{array}$ \\
\hline 21 & Huron River at Rockwood & 04175120 & Lead $(\mu \mathrm{g} / \mathrm{L})$ & 31 & 0 & 0.475 & 1.46 & 2.84 & 6 & 3 & -0.81 & 0.92 \\
\hline 21 & Huron River at Rockwood & 04175120 & Mercury (ng/L) & 31 & 0 & 0.4 & 1.24 & 4.1 & 6 & 3 & 11.01 & 0.44 \\
\hline 21 & Huron River at Rockwood & 04175120 & Nitrate (mg/L as N) & 31 & 0 & 0.026 & 0.47 & 1.48 & 6 & 3 & -7.60 & 0.46 \\
\hline 21 & Huron River at Rockwood & 04175120 & Nitrite (mg/L as $\mathrm{N})$ & 31 & 0 & 0.005 & 0.011 & 0.037 & 6 & 3 & -4.38 & 0.81 \\
\hline 21 & Huron River at Rockwood & 04175120 & $\mathrm{pH}$ & 31 & 0 & 7 & 7.8 & 8.3 & 6 & 3 & 0.16 & 0.18 \\
\hline 21 & Huron River at Rockwood & 04175120 & Total phosphorus (mg/L as $\mathrm{P}$ ) & 31 & 0 & 0.018 & 0.047 & 0.09 & 6 & 3 & -0.18 & 0.89 \\
\hline 21 & Huron River at Rockwood & 04175120 & Specific conductance $(\mu \mathrm{S} / \mathrm{cm})$ & 31 & 0 & 257 & 905 & 1080 & 6 & 3 & 1.91 & 0.20 \\
\hline 21 & Huron River at Rockwood & 04175120 & $\begin{array}{l}\text { Total Kjehldahl nitrogen } \\
(\mathrm{mg} / \mathrm{L} \text { as } \mathrm{N})\end{array}$ & 31 & 0 & 0.54 & 0.7 & 1.02 & 6 & 3 & 2.00 & 0.71 \\
\hline 21 & Huron River at Rockwood & 04175120 & Total suspended solids (mg/L) & 31 & 0 & 4 & 13 & 175 & 6 & 3 & 1.39 & 0.94 \\
\hline 21 & Huron River at Rockwood & 04175120 & Turbidity (NTU) & 31 & 0 & 3.3 & 8.8 & 37 & 6 & 3 & 0.19 & 1.00 \\
\hline 21 & Huron River at Rockwood & 04175120 & Water temperature $\left({ }^{\circ} \mathrm{C}\right)$ & 31 & 0 & 1.1 & 17.7 & 25.5 & 6 & 3 & 4.21 & 0.69 \\
\hline 22 & River Rouge at River Rouge & 04168550 & $\begin{array}{l}\text { Ammonia } \\
\quad(\mathrm{mg} / \mathrm{L} \text { as } \mathrm{N})\end{array}$ & 47 & 0 & 0.02 & 0.136 & 0.82 & 6 & 3 & 11.61 & 0.25 \\
\hline 22 & River Rouge at River Rouge & 04168550 & Chloride (mg/L) & 47 & 0 & 23 & 68 & 256 & 6 & 3 & 13.40 & 0.33 \\
\hline 22 & River Rouge at River Rouge & 04168550 & Chromium $(\mu \mathrm{g} / \mathrm{L})$ & 47 & 0 & 0.126 & 2.021 & 10.118 & 6 & 3 & -0.26 & 1.00 \\
\hline 22 & River Rouge at River Rouge & 04168550 & Copper $(\mu \mathrm{g} / \mathrm{L})$ & 47 & 0 & 0.793 & 3.2 & 12.698 & 6 & 3 & 8.77 & 0.10 \\
\hline 22 & River Rouge at River Rouge & 04168550 & Dissolved oxygen $(\mathrm{mg} / \mathrm{L})$ & 41 & 0 & 2.4 & 6 & 13.9 & 6 & 3 & -0.15 & 1.00 \\
\hline 22 & River Rouge at River Rouge & 04168550 & Lead $(\mu \mathrm{g} / \mathrm{L})$ & 47 & 0 & 0.112 & 2.249 & 12.356 & 6 & 3 & 3.91 & 0.35 \\
\hline 22 & River Rouge at River Rouge & 04168550 & Mercury (ng/L) & 47 & 0 & 0.4 & 4.667 & 29.584 & 6 & 3 & 8.42 & 0.28 \\
\hline 22 & River Rouge at River Rouge & 04168550 & Nitrate $(\mathrm{mg} / \mathrm{L}$ as $\mathrm{N})$ & 47 & 0 & 0.29 & 0.66 & 1.46 & 6 & 3 & 8.98 & 0.17 \\
\hline 22 & River Rouge at River Rouge & 04168550 & Nitrite $(\mathrm{mg} / \mathrm{L}$ as $\mathrm{N}$ ) & 47 & 0 & 0.003 & 0.023 & 0.057 & 6 & 3 & 13.75 & 0.17 \\
\hline 22 & River Rouge at River Rouge & 04168550 & $\mathrm{pH}$ & 46 & 0 & 6.7 & 7.6 & 8.5 & 6 & 3 & 0.29 & 0.45 \\
\hline 22 & River Rouge at River Rouge & 04168550 & Total phosphorus (mg/L as $\mathrm{P}$ ) & 47 & 0 & 0.009 & 0.079 & 0.42 & 6 & 3 & 11.02 & 0.17 \\
\hline 22 & River Rouge at River Rouge & 04168550 & Specific conductance $(\mu \mathrm{S} / \mathrm{cm})$ & 41 & 0 & 238 & 488 & 1190 & 6 & 3 & 8.22 & 0.34 \\
\hline 22 & River Rouge at River Rouge & 04168550 & $\begin{array}{l}\text { Total Kjehldahl nitrogen } \\
(\mathrm{mg} / \mathrm{L} \text { as } \mathrm{N})\end{array}$ & 47 & 0 & 0.17 & 0.62 & 2 & 6 & 3 & 10.90 & 0.21 \\
\hline 22 & River Rouge at River Rouge & 04168550 & Total suspended solids (mg/L) & 47 & 0 & 1 & 17 & 130 & 6 & 3 & 8.15 & 0.18 \\
\hline 22 & River Rouge at River Rouge & 04168550 & Turbidity (NTU) & 34 & 1 & 1 & 15 & 52 & 6 & 3 & 0.89 & 0.88 \\
\hline 22 & River Rouge at River Rouge & 04168550 & Water temperature $\left({ }^{\circ} \mathrm{C}\right)$ & 47 & 0 & 0.2 & 23.4 & 29 & 6 & 3 & 1.38 & 0.30 \\
\hline
\end{tabular}


Appendix 1. Summary of data collected at select Michigan Water-Chemistry Monitoring Progam stream sites, 1999-2005.-Continued

$\left[\mathrm{mg} / \mathrm{L}\right.$, milligrams per liter; $\mu \mathrm{g} / \mathrm{L}$, micrograms per liter, ng/L, nanograms per liter, $\mu \mathrm{S} / \mathrm{cm}$, microsiemens per centimeter; ${ }^{\circ} \mathrm{C}$, degrees Celsius; USGS, U.S. Geological Survey; N, Nitrogen; P, Phosphorus; NTU, Nephelometric Turbidity Unit; -- , trend not tested]

\begin{tabular}{|c|c|c|c|c|c|c|c|c|c|c|c|c|}
\hline $\begin{array}{l}\text { Watershed } \\
\text { number }\end{array}$ & Site & $\begin{array}{c}\text { USGS } \\
\text { station } \\
\text { number }\end{array}$ & Constituent & $\begin{array}{c}\text { Number } \\
\text { of } \\
\text { samples } \\
\text { collected }\end{array}$ & $\begin{array}{c}\text { Number of } \\
\text { censored } \\
\text { results }\end{array}$ & $\begin{array}{c}\text { Minimum } \\
\text { concen- } \\
\text { tration }\end{array}$ & $\begin{array}{c}\text { Median } \\
\text { concen- } \\
\text { tration }\end{array}$ & $\begin{array}{c}\text { Maximum } \\
\text { concen- } \\
\text { tration }\end{array}$ & $\begin{array}{c}\text { Years } \\
\text { of data } \\
\text { used }\end{array}$ & $\begin{array}{c}\text { Seasons } \\
\text { used }\end{array}$ & $\begin{array}{l}\text { Trend } \\
\text { as a } \\
\text { percent- } \\
\text { age }\end{array}$ & $\begin{array}{c}\text { P-value } \\
\text { of } \\
\text { trend }\end{array}$ \\
\hline 23 & Clinton River at Mt. Clemens & 04165553 & $\begin{array}{l}\text { Ammonia } \\
\quad(\mathrm{mg} / \mathrm{L} \text { as } \mathrm{N})\end{array}$ & 79 & 1 & 0.016 & 0.1 & 0.76 & 6 & 12 & 6.81 & 0.50 \\
\hline 23 & Clinton River at Mt. Clemens & 04165553 & Chloride $(\mathrm{mg} / \mathrm{L})$ & 79 & 0 & 25 & 137 & 447 & 6 & 12 & 4.63 & 0.06 \\
\hline 23 & Clinton River at Mt. Clemens & 04165553 & Chromium $(\mu \mathrm{g} / \mathrm{L})$ & 78 & 0 & 0.45 & 2.12 & 32.739 & 6 & 12 & -8.96 & 0.33 \\
\hline 23 & Clinton River at Mt. Clemens & 04165553 & Copper $(\mu \mathrm{g} / \mathrm{L})$ & 78 & 0 & 1.82 & 3.92 & 40.575 & 6 & 12 & -1.47 & 1.00 \\
\hline 23 & Clinton River at Mt. Clemens & 04165553 & Dissolved oxygen $(\mathrm{mg} / \mathrm{L})$ & 76 & 0 & 2.9 & 7.55 & 14.2 & 6 & 12 & 0.06 & 1.00 \\
\hline 23 & Clinton River at Mt. Clemens & 04165553 & Lead $(\mu \mathrm{g} / \mathrm{L})$ & 78 & 0 & 0.519 & 1.995 & 50.766 & 6 & 12 & 0.98 & 1.00 \\
\hline 23 & Clinton River at Mt. Clemens & 04165553 & Mercury (ng/L) & 78 & 1 & 0.1 & 4 & 106.875 & 6 & 12 & 4.88 & 0.37 \\
\hline 23 & Clinton River at Mt. Clemens & 04165553 & Nitrate $(\mathrm{mg} / \mathrm{L}$ as $\mathrm{N})$ & 79 & 0 & 0.7 & 1.57 & 3.9 & 6 & 12 & -2.57 & 0.05 \\
\hline 23 & Clinton River at Mt. Clemens & 04165553 & Nitrite $(\mathrm{mg} / \mathrm{L}$ as $\mathrm{N})$ & 79 & 0 & 0.012 & 0.039 & 0.106 & 6 & 12 & 10.89 & 0.10 \\
\hline 23 & Clinton River at Mt. Clemens & 04165553 & $\mathrm{pH}$ & 78 & 0 & 6.9 & 7.7 & 8.3 & 6 & 12 & 0.35 & 0.25 \\
\hline 23 & Clinton River at Mt. Clemens & 04165553 & Total phosphorus (mg/L as $\mathrm{P}$ ) & 79 & 0 & 0.05 & 0.174 & 0.87 & 6 & 12 & -3.85 & 0.69 \\
\hline 23 & Clinton River at Mt. Clemens & 04165553 & Specific conductance $(\mu \mathrm{S} / \mathrm{cm})$ & 75 & 0 & 210 & 844 & 1460 & 6 & 12 & 1.55 & 0.48 \\
\hline 23 & Clinton River at Mt. Clemens & 04165553 & $\begin{array}{l}\text { Total Kjehldahl nitrogen } \\
(\mathrm{mg} / \mathrm{L} \text { as } \mathrm{N})\end{array}$ & 79 & 0 & 0.65 & 1.03 & 3.1 & 6 & 12 & 4.55 & 0.09 \\
\hline 23 & Clinton River at Mt. Clemens & 04165553 & Total suspended solids $(\mathrm{mg} / \mathrm{L})$ & 79 & 1 & 4 & 21 & 470 & 6 & 12 & 3.17 & 0.73 \\
\hline 23 & Clinton River at Mt. Clemens & 04165553 & Turbidity (NTU) & 66 & 0 & 2.7 & 19.5 & 310 & 6 & 12 & 1.74 & 0.86 \\
\hline 23 & Clinton River at Mt. Clemens & 04165553 & Water temperature $\left({ }^{\circ} \mathrm{C}\right)$ & 78 & 0 & 0.6 & 15.6 & 25.7 & 6 & 12 & -4.44 & 0.28 \\
\hline 24 & Black River at Port Huron & 04160075 & $\begin{array}{l}\text { Ammonia } \\
\qquad(\mathrm{mg} / \mathrm{L} \text { as } \mathrm{N})\end{array}$ & 23 & 2 & 0.01 & 0.036 & 0.17 & -- & -- & -- & -- \\
\hline 24 & Black River at Port Huron & 04160075 & Chloride $(\mathrm{mg} / \mathrm{L})$ & 23 & 0 & 12 & 28 & 70 & 6 & 3 & 2.35 & 0.43 \\
\hline 24 & Black River at Port Huron & 04160075 & Chromium $(\mu \mathrm{g} / \mathrm{L})$ & 23 & 0 & 0.146 & 0.511 & 1.25 & 6 & 3 & -1.60 & 1.00 \\
\hline 24 & Black River at Port Huron & 04160075 & Copper $(\mu \mathrm{g} / \mathrm{L})$ & 23 & 0 & 1.13 & 2.13 & 4.08 & 6 & 3 & 1.01 & 0.75 \\
\hline 24 & Black River at Port Huron & 04160075 & Dissolved oxygen $(\mathrm{mg} / \mathrm{L})$ & 20 & 0 & 6.76 & 7.7 & 13.1 & 6 & 2 & -0.65 & 0.56 \\
\hline 24 & Black River at Port Huron & 04160075 & Lead $(\mu \mathrm{g} / \mathrm{L})$ & 23 & 0 & 0.218 & 0.559 & 1.66 & 6 & 3 & 2.45 & 0.53 \\
\hline 24 & Black River at Port Huron & 04160075 & Mercury (ng/L) & 23 & 0 & 0.28 & 1.21 & 6.52 & 6 & 3 & 14.13 & 0.32 \\
\hline 24 & Black River at Port Huron & 04160075 & Nitrate $(\mathrm{mg} / \mathrm{L}$ as $\mathrm{N})$ & 23 & 0 & 0.026 & 1.03 & 7.46 & 6 & 3 & -3.35 & 0.76 \\
\hline 24 & Black River at Port Huron & 04160075 & Nitrite $(\mathrm{mg} / \mathrm{L}$ as $\mathrm{N})$ & 23 & 0 & 0.003 & 0.009 & 0.116 & 6 & 3 & 19.88 & 0.09 \\
\hline 24 & Black River at Port Huron & 04160075 & $\mathrm{pH}$ & 21 & 0 & 7.4 & 8 & 8.3 & 6 & 3 & 0.25 & 0.53 \\
\hline 24 & Black River at Port Huron & 04160075 & Total phosphorus (mg/L as P) & 23 & 0 & 0.015 & 0.037 & 0.14 & 6 & 3 & 4.53 & 0.33 \\
\hline 24 & Black River at Port Huron & 04160075 & Specific conductance $(\mu \mathrm{S} / \mathrm{cm})$ & 21 & 0 & 251 & 421 & 740 & 6 & 3 & -1.93 & 0.40 \\
\hline
\end{tabular}


Appendix 1. Summary of data collected at select Michigan Water-Chemistry Monitoring Progam stream sites, 1999-2005.-Continued

$\left[\mathrm{mg} / \mathrm{L}\right.$, milligrams per liter; $\mu \mathrm{g} / \mathrm{L}$, micrograms per liter, ng/L, nanograms per liter, $\mu \mathrm{S} / \mathrm{cm}$, microsiemens per centimeter; ${ }^{\circ} \mathrm{C}$, degrees Celsius; USGS, U.S. Geological Survey; N, Nitrogen; P, Phosphorus; NTU, Nephelometric Turbidity Unit; -- , trend not tested]

\begin{tabular}{|c|c|c|c|c|c|c|c|c|c|c|c|c|}
\hline $\begin{array}{l}\text { Watershed } \\
\text { number }\end{array}$ & Site & $\begin{array}{l}\text { USGS } \\
\text { station } \\
\text { number }\end{array}$ & Constituent & $\begin{array}{c}\text { Number } \\
\text { of } \\
\text { samples } \\
\text { collected }\end{array}$ & $\begin{array}{l}\text { Number of } \\
\text { censored } \\
\text { results }\end{array}$ & $\begin{array}{c}\text { Minimum } \\
\text { concen- } \\
\text { tration }\end{array}$ & $\begin{array}{c}\text { Median } \\
\text { concen- } \\
\text { tration }\end{array}$ & $\begin{array}{l}\text { Maximum } \\
\text { concen- } \\
\text { tration }\end{array}$ & $\begin{array}{c}\text { Years } \\
\text { of data } \\
\text { used }\end{array}$ & $\begin{array}{c}\text { Seasons } \\
\text { used }\end{array}$ & $\begin{array}{l}\text { Trend } \\
\text { as a } \\
\text { percent- } \\
\text { age }\end{array}$ & $\begin{array}{c}\text { P-value } \\
\text { of } \\
\text { trend }\end{array}$ \\
\hline 24 & Black River at Port Huron & 04160075 & $\begin{array}{l}\text { Total Kjehldahl nitrogen } \\
(\mathrm{mg} / \mathrm{L} \text { as } \mathrm{N})\end{array}$ & 23 & 0 & 0.2 & 0.59 & 1.27 & 6 & 3 & -0.97 & 0.91 \\
\hline 24 & Black River at Port Huron & 04160075 & Total suspended solids (mg/L) & 23 & 1 & 4 & 13 & 38 & 6 & 3 & 6.90 & 0.51 \\
\hline 24 & Black River at Port Huron & 04160075 & Turbidity (NTU) & 23 & 0 & 4.1 & 12 & 46 & 6 & 3 & 7.95 & 0.47 \\
\hline 24 & Black River at Port Huron & 04160075 & Water temperature $\left({ }^{\circ} \mathrm{C}\right)$ & 21 & 0 & 1.6 & 15.9 & 25.9 & 6 & 3 & 8.75 & 0.14 \\
\hline 25 & Flint River near Fosters & 04149000 & $\begin{array}{l}\text { Ammonia } \\
\quad(\mathrm{mg} / \mathrm{L} \text { as } \mathrm{N})\end{array}$ & 31 & 4 & 0.01 & 0.05 & 0.93 & -- & -- & -- & -- \\
\hline 25 & Flint River near Fosters & 04149000 & Chloride (mg/L) & 31 & 0 & 54 & 90 & 232 & 6 & 3 & 2.05 & 0.71 \\
\hline 25 & Flint River near Fosters & 04149000 & Chromium $(\mu \mathrm{g} / \mathrm{L})$ & 31 & 0 & 0.438 & 1.24 & 7.58 & 6 & 3 & -12.75 & 0.28 \\
\hline 25 & Flint River near Fosters & 04149000 & Copper $(\mu \mathrm{g} / \mathrm{L})$ & 31 & 0 & 1.77 & 2.93 & 13.5 & 6 & 3 & -5.56 & 0.48 \\
\hline 25 & Flint River near Fosters & 04149000 & Dissolved oxygen (mg/L) & 30 & 0 & 7 & 8.56 & 13.2 & 6 & 2 & 1.47 & 0.47 \\
\hline 25 & Flint River near Fosters & 04149000 & Lead $(\mu \mathrm{g} / \mathrm{L})$ & 31 & 0 & 0.568 & 1.81 & 16.9 & 6 & 3 & -12.03 & 0.34 \\
\hline 25 & Flint River near Fosters & 04149000 & Mercury (ng/L) & 31 & 0 & 0.76 & 3.69 & 29.71 & 6 & 3 & -5.40 & 0.56 \\
\hline 25 & Flint River near Fosters & 04149000 & Nitrate (mg/L as N) & 31 & 0 & 0.62 & 2.3 & 5.8 & 6 & 3 & -1.77 & 0.37 \\
\hline 25 & Flint River near Fosters & 04149000 & Nitrite (mg/L as N) & 31 & 0 & 0.009 & 0.024 & 0.061 & 6 & 3 & -5.33 & 0.69 \\
\hline 25 & Flint River near Fosters & 04149000 & $\mathrm{pH}$ & 31 & 0 & 7.5 & 8 & 8.7 & 6 & 3 & -0.10 & 1.00 \\
\hline 25 & Flint River near Fosters & 04149000 & Total phosphorus (mg/L as $\mathrm{P}$ ) & 31 & 0 & 0.055 & 0.152 & 0.73 & 6 & 3 & -11.31 & 0.53 \\
\hline 25 & Flint River near Fosters & 04149000 & Specific conductance $(\mu \mathrm{S} / \mathrm{cm})$ & 31 & 0 & 511 & 724 & 957 & 6 & 3 & -1.22 & 0.30 \\
\hline 25 & Flint River near Fosters & 04149000 & $\begin{array}{l}\text { Total Kjehldahl nitrogen } \\
(\mathrm{mg} / \mathrm{L} \text { as } \mathrm{N})\end{array}$ & 31 & 0 & 0.73 & 1.1 & 4.5 & 6 & 3 & -9.17 & 0.16 \\
\hline 25 & Flint River near Fosters & 04149000 & Total suspended solids (mg/L) & 31 & 2 & 4 & 29 & 290 & 6 & 3 & -14.67 & 0.45 \\
\hline 25 & Flint River near Fosters & 04149000 & Turbidity (NTU) & 31 & 0 & 4.6 & 18 & 180 & 6 & 3 & -24.12 & 0.12 \\
\hline 25 & Flint River near Fosters & 04149000 & Water temperature $\left({ }^{\circ} \mathrm{C}\right)$ & 31 & 0 & 0.1 & 18.1 & 26.1 & 6 & 3 & 4.94 & 0.37 \\
\hline 26 & Cass River near Bridgeport & 04152002 & $\begin{array}{l}\text { Ammonia } \\
\qquad(\mathrm{mg} / \mathrm{L} \text { as } \mathrm{N})\end{array}$ & 31 & 5 & 0.01 & 0.025 & 0.5 & -- & -- & -- & -- \\
\hline 26 & Cass River near Bridgeport & 04152002 & Chloride (mg/L) & 31 & 0 & 20 & 46 & 88 & 6 & 3 & 1.48 & 0.42 \\
\hline 26 & Cass River near Bridgeport & 04152002 & Chromium $(\mu \mathrm{g} / \mathrm{L})$ & 31 & 0 & 0.187 & 0.82 & 2.07 & 6 & 3 & -3.38 & 0.62 \\
\hline 26 & Cass River near Bridgeport & 04152002 & Copper $(\mu \mathrm{g} / \mathrm{L})$ & 31 & 0 & 1.15 & 2.06 & 2.94 & 6 & 3 & 5.24 & 0.18 \\
\hline 26 & Cass River near Bridgeport & 04152002 & Dissolved oxygen (mg/L) & 29 & 0 & 5.6 & 8.6 & 12 & 6 & 2 & 1.04 & 0.76 \\
\hline 26 & Cass River near Bridgeport & 04152002 & Lead $(\mu \mathrm{g} / \mathrm{L})$ & 31 & 0 & 0.435 & 0.689 & 2.39 & 6 & 3 & 3.80 & 0.27 \\
\hline 26 & Cass River near Bridgeport & 04152002 & Mercury (ng/L) & 31 & 0 & 1.06 & 2.06 & 5.74 & 6 & 3 & 9.65 & 0.34 \\
\hline 26 & Cass River near Bridgeport & 04152002 & Nitrate (mg/L as N) & 31 & 0 & 0.161 & 1.86 & 7.1 & 6 & 3 & -4.23 & 0.67 \\
\hline
\end{tabular}


Appendix 1. Summary of data collected at select Michigan Water-Chemistry Monitoring Progam stream sites, 1999-2005.-Continued $\left[\mathrm{mg} / \mathrm{L}\right.$, milligrams per liter; $\mu \mathrm{g} / \mathrm{L}$, micrograms per liter, ng/L, nanograms per liter, $\mu \mathrm{S} / \mathrm{cm}$, microsiemens per centimeter; ${ }^{\circ} \mathrm{C}$, degrees Celsius; USGS, U.S. Geological Survey; N, Nitrogen; P, Phosphorus; NTU, Nephelometric Turbidity Unit; -- , trend not tested]

\begin{tabular}{|c|c|c|c|c|c|c|c|c|c|c|c|c|}
\hline $\begin{array}{l}\text { Watershed } \\
\text { number }\end{array}$ & Site & $\begin{array}{l}\text { USGS } \\
\text { station } \\
\text { number }\end{array}$ & Constituent & $\begin{array}{c}\text { Number } \\
\text { of } \\
\text { samples } \\
\text { collected }\end{array}$ & $\begin{array}{l}\text { Number of } \\
\text { censored } \\
\text { results }\end{array}$ & $\begin{array}{c}\text { Minimum } \\
\text { concen- } \\
\text { tration }\end{array}$ & $\begin{array}{c}\text { Median } \\
\text { concen- } \\
\text { tration }\end{array}$ & $\begin{array}{c}\text { Maximum } \\
\text { concen- } \\
\text { tration }\end{array}$ & $\begin{array}{c}\text { Years } \\
\text { of data } \\
\text { used }\end{array}$ & $\begin{array}{l}\text { Seasons } \\
\text { used }\end{array}$ & $\begin{array}{l}\text { Trend } \\
\text { as a } \\
\text { percent- } \\
\text { age }\end{array}$ & $\begin{array}{c}\text { P-value } \\
\text { of } \\
\text { trend }\end{array}$ \\
\hline 26 & Cass River near Bridgeport & 04152002 & Nitrite (mg/L as N) & 31 & 0 & 0.005 & 0.02 & 0.047 & 6 & 3 & 2.61 & 0.47 \\
\hline 26 & Cass River near Bridgeport & 04152002 & $\mathrm{pH}$ & 30 & 0 & 7.23 & 7.95 & 8.4 & 6 & 3 & 0.06 & 0.46 \\
\hline 26 & Cass River near Bridgeport & 04152002 & Total phosphorus (mg/L as $\mathrm{P}$ ) & 31 & 0 & 0.042 & 0.08 & 0.2 & 6 & 3 & 2.13 & 0.85 \\
\hline 26 & Cass River near Bridgeport & 04152002 & Specific conductance $(\mu \mathrm{S} / \mathrm{cm})$ & 31 & 0 & 403 & 682 & 800 & 6 & 3 & -0.33 & 0.64 \\
\hline 26 & Cass River near Bridgeport & 04152002 & $\begin{array}{l}\text { Total Kjehldahl nitrogen } \\
(\mathrm{mg} / \mathrm{L} \text { as } \mathrm{N})\end{array}$ & 31 & 0 & 0.51 & 0.95 & 1.16 & 6 & 3 & -3.31 & 0.12 \\
\hline 26 & Cass River near Bridgeport & 04152002 & Total suspended solids (mg/L) & 31 & 0 & 7 & 28 & 63 & 6 & 3 & 10.82 & 0.34 \\
\hline 26 & Cass River near Bridgeport & 04152002 & Turbidity (NTU) & 31 & 0 & 10 & 24 & 62 & 6 & 3 & -0.25 & 1.00 \\
\hline 26 & Cass River near Bridgeport & 04152002 & Water temperature $\left({ }^{\circ} \mathrm{C}\right)$ & 31 & 1 & 0 & 15.1 & 27 & 6 & 3 & 3.80 & 0.43 \\
\hline 27 & Shiawassee River near Fergus & 04145000 & $\begin{array}{l}\text { Ammonia } \\
\qquad(\mathrm{mg} / \mathrm{L} \text { as } \mathrm{N})\end{array}$ & 34 & 1 & 0.007 & 0.0305 & 0.25 & 6 & 6 & -18.65 & 0.04 \\
\hline 27 & Shiawassee River near Fergus & 04145000 & Chloride (mg/L) & 34 & 0 & 33 & 69 & 117 & 6 & 6 & 3.76 & 0.10 \\
\hline 27 & Shiawassee River near Fergus & 04145000 & Chromium $(\mu \mathrm{g} / \mathrm{L})$ & 34 & 0 & 0.132 & 0.534 & 2.7 & 6 & 6 & -16.18 & 0.05 \\
\hline 27 & Shiawassee River near Fergus & 04145000 & Copper $(\mu \mathrm{g} / \mathrm{L})$ & 34 & 0 & 1.15 & 1.765 & 3.48 & 6 & 6 & -0.60 & 0.71 \\
\hline 27 & Shiawassee River near Fergus & 04145000 & Dissolved oxygen (mg/L) & 34 & 0 & 6 & 8.5 & 13.6 & 6 & 6 & 0.74 & 0.57 \\
\hline 27 & Shiawassee River near Fergus & 04145000 & Lead $(\mu \mathrm{g} / \mathrm{L})$ & 34 & 0 & 0.191 & 0.674 & 2.38 & 6 & 6 & -8.57 & 0.06 \\
\hline 27 & Shiawassee River near Fergus & 04145000 & Mercury (ng/L) & 34 & 0 & 0.59 & 1.875 & 5.33 & 6 & 6 & -2.59 & 1.00 \\
\hline 27 & Shiawassee River near Fergus & 04145000 & Nitrate (mg/L as N) & 34 & 0 & 0.181 & 0.695 & 2.5 & 6 & 6 & -5.50 & 0.45 \\
\hline 27 & Shiawassee River near Fergus & 04145000 & Nitrite $(\mathrm{mg} / \mathrm{L}$ as $\mathrm{N})$ & 34 & 0 & 0.004 & 0.01 & 0.048 & 6 & 6 & -2.59 & 0.84 \\
\hline 27 & Shiawassee River near Fergus & 04145000 & $\mathrm{pH}$ & 34 & 0 & 7.6 & 8.015 & 8.5 & 6 & 6 & 0.89 & 0.05 \\
\hline 27 & Shiawassee River near Fergus & 04145000 & Total phosphorus (mg/L as $\mathrm{P}$ ) & 34 & 0 & 0.024 & 0.063 & 0.177 & 6 & 6 & -3.02 & 0.73 \\
\hline 27 & Shiawassee River near Fergus & 04145000 & Specific conductance $(\mu \mathrm{S} / \mathrm{cm})$ & 34 & 0 & 463 & 674 & 816 & 6 & 6 & 0.59 & 0.57 \\
\hline 27 & Shiawassee River near Fergus & 04145000 & $\begin{array}{l}\text { Total Kjehldahl nitrogen } \\
(\mathrm{mg} / \mathrm{L} \text { as } \mathrm{N})\end{array}$ & 34 & 0 & 0.52 & 0.685 & 1.35 & 6 & 6 & -1.17 & 0.66 \\
\hline 27 & Shiawassee River near Fergus & 04145000 & Total suspended solids $(\mathrm{mg} / \mathrm{L})$ & 34 & 4 & 4 & 17.5 & 72 & -- & -- & -- & -- \\
\hline 27 & Shiawassee River near Fergus & 04145000 & Turbidity (NTU) & 34 & 0 & 1.6 & 10 & 38 & 6 & 6 & -16.31 & 0.05 \\
\hline 27 & Shiawassee River near Fergus & 04145000 & Water temperature $\left({ }^{\circ} \mathrm{C}\right)$ & 34 & 0 & 0.2 & 18.2 & 26.9 & 6 & 6 & -1.97 & 0.66 \\
\hline 28 & Tittabawassee River near Saginaw & 04156510 & $\begin{array}{l}\text { Ammonia } \\
\quad(\mathrm{mg} / \mathrm{L} \text { as } \mathrm{N})\end{array}$ & 31 & 0 & 0.023 & 0.071 & 0.28 & 6 & 3 & -5.88 & 0.35 \\
\hline 28 & Tittabawassee River near Saginaw & 04156510 & Chloride (mg/L) & 31 & 0 & 30 & 85 & 204 & 6 & 3 & -0.44 & 0.90 \\
\hline 28 & Tittabawassee River near Saginaw & 04156510 & Chromium $(\mu \mathrm{g} / \mathrm{L})$ & 31 & 0 & 0.057 & 0.47 & 2.25 & 6 & 3 & -9.64 & 0.27 \\
\hline 28 & Tittabawassee River near Saginaw & 04156510 & Copper $(\mu \mathrm{g} / \mathrm{L})$ & 31 & 0 & 1.24 & 1.69 & 2.75 & 6 & 3 & 1.69 & 0.89 \\
\hline
\end{tabular}


Appendix 1. Summary of data collected at select Michigan Water-Chemistry Monitoring Progam stream sites, 1999-2005.—Continued

$\left[\mathrm{mg} / \mathrm{L}\right.$, milligrams per liter; $\mu \mathrm{g} / \mathrm{L}$, micrograms per liter, $\mathrm{ng} / \mathrm{L}$, nanograms per liter, $\mu \mathrm{S} / \mathrm{cm}$, microsiemens per centimeter; ${ }^{\circ} \mathrm{C}$, degrees Celsius; USGS, U.S. Geological Survey; N, Nitrogen; P, Phosphorus; NTU, Nephelometric Turbidity Unit; --, trend not tested]

\begin{tabular}{|c|c|c|c|c|c|c|c|c|c|c|c|c|}
\hline $\begin{array}{l}\text { Watershed } \\
\text { number }\end{array}$ & Site & $\begin{array}{l}\text { USGS } \\
\text { station } \\
\text { number }\end{array}$ & Constituent & $\begin{array}{c}\text { Number } \\
\text { of } \\
\text { samples } \\
\text { collected }\end{array}$ & $\begin{array}{l}\text { Number of } \\
\text { censored } \\
\text { results }\end{array}$ & $\begin{array}{c}\text { Minimum } \\
\text { concen- } \\
\text { tration }\end{array}$ & $\begin{array}{l}\text { Median } \\
\text { concen- } \\
\text { tration }\end{array}$ & $\begin{array}{c}\text { Maximum } \\
\text { concen- } \\
\text { tration }\end{array}$ & $\begin{array}{c}\text { Years } \\
\text { of data } \\
\text { used }\end{array}$ & $\begin{array}{c}\text { Seasons } \\
\text { used }\end{array}$ & $\begin{array}{l}\text { Trend } \\
\text { as a } \\
\text { percent- } \\
\text { age }\end{array}$ & $\begin{array}{c}\text { P-value } \\
\text { of } \\
\text { trend }\end{array}$ \\
\hline 28 & Tittabawassee River near Saginaw & 04156510 & Dissolved oxygen (mg/L) & 30 & 0 & 6.2 & 8.7 & 12.6 & 6 & 2 & 4.97 & 0.15 \\
\hline 28 & Tittabawassee River near Saginaw & 04156510 & Lead $(\mu \mathrm{g} / \mathrm{L})$ & 31 & 0 & 0.11 & 0.425 & 2.53 & 6 & 3 & -4.85 & 0.55 \\
\hline 28 & Tittabawassee River near Saginaw & 04156510 & Mercury (ng/L) & 31 & 0 & 0.48 & 1.86 & 6.95 & 6 & 3 & 0.41 & 0.89 \\
\hline 28 & Tittabawassee River near Saginaw & 04156510 & Nitrate (mg/L as N) & 31 & 0 & 0.24 & 0.74 & 3.17 & 6 & 3 & -2.86 & 0.92 \\
\hline 28 & Tittabawassee River near Saginaw & 04156510 & Nitrite $(\mathrm{mg} / \mathrm{L}$ as $\mathrm{N})$ & 31 & 1 & 0.008 & 0.017 & 0.039 & 6 & 3 & 6.76 & 0.45 \\
\hline 28 & Tittabawassee River near Saginaw & 04156510 & $\mathrm{pH}$ & 31 & 0 & 7.3 & 8 & 8.2 & 6 & 3 & -0.02 & 0.88 \\
\hline 28 & Tittabawassee River near Saginaw & 04156510 & Total phosphorus (mg/L as $\mathrm{P}$ ) & 31 & 0 & 0.03 & 0.057 & 0.149 & 6 & 3 & -7.23 & 0.05 \\
\hline 28 & Tittabawassee River near Saginaw & 04156510 & Specific conductance $(\mu \mathrm{S} / \mathrm{cm})$ & 31 & 0 & 377 & 633 & 1052 & 6 & 3 & -1.74 & 0.09 \\
\hline 28 & Tittabawassee River near Saginaw & 04156510 & $\begin{array}{l}\text { Total Kjehldahl nitrogen } \\
\quad(\mathrm{mg} / \mathrm{L} \text { as } \mathrm{N})\end{array}$ & 31 & 0 & 0.5 & 0.77 & 1.02 & 6 & 3 & -3.73 & 0.03 \\
\hline 28 & Tittabawassee River near Saginaw & 04156510 & Total suspended solids (mg/L) & 31 & 2 & 4 & 16 & 91 & 6 & 3 & -14.88 & 0.26 \\
\hline 28 & Tittabawassee River near Saginaw & 04156510 & Turbidity (NTU) & 31 & 1 & 1 & 8 & 63 & 6 & 3 & -16.27 & 0.04 \\
\hline 28 & Tittabawassee River near Saginaw & 04156510 & Water temperature $\left({ }^{\circ} \mathrm{C}\right)$ & 31 & 1 & 0 & 15.2 & 27.3 & 6 & 3 & 14.07 & 0.16 \\
\hline 30 & Au Sable River near Au Sable & 04137500 & $\begin{array}{l}\text { Ammonia } \\
\quad(\mathrm{mg} / \mathrm{L} \text { as } \mathrm{N})\end{array}$ & 75 & 0 & 0.002 & 0.014 & 0.031 & 6 & 12 & -3.69 & 0.14 \\
\hline 30 & Au Sable River near Au Sable & 04137500 & Chloride (mg/L) & 77 & 0 & 5 & 6 & 34 & 6 & 12 & 0.00 & 0.22 \\
\hline 30 & Au Sable River near Au Sable & 04137500 & Chromium $(\mu \mathrm{g} / \mathrm{L})$ & 77 & 33 & 0.001 & 0.057 & 0.884 & -- & -- & -- & -- \\
\hline 30 & Au Sable River near Au Sable & 04137500 & Copper $(\mu \mathrm{g} / \mathrm{L})$ & 77 & 0 & 0.106 & 0.225 & 0.588 & 6 & 12 & 14.11 & 0.09 \\
\hline 30 & Au Sable River near Au Sable & 04137500 & Dissolved oxygen (mg/L) & 74 & 0 & 7.1 & 8.7 & 13.1 & 6 & 12 & -1.07 & 0.52 \\
\hline 30 & Au Sable River near Au Sable & 04137500 & Lead $(\mu \mathrm{g} / \mathrm{L})$ & 77 & 0 & 0.0193 & 0.0386 & 0.121 & 6 & 12 & -1.90 & 0.48 \\
\hline 30 & Au Sable River near Au Sable & 04137500 & Mercury (ng/L) & 77 & 2 & 0.01 & 0.28 & 4.579 & 6 & 12 & 10.76 & 0.18 \\
\hline 30 & Au Sable River near Au Sable & 04137500 & Nitrate $(\mathrm{mg} / \mathrm{L}$ as $\mathrm{N})$ & 74 & 2 & 0.001 & 0.011 & 0.151 & 6 & 12 & -5.47 & 0.22 \\
\hline 30 & Au Sable River near Au Sable & 04137500 & Nitrite (mg/L as N) & 76 & 1 & 0.001 & 0.002 & 0.005 & 6 & 12 & -0.02 & 0.05 \\
\hline 30 & Au Sable River near Au Sable & 04137500 & $\mathrm{pH}$ & 76 & 0 & 7.3 & 7.95 & 8.7 & 6 & 12 & 0.28 & 0.48 \\
\hline 30 & Au Sable River near Au Sable & 04137500 & Total phosphorus (mg/L as $\mathrm{P}$ ) & 77 & 0 & 0.001 & 0.01 & 0.019 & 6 & 12 & -0.56 & 1.00 \\
\hline 30 & Au Sable River near Au Sable & 04137500 & Specific conductance $(\mu \mathrm{S} / \mathrm{cm})$ & 74 & 0 & 253 & 295 & 747 & 6 & 12 & 0.67 & 0.20 \\
\hline 30 & Au Sable River near Au Sable & 04137500 & $\begin{array}{l}\text { Total Kjehldahl nitrogen } \\
(\mathrm{mg} / \mathrm{L} \text { as } \mathrm{N})\end{array}$ & 77 & 0 & 0.009 & 0.19 & 0.37 & 6 & 12 & 1.07 & 0.44 \\
\hline 30 & Au Sable River near Au Sable & 04137500 & Total suspended solids (mg/L) & 76 & 66 & 1 & 4 & 20 & -- & -- & -- & -- \\
\hline 30 & Au Sable River near Au Sable & 04137500 & Turbidity (NTU) & 65 & 62 & 0.4 & 1 & 1 & -- & -- & -- & -- \\
\hline 30 & Au Sable River near Au Sable & 04137500 & Water temperature $\left({ }^{\circ} \mathrm{C}\right)$ & 77 & 0 & 0.7 & 17.5 & 25.9 & 6 & 12 & 1.84 & 0.55 \\
\hline
\end{tabular}



